\title{
Geothermal
}

\section{Progress Monitor}

\section{5}

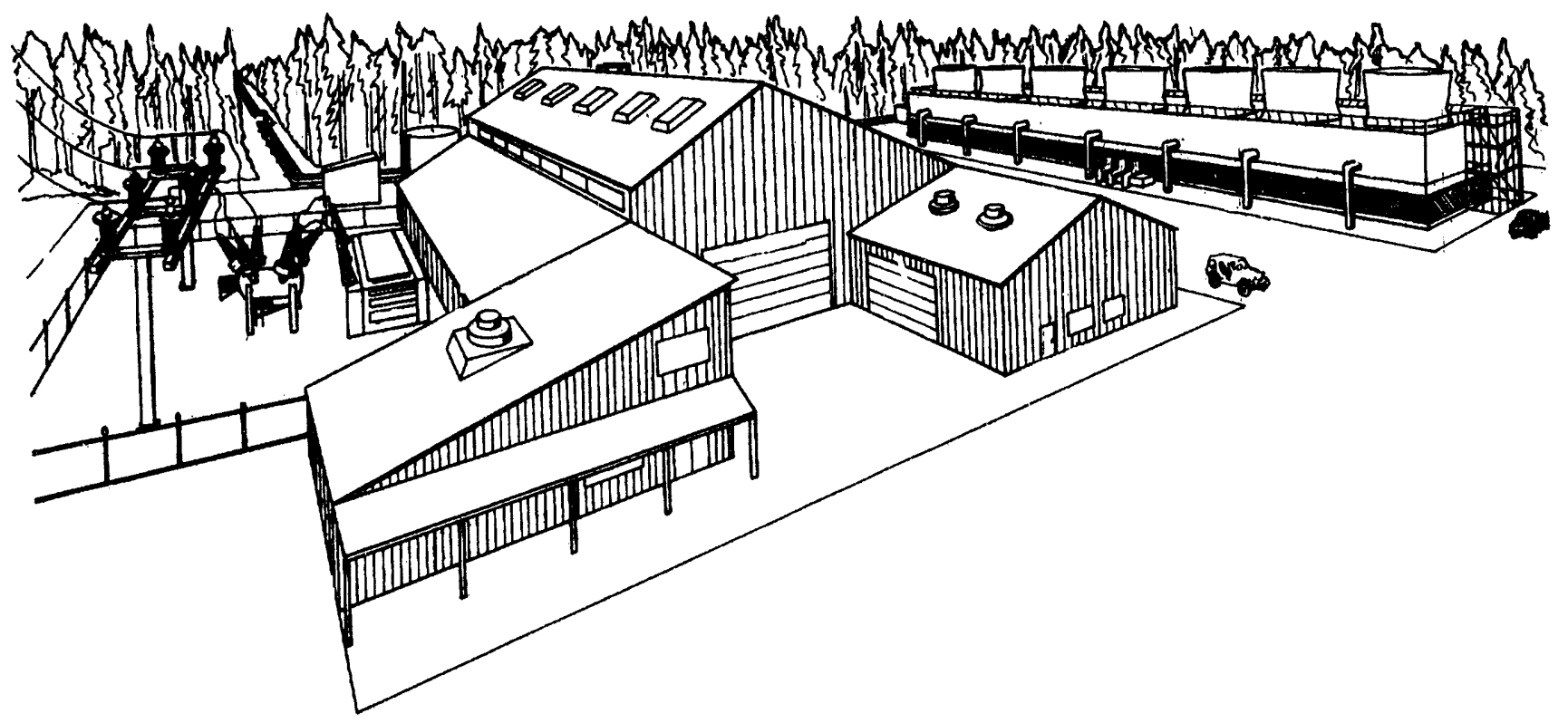

\section{December 1993}

\section{U.S. Department of Energy}

Assistant Secretary for Energy Efficiency and Renewable Energy

Geothermal Division 
This report can be obtained from the

U.S. Department of Energy

Office of Scientific and Technical Information

P.O. Box 62

Oak Ridge, Tennessee 37831 


\section{Geothermal \\ Progress Monitor \\ Report No.15}

\section{December 1993}

\section{U.S. Department of Energy}

Assistant Secretary for Energy Efficiency and Renewable Energy

Geothermal Division

Washington, DC 20585

Prepared in Cooperation with the Interagency Geothermal Coordinating Council with the Assistance of DynCorp $\bullet$ Meridian Corporation, Alexandria, Virginia 
Introduction ......... 1

The Federal Beat $\ldots \ldots \ldots .3$

The Industry Scene $\ldots \ldots 17$

Financing $\ldots \ldots \ldots \ldots 23$

Development Status . . . . 25

Leasing and Drilling . . . . 43

State and Local . . . . . . . 51

International $\ldots \ldots \ldots \ldots 57$

Technology Transfer . . . . . 63

Directory . . . . . . . . 79

ILLUSTRATION: Artist's rendering of the first geothermal power plant in the Pacific Northwest. Sponsored by the California Energy Co., Inc., and the Eugene Water \& Electric Board, the Newberry Geothermal Pilot Project is part of the Bonneville Power Administration's Resource Supply Expansion Program. 
Two themes dominate this issue of the Geothermal Progress Monitor, the 15th since its inception in 1980. The first of these is the significance of the government/industry partnership role in geothermal development. This joint effort is reflected in the continued, measured growth in the use of geothermal energy, for both power generation and direct use applications, in this country and abroad, as well as in the development of new, innovative technologies to ensure a bright future for the resource. The second theme is the growing popularity of geothermal heat pumps (GHPs) among utilities, their customers, and federal agencies, all with disparate interests in the technology.

In DEVELOPMENT STATUS, the U.S. industry's announced plans to add nearly $700 \mathrm{MWe}$ of geothermal electric capacity through the year 2000 are itemized by location. An interesting feature of this development is that eight of the 22 new plants will open up seven previously undeveloped sites.

The U.S. geothermal industry is also investing in the governmental programs of several other countries to expand their geothermal power capacity -- e.g., Indonesia, the Philippines, Costa Rica, and Nicaragua. The INTERNATIONAL section also describes new geothermal exploration and development projects in Greece, Japan, New Zealand, and Poland along with the introduction of binary technology in Italy. A World Geothermal Conference to be held in Florence in 1995 will be sponsored by Italian interests, the International Geothermal Association, and the U.S.-based, industry-oriented Geothermal Resources Council.

Dissipation of clouds on the horizon of existing U.S. geothermal power plants is being addressed on two fronts. The
INDUSTRY SCENE indicates the willingness of the California Public Utility Commission to ameliorate the anticipated reduction in revenue of geothermal plant operators at the end of the initial 10-year high-income period of the Interim Standard Offer 4 (ISO 4 ) contracts which were designed to promote early geothermal development. Six potential policy alternatives that CPUC could consider if the viability of some projects is threatened are offered, such as contract renegotiation to levelize payments for a certain number of years.

Innovative solutions to productivity problems are being sought at The Geysers where most of the plants pre-date the ISO4 concept. A consortium of local, state, and federal agencies and industry are funding the 26-mile Southeast Geysers Effluent Pipeline and Injection Project to bring treated wastewater from nearby communities to the field for injection. Injection has been used successfully at The Geysers and other geothermal areas as an effective sustainable resource management practice. DOE is also cost-sharing with industry a research program at the site (see FEDERAL BEAT) to acquire the information necessary for improved forecasts of future reservoir performance and to investigate the effectiveness of tracers in determining the long-term impact of injection on well production.

Technology development, planned or underway, through joint government/ industry cooperation range from those needed to increase the known geothermal resource data base, to reduce the costs of exploration, and to accelerate the availability of higher-efficiency, lower-cost geothermal power generation. In the first instance, plans are under consideration for a new industry-coupled geothermal exploratory drilling project designed to confirm suspected, but as yet undelineated 
reservoirs. New resource supplies are essential if geothermal energy is to meet its projected potential.

Evaluation of reservoirs at reduced cost is the objective of a project to investigate the viability of slimhole drilling as a means to satisfy the requirements of the investment community before incurring the high costs of production-size exploratory wells. Major reductions in the upfront capital costs of geothermal projects will greatly increase their competitiveness with conventional power generation.

Other efforts to seek overall improvement in drilling technology are the focus of a National Advanced Drilling and Excavation Project, which coordinates the interests of several industries, federal agencies, and academia. The National Research Council has also been enlisted by DOE to study revolutionary advances in fundamental rock drilling technologies.

The government/industry partnership is also supporting experimental projects to test new, innovative energy conversion systems using geothermal energy with the potential for greater efficiency in the power plants of the future. DOE, a consortium of western utilities, and the Electric Power Research Institute are jointly funding a project to design the "next generation" geothermal power plant. DOE is also sharing with industry the cost of two projects to demonstrate technologies in their first application in hot water geothermal power plants. One is the "Kalina cycle" for use in binary plants, and the other is the Biphase turbine that is expected to increase greatly the output of existing flash steam plants.

The fact that geothermal heat pumps are attracting a wide circle of proponents is documented almost throughout this issue of GPM. Current users indicate, in two separate surveys, their appreciation of the high efficiency and low operating costs of the system; 97 percent would buy it again, and 99 percent would recommend it to others. Utilities are seeking the benefits afforded by GHPs through reduced peak demand and higher annual load factors by offering various incentives to customers to offset the upfront installation costs.

Two federal agencies view the use of GHPs as supportive of their particular missions. The Environmental Protection Agency has concluded that GHPs create the lowest level of power plant carbon dioxide emissions in most regions of the country and reduce refrigerant use -- of concern in atmospheric ozone depletion -by over 50 percent compared to air source heat pumps. The Department of Defense has concluded, as enunciated in a military handbook on energy use, that the GHP is "the most efficient method of using electric power for heating." Thus, DOD has embarked on a program to accelerate the installation of GHPs at its facilities "to contribute to modernization and energy efficiency by reducing power consumption and maintenance costs.

The importance of geothermal direct use applications was underscored by the GRC special achievement award to the Geo-Heat Center at the Oregon Institute of Technology. The award recognizes the Center's efforts in developing "practical, hands-on," cost-effective techniques for harnessing geothermal resources, location and development research, and economic and practical assistance to those interested in geothermal direct use. GRC also noted that the Center's staff "has become internationally recognized as the leading source of information on direct use." 


\section{DOE RESTRUCTURED; CLEAN ENERGY SOURCES EMPHASIZED}

In April 1993 the new Secretary of Energy Hazel R. O'Leary announced "a restructuring of the Department of Energy to achieve the Clinton Administration's energy, environmental, and economic objectives for a changing world...The restructuring," she said, "will focus the agency to develop clean energy sources to meet the needs of the economy while protecting the environment and transfer technologies from our labs to the private sector to enhance U.S. competitiveness." The restructuring is designed to reflect the principal programmatic missions of the Department: energy programs; weapons/ waste clean-up programs; and science and technology programs.

The Energy Programs mission area, directed by Deputy Secretary of Energy William White, brings together the energy supply and demand programs under a single management cluster. Its mission responsibility encompasses departmental energy research, development, and demonstration programs that have nearterm application. Its objectives include increasing the use of natural gas and renewable energy technologies, reducing reliance on foreign oil, and providing leadership in global climate protection activities. It will coordinate with other Department programs such as the Science and Technology mission area, which will emphasize development and transfer of innovative, clean, and efficient energy technologies into domestic and international markets.
Under Energy Programs, the former Office of the Assistant Secretary for Conservation and Renewable Energy is retitled Assistant Secretary for Energy Efficiency and Renewable Energy. Although its renewable energy role is unchanged, "conservation has not gone out of style," according to Allan R. Hoffman, Associate Deputy Assistant Secretary, Office of Utility Technologies. "The new title," he added, "is simply one of the more visible changes reflecting the Department's new direction."

Under Science and Technology Programs, functions related to laboratory management policy and coordination are transferred to the new Office of Laboratory Management, and functions related to university and science education programs are transferred to the new Office of Science Education and Technical Information. The latter office will centralize responsibility for management coordination and oversight of the collection and dissemination of information resulting from the Department's R\&D activities and the development and implementation of departmental policy for university and science education programs.

The diverse national laboratories, Hoffman said, "have made immeasurable contributions to the nation's security, technological advancements, and energy supplies during the Cold War era. They now offer research capabilities with a redefined mission: developing innovative energy technologies; supporting the transfer of new technology to U.S. industry... and conducting basic research." In addition, it is expected that the labs will help develop environmentally beneficial 
"green" technologies and support advanced science, math, and engineering education.

The organization of the Office of Energy Efficiency and Renewable Energy (EE) has not changed. It is arranged around the four principal energy users -- utilities, industry, transportation, and buildings -- as well as a technical and financial assistance arm. According to Hoffman, this orientation toward energy users, has helped the technology development program focus on addressing the needs of the marketplace. The Geothermal Division is still found in the Office of Renewable Energy Conversion, a part of the Office of Utility Technologies.

In concluding his address prepared for DOE's Program Raview XI (see article below), Hoffman stated: "In the 1990s, with a renewed emphasis on cooperation with industry on meeting near-term priority needs, the Department is moving actively to reinvigorate existing ties with industry groups, such as the Geothermal Drilling Organization and Geothermal Technology Organization, and establishing new ones, such as the cooperative slimhole drilling coring effort and industry-coupled drilling."

\section{GEOTHERMAL PROGRAM REVIEW XI EMPHASIZES ENVIRONMENTAL ROLE OF THE RESOURCE}

\%\$\% \% \% \% \% \%

Addressing the theme of DOE's Geothermal Program Review XI -"Geothermal Energy -- the Environmentally Responsible Energy Technology for the 90s" -- Dr. John E. Mock concluded that the entire geothermal community should undertake to inform decision-makers and the public on geothermal's documented environmental performance. "All of us," he said, "government, the involved scientists and engineers, and industry ownership/management have a responsibility to inform those who regulate us, compete with us, and buy from us to make our voices heard."

Mock, Director of DOE's Geothermal Division, noted that geothermal has riot always been considered an environmental "plus." In 1970, with passage of the Geothermal Steam Act, this resource was described as a virtually "pollution-free" power source. Subsequent perceptions, however, labeled the steam at The Geysers a source of "dangerous" air contaminants, and hot water plant development raised questions on solids content and naturally occurring radiation. Now, Lake County, which embraces a large portion of Geysers development, is the only area in California to be cited for full compliance with the state's stringent Clean Air Act standards. And, working together, regulators and the hot water industry have managed to achieve a balance of environmental protection and freedom to use the resource economically.

Today, because of the documented performance of the resource in comparison to the polluting potential of fossil fuels and their land use requirements, the pendulum has come full swing to the perception of geothermal energy as an environmentally preferable and responsible source of energy. The consensus of views of a number of cognizant Federal and state agencies presented by Mock reported "good behavior" in the environmental performance of geothermal operators, and 
no incidents of noncompliance could be reported.

Mock noted, however, "while enjoying this well-deserved good reputation, we must remain eternally vigilant and mindful that continued incident-free performance is paramount to our future."

(Program Review XI was held April 27-28, 1993, at Berkeley, California. Summaries of or excerpts from various papers presented are found in several sections of this GPM.)

\section{LABORATORY TESTS ACHIEVE MORE THAN 80 PERCENT REMOVAL OF TOXIC METALS FROM GEOTHERMAL WASTES}

An ongoing R\&D program at the Brookhaven National Laboratory (BNL) has identified technologies for low-cost, environmentally acceptable disposal of toxic geothermal residues. Using a prototype laboratory-scale pilot plant for detoxification processing, better than an 80 percent removal of toxic metals is achieved in short periods. The fast rates of metal removal, with residence time in the bioreactor of four to 25 hours, have been achieved at $\mathrm{pH} 1-2$ and temperatures of $55-60^{\circ} \mathrm{C} \quad\left(131-140^{\circ} \mathrm{F}\right)$. A secondary biochemical process for the removal of trace radionuclides, particularly radium, is currently being developed and tested. A complementary process for concentration of metals from the process byproducts (i.e., the aqueous phase) produces a water effluent that meets drinking water standards.
The bioprocesses investigated are based on biochemical solubilization of metals, and of the technologies investigated, current experience indicates that fluidized bed and agitated tank bioreactors generate comparable results in terms of their usefulness and efficiency. Nevertheless, considering practical constraints of space availability, construction, and operating costs, the agitated tank bioreactor was chosen as the pilot plant operating unit.

The application of this technology for the treatment of residual geothermal sludges has economic and environmental advantages. First, either these sludges are produced in large quantities (i.e., tons), but contain only small amounts (i.e., parts per million) of the material that would subject the entire waste to environmental regulation, or the value of the materials would make their recovery advantageous. in such circumstances, conventional technologies for decontamination and/or recovery are usually not suitable because of technical, economic, and environmental constraints. Second, the disposal costs of untreated sludges are increasing, and the space for their disposal is decreasing.

Moreover, the long-term liability associated with these wastes is becoming a factor.

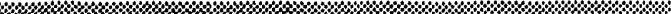 \\ DOE/INDUSTRY CONTINUE TO SEEK SOLUTIONS TO RESERVOIR PROBLEMS AT THE GEYSERS}

The DOE/Industry Geysers Research Program, initiated in 1990 at the request of 


\section{Biochemical Waste Treatment Plant Using Agitated Tank Bioreactor}

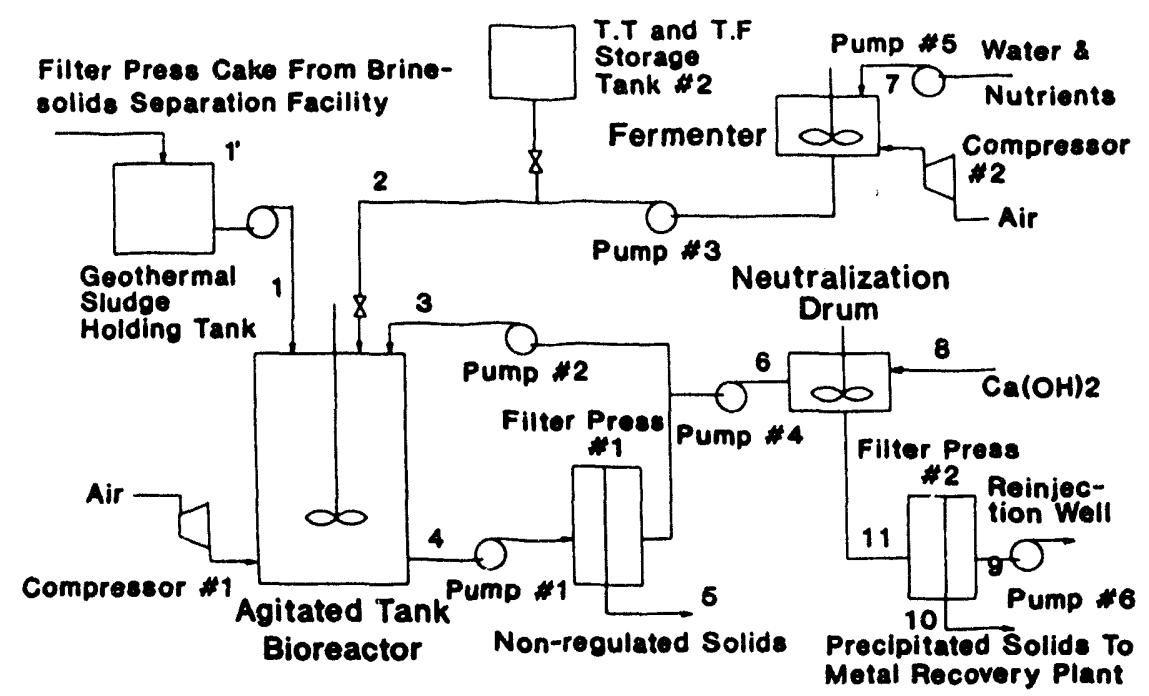

This pilot plant contains three 50-gallon agitated tank bioreactors that serve as a bacterial culture reservoir, mixing and processing reactor, and a neutralization unit for concentration and subsequent metal and water recovery. The current system is made of polyethylene and glass components that utilize commercially available pumps, filters, controls, and other accessories with minor modifications.

utilities and field operators at the site, is continuing its search for solutions to the following problems occurring after 30 years of commercial production of the field:

- higher than anticipated declines in productivity and reservoir pressure

- increased production of highly corrosive hydrochloric acid $(\mathrm{HCl})$

- increase in noncondensible gases.

These problems have reduced the output of 24 power generating units with a total design capacity of 1,800 MWe to a level of about 1,250 MWe. These plants and attendant steam production and injection facilities represent an industry investment of about $\$ 3.5$ billion since the 1950 s, an investment that has saved the equivalent of 200 million barrels of oil. DOE joined industry in the effort to find means to mitigate the effects of the reservoir decline so that more of the over 95 percent of the heat estimated to remain in the rocks can continue to be recovered as a reliable energy source.

As reported in GPM Issue No. 14, the research program participants have been divided into working groups to provide a synergistic effect to propel the research forward and encourage communication 
among researchers. Each group is composed of six to 12 members of similar disciplines and mutual involvement in various aspects of the work at The Geysers. The four groups are:

- Field Geological and Geochemical Modeling

- Injection Technologies

- Reservoir Performance Prediction

- Power Generation, Pipelines, Injection Water, and Corrosion Control

These divisions reflect the consensus that the most profitable areas of pursuit include improvements in power plants to increase efficiency and improvements in injection technology as a means of boosting steam production, as well as obtaining more water to be used for injection. Because the limited resources available precluded working on all contributing elements of these objectives at once, three projects were selected for initiation in Fiscal Year 1993. They are:

- A deep investigative well in the central Geysers region to acquire the information necessary to achieve improved forecasts of future reservoir performance. It is planned to rotary drill this well to the top of the cap rock at about 4,500 feet, and then continuously core to a depth of at least 9,000 feet. This approach will provide a continuous sampling of the total lithologic section present.
Continuing the well to 12,000 feet will characterize the reservoir section to the present limits of development. Deepening the well to 15,000 feet will reach the maximum suspected reservoir depth (based or seismic data), while testing for a high-temperature reservoir in the area. The estimated cost is nearly $\$ 2$ million.

- An injection test in the most heavily developed southeastern section of the field. Earlier industry tests showed that certain wells in the area were highly responsive to shallow well injection, and the results of subsequent tracer tests were encouraging, showing the practicality of using multiple tracers in an area simultaneously. The current project involves sampling of steam produced after tracers are injected and analytical determination of tracer concentrations over a three-year period from Unocal, Northern California Power Agency, and Calpine wells that may be affected.

Seismic monitoring of the area in a near real-time mode will be conducted to guide steam sampling and operations during the test. Concurrently, steam production and pressure response in the wells in the area will be evaluated. Total cost of the three-year project, cofunded by DOE and industry, is estimated at $\$ 1.08$ million. 
- Field-wide physical and chemical property maps. Industry will provide the basic reservoir data and cooperate with DOE-funded researchers to develop both historic and current field-wide maps. Industry will prioritize features to be covered that could include information such as isobaric contours, downhole to surface enthalpy and superheat, permeability, isotopic. noncondensible gases, microseismic occurrences, reservoir fractures, and injection-derived steam. DOE will fund the $\$ 40,000$ cost, with industry supplying technical personnel to help DOE researchers copy and evaluate data from company files.

\section{USE OF GEOTHERMAL HEAT PUMPS BEING EVALUATED}

As part of the DOE-funded program to promote accelerated development of lowand moderate-temperature geothermal resources, an evaluation of the use of geothermal heat pumps (GHPs) in residential and commercial applications is in progress. Information is being collected and interpreted to delineate:

- the most effective and successful utility marketing and incentive programs to expand GHP markets

- the benefit to utilities from reduced peak demand and higher annual load factors
- barriers to market entry

- potential total national energy savings contribution from GHP's

- suitability of GHPs for northern climates.

Energy-use patterns are being documented before and after installation of GHPs in typical residential and commercial situations along with energy savings and life-cycle costs. Preliminary conclusions from the study indicate that GHP technology is effective in saving energy over all other electrical heating systems, typically on the order of 15 to 35 percent over air-source systems and 25 to 60 percent over electrical systems. Compared with nonelectric heating systems, the GHP was found to save significant energy costs over liquefied petroleum gas (LPG) .- on the order of 35 to 58 percent -- but has very small to no savings over natural gas systems. On the other hand, an eastern utility, the Northern Virginia Electric Cooperative (NOVEC), has found that GHPs "are less expensive to operate than even the most efficient natural gas or propane system" (Current Living, October 1993).

The low-temperature assessment study sponsored by DOE found that due to the additional cost of the ground loop, the economic payback of the system requires, in most cases, an incentive to be attractive and, in other instances, there is no economic justification. However, according to NOVEC, the cost will be recouped in seven years "because the geothermal will cut your heating and cooling bill in half. On an average house, it will save $\$ 1,000$ a year." 
In addition, since utilities (based on contacts with nearly 60 of them) view geothermal heat pumps as a demand-side management (DSM) tool for reducing peak load requirements, many of them offer incentives of some kind. These incentives may include rebates of $\$ 125$ to $\$ 500$ per ton of installed capacity, low cost loans, discounts on electric rates for the heat pump system, and, in some cases, installation of ground-coupled closed loops. Heat pumps are often seen as a means of retaining customers with all-electric homes built in the 1960s to early 1970s who are now tempted to switch to cheaper natural gas.

A preliminary performance analysis has been evaluated for two ground-coupled heat pump (GCHP) residential systems in Minnesota from data obtained from United Power Association, Elk River, MN. Data were collected on an hourly basis, monitoring ground loop supply and return temperatures, outside air temperature, compressor power, circulating pump power, and water heater power.

Both systems experienced lower peak demand and lower annual heating and cooling energy requirements than an air source heat pump, although it was demonstrated that a better performance can be expected with a vertical groundcoupled heat pump than with a horizontal configuration. The annual savings in the residence with the vertical application was 11 percent for cooling and 34 percent for heating.

According to a survey published by the national Rural Electric Cooperative Association, "Consumers like geothermal units. In fact, 97 percent of the present geothermal users would buy the system again, and 99 percent would recommend one to a friend."

The three principal participants in the low-temperature assessment program are the Geo-Heat Center at the Oregon Institute of Technology, University of Utah Research Institute, and the Idaho Water Resources Research Institute.

\section{PLANS FOR NEW DOE/INDUSTRY COST-SHARED EXPLORATORY DRILLING IN PROGRESS}

$\$ \% \% \% \% \% \%$

Plans are being developed for initiation of a new industry-coupled, geothermal exploratory drilling project. A similar joint effort conducted in the late 1970s was notably successful, with eight of the 14 sites explored in commercial production today.

This means, however, that the most favorable sites identified by that effort have been developed, and if the production of electricity from geothermal energy is to expand significantly, additional defined resources are needed. Although DOE's Energy Information Administration estimates that geothermal capacity could nearly quadruple over the next 20 years, this growth could be seriously impeded without Federal sharing of the costs and risks of delineating new prospects for development.

Two million dollars are budgeted for DOE's initial contribution to the new initiative for which industry partners will be 
solicited through the Idaho National Engineering Laboratory. INEL is responsible for the technical and operational management of the Geothermal Division's Reservoir Technology Research.

Bidding will be open to all interested U.S. parties with the option of proposing core or production-size holes. Bidders will be expected to describe their prospect areas, including the types of information gathered so far (such as surface geology or shallow heat flow). In addition, plans as to how a prospect will be utilized must be discussed; that is, by a utility or by an independent producer in competition in the open market.

Other DOE research directed toward reducing the costs of geothermal exploration is described in LEASING AND DRILLING.

\section{DEMONSTRATIONS OF IMPROVED GEOTHERMAL POWER GENERATION TECHNOLOGY SELECTED}

In August 1993, two proposals in response to a DOE solicitation were selected for negotiation of three-year cooperative agreements for demonstration of the economic benefits of improved electrical power generating systems in geothermal applications. Exergy, Inc., of Hayward, California, will design and build a 12 MWe "Kalina cycle" power plant in Steamboat Springs, Nevada, and Douglas Energy Co. of Placentia, California, will integrate a "Biphase turbine" into an existing geothermal system at Coso Hot Springs, California. The total estimated costs of these projects are $\$ 44,914,651$ of which the DOE cost share will be approximately 20 percent.

The Kalina "KCS11" design for a geothermal binary plant is one of a family of cycles that are applicable over a wide range of temperatures and typically feature a highly recuperative cycle using a mixture of water and ammonia as the working fluid. The KCS11 cycle to be used in this demonstration is somewhat different from other Kalina cycles in that it will use aircooled condensers and will not vary the composition of the working fluid throughout the power cycle. Operating pressures are kept subcritical as a maximum and above atmospheric as a minimum. The efficiency of the plant design described in a paper titled "Application of the Kalina Cycle Technology to Geothermal Power Generation" in the GRC Transactions for 1989 is calculated to be nearly 70 percent.

The Biphase turbine is expected to increase the power output of an existing flash steam geothermal power plant by about 30 percent using the same well flow. (See related article in INDUSTRY SCENE regarding Calpine's acquisition of certain rights to the biphase technology.) The installation by Douglas Energy, owner of the Biphase Co., in the Far West plant at Steamboat Springs will mark the first commercial geothermal use of a Biphase turbine although the technology was tested successfully at the Utah Power \& Light geothermal power plant several years ago. 


\section{BRINE MODEL CALCULATIONS COMPARE WELL WITH LABORATORY AND FIELD DATA; NEXT USER'S WOKK.SHOP PLANNED FOR SPRING OF ' 94}

Since each geothermal reservoir is unique, their varying characteristics must be evaluated -- first, to estimate the economic viability of any given reservoir for power production, and then, to predict the behavior of the reservoir under production conditions in order to avoid costly problems associated with brine chemistry. Traditionally, such problems have been identified either from actual plant production experience or from laboratory simulations. Now, however, highly reliable thermodynamic models of brine chemistry for use by the geothermal community have been developed with DOE support by the chemistry department of the University of California at San Diego. The many uses of brine simulation models are summarized in the following table.

\begin{tabular}{|c|c|}
\hline Exploration & $\begin{array}{l}\text { Predict Scale Formation } \\
\text { Predict Gas Behavior } \\
\text { Determine Formation Water } \\
\text { Characteristics } \\
\text { Predict Recoverable Energy } \\
\text { Predict History and Evolution of Resource }\end{array}$ \\
\hline Plant Design and Operation & $\begin{array}{l}\text { Predict Scale Formation } \\
\text { Predict Phase Separation } \\
\text { Simulate Chemical Treatments } \\
\text { Test Energy Optimization Strategies } \\
\text { Test Ways to Minimize Operations Costs } \\
\text { Support Laboratory Simulations }\end{array}$ \\
\hline Waste Treatment & $\begin{array}{l}\text { Simulate Mineral Recovery Strategies } \\
\text { Predict Environmental Hazards } \\
\text { Simulate Reinjection Strategies }\end{array}$ \\
\hline
\end{tabular}

The capabilities of the present models include:

- Predict Behavior of Calcium Carbonate Scale Formation in $\mathrm{NaCl}$ and $\mathrm{CaCl}_{2}$ Brines for $\mathrm{T}=0$ to $250^{\circ} \mathrm{C}$ ( $\mathrm{PC}$ version available)
- Predict Solubility of $\mathrm{CO}_{2}$ and $\mathrm{CH}_{4}$ in $\mathrm{NaCl}$ Brines for $\mathrm{T}=0$ to $250^{\circ} \mathrm{C}$ (PC version available)

- Predict Solubility of Amorphous Silica Scale in Brines for $T=0$ to $250^{\circ} \mathrm{C}$ 
- Predict Solubilities of Scaling Minerals (Gypsum, Anhydrite, etc.) to $250^{\circ} \mathrm{C}$

- Calculate Precipitation Characteristics of Rock-Water Systems Containing $\mathrm{Na}, \mathrm{K}, \mathrm{Ca}, \mathrm{Mg}$, $\mathrm{Cl}$, and $\mathrm{SO}_{4}$ for $\mathrm{T}=0$ to $250^{\circ} \mathrm{C}$

- Predict Onset of Two Phase Behavior (Gas Breakout) in $\mathrm{NaCl}$ Brines

- Predict Solubility of Hydrogen Sulfide $\left(\mathrm{H}_{2} \mathrm{O}-\mathrm{H}_{2} \mathrm{~S}-\mathrm{HS}-\right)$ System $(0$ to $90^{\circ} \mathrm{C}$; 0 in 60 bars)

- Predict Partial Fugacity in Mixed Gas System $\left(\mathrm{CO}_{2}-\mathrm{CH}_{4}-\mathrm{H}_{2} \mathrm{O}\right) \mathrm{T}=0$ to $1000^{\circ} \mathrm{C}$ and $\mathrm{P}=0$ to 1000 bars

- Predict Gas-Liquid Equilibrium in the $\mathrm{CO}_{2}-\mathrm{CH}_{4}-\mathrm{H}_{2} \mathrm{O}$ System

The model calculations compare remarkably well with both laboratory and field data, and the models typically retain the reliability of the experimental data on which they are based. Model development is continuing to complete a comprehensive brine model that will, for example, predict scaling (gypsum-anhydrite, carbonate, silica, metal sulfides) and acid-base characteristics in the system.

As new or expanded models are developed, they are included in a userfriendly application package called GEOTHERM, which can be loaded from diskettes to PCs or Macintosh computers. An annual workshop is held in the use of these programs to meet specific needs. The next User's Workshop is planned for the spring of 1994. Information may be obtained from:

John Weare

University of California, San Diego

Dept. of Chemistry, 0340

9500 Gilman Drive

La Jolla, CA $92093-0342$

Phone: $\quad$ (707) $545-7600$

Fax: $\quad$ (707) $544-6855$

$\$ \% \$ \% \% \% \% \% \% \% \% \% \% \% \% \% \% \% \% \% \% \% \% \% \% \% \%$

MILITARY LOOKING TO GHP FOR MAJOR ENERGY COST SAVINGS

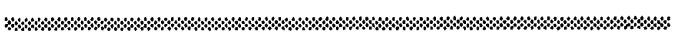

The Department of Defense is seeking to save $\$ 25$ to $\$ 50$ million annually in electric power costs by accelerating the installation of geothermal heat pumps at DoD facilities. The objective of the new Strategic Environmental Research and Development Program (SERDP) -- to contribute to modernization and energy efficiency by reducing power consumption and maintenance costs -- is guided by Chapter 10 of Military Handbook 1190, which states: "The most efficient method of using electric power for heating is the water-source heat pump (GHP)."

SERDP will install GHP systems in at least six DoD sites using its funds to pay up to 100 percent of the incremental costs over traditional heating, ventilating, and air conditioning (HVAC) systems. DoD bases or facilities with high energy costs (exceeding $\$ 0.06 / \mathrm{kWh}$ equivalent) will be evaluated for GHP application. A smaller number will be chosen for more detailed examination and design. Both residential and other buildings will be considered, as 
well as constructing new systems or retrofiting of existing systems.

A second task will consist of training DoD staff, assistance in design of systems, and obtaining utility incentives or other options for reducing the up-front installation costs. A third task will incorporate technical assistance during GHP installation at selected :jites, monitoring and documenting energy use (including peak load characteristics of the GHPs), documenting maintenance costs before and after system installation, and preparing a final report for DOE la participant in the program) and DoD, including the GHP Test Bed Demonstration irogram for DoD, conducted by the Pacific Northwest Laboratory.

The point of contact for SERDP is Lew Pratsch of DOE's Geothermal Division.

\section{DRAMATIC INCREASE IN \\ HDR RESERVOIR PRODUCTION \\ OCCURS AT END OF CURTAILED \\ FLOW TEST; COMMERCIAL INTEREST IN HDR SOUGHT}

The principal objective of the recent flow testing of the Phase II hot dry rock (HDR) reservoir at Fenton Hill, New Mexico, was to demonstrate its long-term viability as a significant source of thermal energy. Although the length of the tests was curtailed by funding constraints, promising results were obtained, and during the last phase of flow testing, a sudden and very large increase occurred in reservoir production. Scientists at Los Alamos National Laboratory, where the
HDR concept originated, declared that the increase "is the most profound change in reservoir production ever experienced in the HDR project at Los Alamos."

Two periods of steady-state reservoir flow testing were conducted: 16 weeks from April through July 1992, and eight weeks from February through April 1993. These were conducted at an aseismic injection pressure of about 3,960 psi -- not high enough to extend the dimensions of the man-made reservoir -- and a production well backpressure of 1,400 psi. Testing in the interim between these two major phases included a six-week flow test at a much lower injection pressure and a twomonth test with the injection pressure at 3,960 psi, but at even higher levels of production well backpressure -- 1,800 and 2,200 psi.

Major results from these tests include:

- No thermal drawdown of the reservoir was observed.

- Water consumption reached stable levels as low as seven percent of the injected fluid, a remarkably low water loss considering the very large volume of fractured rock comprising the reservoir.

- More than a six-fold excess of thermal energy was produced, and a potential for a 50 percent excess production of electricity was indicated even at thermal-to-electric conversion rates of only 10 percent. (The cost data upon which these conclusions are based included electricity and fuel oil to run the 
plant only; there is currently no realistic way to document labor, maintenance, capital, and other incidental costs in the same manner as the fuel and electric costs.)

- Suspended solids in the circulating fluid were nil, and dissolved solids were very low $(3,000-4,000 \mathrm{ppm})$.

- Dissolved gases consisted primarily of $\mathrm{CO}_{2}$ and totaled less than 3,000 ppm.

- There were no emissions to the environment during closed loop operations except for waste heat.

In early May 1993, during the final phase of testing, a sudden and very large increase in production occurred, with the flow rate increasing by almost 48 percent in less than one minute, and the production temperature increasing by about $6^{\circ} \mathrm{C}\left(11^{\circ} \mathrm{F}\right)$ to over $190^{\circ} \mathrm{C}\left(374^{\circ} \mathrm{F}\right)$. The sudden change in reservoir flow impedance appeared to be the result of pressure cycling, but furiding constraints precluded investigation of the causes of the reduction.

The above results may favorably affect the major factors in the technical and economic feasibility of HDR operation -maintenance of sufficiently high temperatures and flow rates to support commercial utilization of the resource and minimal surface water requirements, especially in water-short regions. However, although thess results are encouraging, they are not definitive, and the stage is now set for an initiative led by private industry to take HDR technology from its current state of scientific and engineering demonstration to the
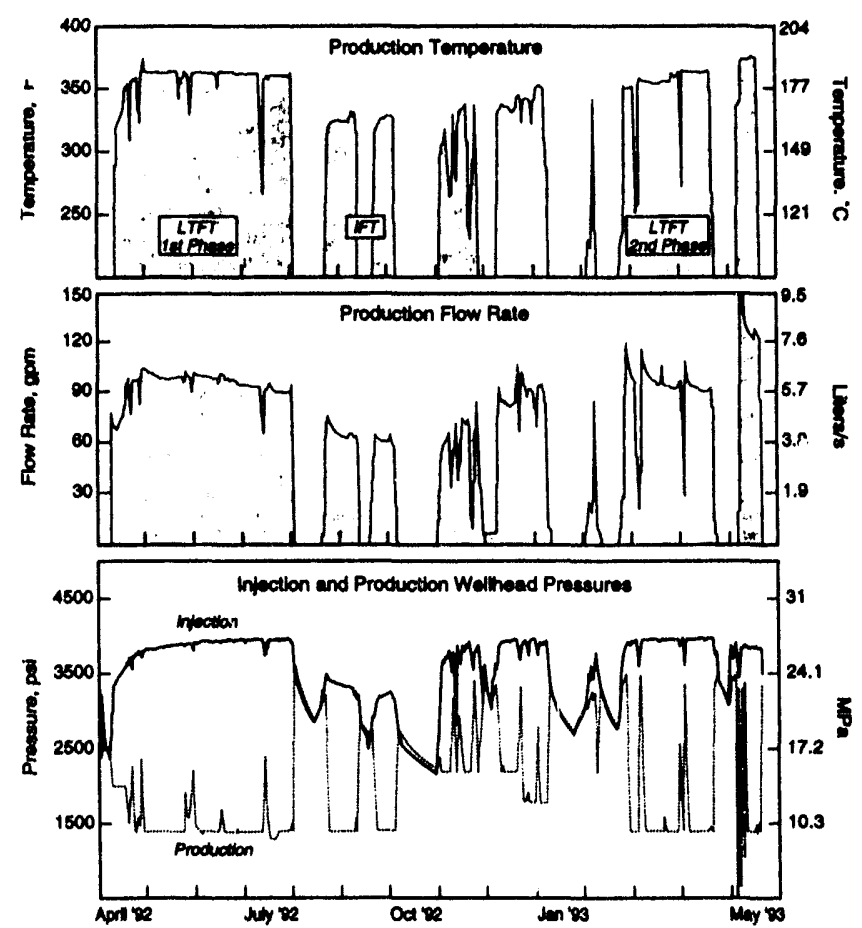

Recent Production Testing of the Fenton Hill Reservoir 
production and marketing of energy in commercial quantities. Because of the technology risks involved, this can probably be accomplished only through a costshared industry/government effort.

The potential rewards are considered to be great. "Heat mining," as HDR technology is becoming known, represents an opportunity for geothermal energy to continue to be a major competitor among the clean and renewable energy sources into the 21 st century and beyond since it removes most of the regional barriers associated with other geothermal forms.

To this end, DOE has formally sought interest (Commerce Business Daily), from industrial concerns to develop a facility to produce and market electric power or thermal energy from geothermal hot dry rock resources. Evaluation of expressions of interest is not expected before publication of this issue of GPM.

\section{WORKSHOPS LOOK AT PROSPECTS FOR HOT DRY ROCK TECHNOLOGY}

Two workshops on hot dry rock were held in Philadelphia in January 1993. The potential of HDR resources for the U.S. electric power industry was discussed at a workshop sponsored by the Electric Power Research Institute (EPRI) and hosted by the Philadelphia Electric Company. In compliance with the Energy Policy Act (EPAct), a companion workshop, cosponsored by the U.S. Geological Survey and DOE, reviewed the potential of HDR resources in the eastern United States.
Speakers at both meetings were drawn from a cross-section of industry, government, and academic circles with interests in energy research, development, and utilization. There appeared to be a general consensus on the potential of HDR, but differing viewpoints on the timeframe in which this potential may be realized.

For the USGS/DOE discussions, the "eastern United States" was defined as the eastern half of the contiguous U.S., an area bounded by the western margin of the Great Plains and the Atlantic Ocean. No thermal anomalies within this area are attributable to young-to-contemporary volcanic or other igneous activity; most are in areas of relatively high natural radiogenic heat production in crystalline basement rocks blanketed by sediments of low thermal conductivity, or above areas of water heated deeper in the crust. Temperatures of potential heat mining sites would rarely exceed $150^{\circ} \mathrm{C}\left(300^{\circ} \mathrm{F}\right)$ at depths of 13,000 feet in the east.

Based on the existing limited data set, the most promising areas of interest (top of crystalline basement at depths of less than 13,000 feet) are in:

- Western New York

- Northwestern Pennsylvania

- Delmarva Peninsula of Delaware, Maryland, and Virginia

- Northern Nebraska

- Southern South Dakota 
- Along the Wisconsin-Illinois border

- Northwestern Louisiana

The areas of interest expand considerably, it was noted, if the target temperatures are lower, say 60 to $80^{\circ} \mathrm{C}$ (140 to $180^{\circ} \mathrm{F}$ ).

In addressing the potential HDR market in the eastern segment of the country, it was noted that relatively modest increases in energy costs or increased demand for hydrocarbon forms of energy could create a significant market for direct-use HDR applications, particularly for residential and institutional heating and cooling. When applying an economic analysis specifically to the eastern U.S., however, well depths required for a given temperature are much greater than in the west, with a consequent increase in the cost. It was concluded, therefore, that bringing the price of HDR-generated electricity into the competitive realm for temperature gradients typical of the east will be heavily dependent on dramatic improvements in drilling technology to lower well costs. It was also pointed out that a central and as yet unanswered question is whether HDR (man-made) reservoirs can be engineered to meet the economic design criteria (see above article) or whether the earth's natural properties limit the range of working conditions to less than the design goals.

A report on the Congressionally mandated workshop on HDR in the east is in publication by USGS with collaboration by DOE. Its major recommendations will include 1) a number of steps to greatly enlarge the limited database currently available to enhance resource evaluation and assessment, and 2) technology development including extending the Fenton Hill reservoir experiments, selecting a prototype HDR site in the east, and increasing government-industry joint research on advanced drilling technologies.

The preliminary summary of the report notes that the one-day workshop attendees represented "a broad spectrum of expertise and opinion and included skeptics of HDR technology as well as fervent advocates." In addition, "The report attempts to provide a balanced view of the proceedings. The conclusions and recommendations represent a majority view, if not a strict consensus of those attending."

The EPRI Workshop was introduced by former Rep. Kostmayer of Pennsylvania, who had also introduced the amendment to EPAct calling for the USGS/DOE session. 


\section{CPUC PROJECTS "MODERATE" IM- PACT OF END OF FIXED PRICES ON GEOTHERMAL INDUSTRY}

In a report prepared for the California Public Utilities Commission, it is estimated that the end of the 10-year fixed-price period of Interim Standard Offer 4 (ISO4) contracts "will probably only have a moderate effect on the geothermal industry." These contracts were developed to encourage the growth of independent power producers by providing the opportunity for a substantial profit from electricity sold to utilities over the initial 10-year period. After this period, however energy prices revert to the short-run avoided cost (SRAC) of the purchasing utility, or the cost a utility avoids by purchasing power from independent producers. The SRAC is based primarily on fuel prices and is expected to be far below the fixed, forecasted prices specified in the ISO 4 contracts for the initial 10 years, thus causing many producers to experience substantial revenue reductions when the latter expire.

However, the CPUC projections indicate a less drastic impact on geothermal power producers than for some other alternative energy facilities -- e.g., cogeneration and biomass, estimating that "the larger (geothermal) projects should be able to cover their operation and maintenance and other overhead costs, but may not be able to finance the same level of capital expenditures." The geothermal industry analysis relies solely on data from Magma Power Co. and California Energy Co., the two publicly owned companies that dominate the industry. Based on these two companies alone, the report notes that "the geothermal industry appears relatively healthy at present [since] Magma and CEC received rates of return on common equity of 16 percent and 27 percent, respectively, in 1991." It was also noted, again based on the audited financial statements of these two publicly held companies, that "few companies should have debt service payments much beyond the end of the fixed-price period." In sum, 28 geothermal projects will be affected, representing 90 percent of total installed capacity.

For some of these projects, the 10-year period will begin to expire in the mid1990s, although for the newer plants the term runs until 1999 or 2000 . The CPUC report concludes that "oil and gas-fired cogenerators could sustain revenue reductions approaching 200 percent and other (producers) could sustain revenue reductions approaching 60 percent." These numbers are called "illustrative" reductions, however, and it is stated that "when compared with 1991 revenue, the reductions are much less dramatic. Oil and gas-fired cogenerators would sustain revenue reductions of about seven percent, and the others would exceed 40 percent."

The report enumerates six potential policy alternatives that CPUC could consider if the viability of sorne projects is threatened, including letting present trends coritinue. However, the report recommends that the Commission encourage contract renegotiation as long as ratepayer benefits are ensured. Renegotiation could involve 1) levelizing 
payments of the last portion of the fixedprice period and for up to five years after the 11 th year when SRAC payments are received, and 2) levelizing payments for a certain number of years after the end of the fixed-price period to ensure a consistent payment stream. One advantage of the first option, the report notes, is that it would work to keep utility prices down, since utilities may have to pay up to $15.6 \mathrm{c} / \mathrm{kWh}$ as the producers approach the end of the fixed-price period.

This article was drawn from the portion of the CPUC report printed in the March 1993 issue of the Geothermal Resources Council Bulletin. The Bulletin notes that the full report can be obtained by calling the CPUC Division of Rate Payer Advocates, Energy Resources Branch, at (415) 703-3089.

The report refers to the affected independent power producers as "qualifying facilities," or OFs, reflecting their status under the Public Utilities Regulatory Policy Act (PURPA). This Act requires utilities to purcinase the output of power generation facilities that meet certain specified qualifications.

\section{UNOCAL COMPLETES SALE OF IMPERIAL VALLEY, GLASS MOUNTAIN GEOTHERMAL ASSETS}

Unocal Corp. (Los Angeles, California) announced on March 31, 1993, that its operating subsidiary, Union Oil Co. of California, has completed the sale of its geothermal operations in California's Imperial Valley, as well as the sale of its
Glass Mountain/Medicine Lake geothermal properties in northern California.

Unocal's Imperial Valley geothermal operations, along with other domestic exploratory geothermal assets, were sold to Magma Power Co. for $\$ 225$ million plus working capital. Unocal could also receive up to $\$ 15$ million in contingent payments from Magma based on the addition of new power generating capacity and on a one percent royalty on the revenues from such additions. (See related article below.)

Magma received all leases and assets related to Unocal's Imperial Valley operations. This includes three power generating facilities with a combined capacity of $80 \mathrm{MWe}$, and about 43,000 net acres of geothermal leases and fee properties. In addition, Unocal will be assigning geothermal leases in prospect areas referred to as Long Valley, California, and Blue Clay and New York Canyon, Nevada, to Magma.

In a separate sale, Unocal assigned all its interests (approximately 61 percent) in the 41,000-plus acre Glass Mountain/Medicine Lake Federal Unit to California Energy General Corp., a subsidiary of California Energy Co., Inc. The sale price was not disclosed. The Glass Mountain/Medicine Lake properties, including three wells capable of production, are located on Federal land in Siskiyou County, about 35 miles northeast of Mount Shasta and approximately 25 miles south of the California/Oregon border.

Source: Geothermal Resources Council Bulletin 4/93 


\section{MAGMA POWER COMPANY REPORTS 71 PERCENT GAIN IN EARNINGS FOR THIRD QUARTER OF 1993}

Magma Power Co. today announced that earnings for the third quarter ended September 30, 1993, increased 71 percent over the third quarter of 1992, as revenues grew 78 percent over the same period last year. For the third quarter, earnings were $\$ 20,453,000$, or $\$ .85$ per share, on revenues of $\$ 56,143,000$, compared with $\$ 11,966,000$, or $\$ .52$ per share, on revenues of $\$ 31,580,000$ in the third quarter of 1992.

Net income for the first nine months of 1993 was $\$ 39,469,000$, or $\$ 1.64$ per share, compared with the 1992 nine-month income of $\$ 24,216,000$, or $\$ 1.06$ per share. Revenues were $\$ 123,609,000$ and $\$ 77,299,000$ for the first nine months of 1993 and 1992, respectively.

Contributing to the record results was the inclusion during the second and third quarters of revenues and earnings from the three geothermal power plants Magma acquired at the end of March from Unocal Corp., as well as the strong operating performance of the company's four other geothermal plants in the Imperial Valley of California. For the third quarter of 1993, Magma generated 517,000 MW hours of electricity, up five percent from the second quarter of 1993, and ran at 115 percent of contract capacity compared with 104 percent of capacity during the second quarter.
"Our third quarter is typically our strongest because of seasonal pricing and our ability to schedule high operating rates," stated Paul M. Pankratz, Magma chairman and chief executive officer. "This year our third quarter results also benefitted from the inclusion of the acquired Unocal Salton Sea Power Plants. We are running our plants at exceptional operating rates, and are continuing to achieve cost savings as we successfully integrate the operations of our existing plants with the acquired Salton Sea plants." Commenting on the remainder of the year, Pankratz stated that Magma anticipates a record year with strong results as the company continues to operate its plants efficiently and as benefits continue to accrue from the acquired Salton Sea plants.

Source: Magma Power Co. Press Release $10 / 20 / 93$

\section{CALPINE ACQUIRES FREEPORT- MCMORAN INTEREST IN PRODUCING GEOTHERMAL PROPERTIES; ALSO GEOTHERMAL RIGHTS TO BIPHASE TURBINE}

On April 21, 1993, Calpine Corp. (San Jose, California), an independent power producer, announced it had purchased from Freeport-McMoRan Resource Partners, L.P. its remaining interest in producing geothermal properties for $\$ 63.5$ million. The properties are located in The Geysers area of northern California, the world's largest producing geothermal reservoir. 
Peter Cartwright, Calpine president, stated, "This transaction significantly strengthens Calpine's position as one of the industry's fastest growing independent power producers and affirms our commitment to the geothermal industry and to The Geysers. By carefully managing this valuable resource, we will preserve a long-term supply of reliable, economic, and environmentally sound power generation." This comprehensive approach to resource management is complemented by the company's efforts in leading an industrywide task force to advise the California Energy Commission on ways to extend the life of The Geysers.

The company first purchased an interest in FRP's producing properties in July 1990 for $\$ 27$ million and secured $\$ 200$ million in non-resource debt for the project's partnership. The properties, which Calpine will continue to operate through its subsidiary, Calpine Operating Plant Services, include the 20 MWe Bear Canyon and $27 \mathrm{MWe}$ West Ford power plants. Energy produced at these two power plants is sold to Pacific Gas and Electric Company under Standard Offer 4 contracts. Also included are three steam leases with a capacity of $320 \mathrm{MWe}$. Steam from these fields is sold to PG\&E and to the Sacramento Municipal Utility District. In addition to these properties, Calpine owns an interest in and operates the $20 \mathrm{MWe}$ Aidlin Geothermal Power Plant, also located in The Geysers.

Earlier, in September 1992, Calpine entered into a Project Development Agreement for the use of the .... biphase turbine to improve performance of geothermal power plants. The agreement gives Calpine the exclusive rights to use or install the turbine -- which may add up to 30 percent more power to an existing plant using existing well flow -- in the Western Hemisphere. In a typical project, Biphase will perform the engineering and supply the turbine, while Calpine will provide the construction management and plant operation. The companies will offer thirdparty projects as well as turnkey installations.

Source: Geothermal Resources Council Bulletin 4/93; IGA News 10-11/92

\section{PUNA GEOTHERMAL POWER GIVEN GO-AHEAD BY STATE; STATE COMMISSION RECOMMENDED GEOTHERMAL DEVELOPMENT}

The Puna Geothermal Venture 25-MWe hybrid binary plant began commercial operation in April 1993. The $\$ 120$ million project is located near the town of Pahoa on the Big Island of Hawaii. Puna Geothermal will deliver about $5 \mathrm{MWe}$ of power initially to Hawaii Electric Light Co., although HELCO has a contract to purchase the full output of the plant, enough to serve about 25,000 Big Island residents.

On December 21, 1992, the Hawaiian Energy Advisory Commission endorsed the use of geothermal energy in the state, provided that rigid standards are observed to ensure safety and health.

Source: Geothermal Resources Council Bulletin $3 / 93 ; 4 / 93$ 


\section{TRANS-PACIFIC WINS CONTRACT FOR GEOTHERMAL POWER PLANT IN NICARAGUA}

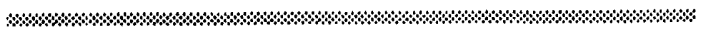

Dr. Tsvi Meidav, president of TransPacific Geothermal Co., met with the president of Nicaragua in March 1993 after reaching agreement on a contract for a 25 MWe geothermal plant (with options for a second 25 MWe plant) to be installed in the El Hoyo region of Nicaragua. The company feels this represents a major achievement in Central America since its proposal won over a competing Italian bid that offered $\$ 20$ million in tied-aid.

\section{THIRD GEOTHERMAL PLANT DEDICATED AT STEAMBOAT HOT SPRINGS}

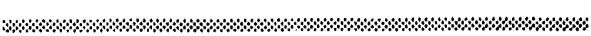

In June 1993 the Steamboat Development Corp. (a subsidiary of Far West Capitol) dedicated its newly constructed $32 \mathrm{MWe}$ (gross) binary power plant at Steamboat Hot Springs, about 10 miles south of Reno, Nevada. This is the third power plant to be constructed in this geothermal area. The Far West Capital 7 MWe (gross) binary plant came online in 1989, and the Caithness Corp. $12 \mathrm{MWe}$ (gross) flash plant went into service in 1988.

With the addition of the third plant, the capacity of the field is $51 \mathrm{MWe}$, and a second $32 \mathrm{MWe}$ plant is being considered.

Source: Geothermal Resources Council Bulletin 6-7/93 


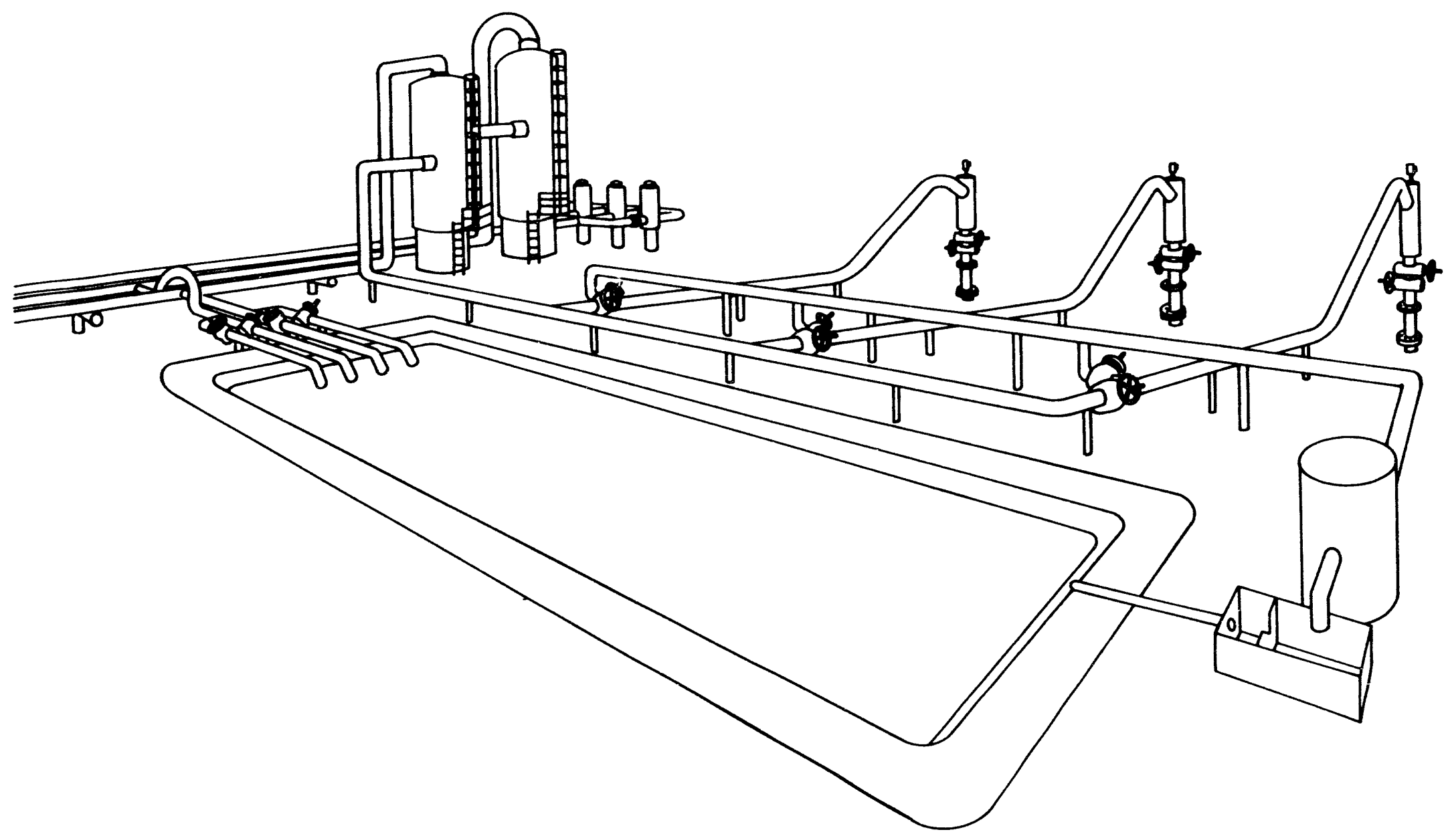

Geothermal Wells at Newberry Pilot Plant

A typical well pad, shown above, may include three production wells, high-and low-pressure steam separators, brine injection pumps, a pressure relief station, and a start-up silencer. (See Page 25) 


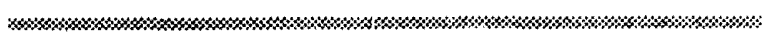

GEOTHERMAL ENERGY TAX CREDITS NOT WORKING AS INTENDED, INDUSTRY TELLS CONGRESS

Thomas C. Hinrichs, president of the Geothermal Resources Association, told a House Ways and Means Subcommittee that the 10 percent tax credit for investment in solar and geothermal development -- recently made permanent by Congress -- isn't sparking investment because the credit is presently not allowed to be used against the Alternative Minimum Tax, or AMT. Because of relatively higher initial costs, the AMT "is almost always triggered in the case of companies involved in geothermal development, and, therefore, the geothermal tax credit is not available to do the job Congress intended it to do," Hinrichs told the panel. "We strongly urge the Subcommittee and the Congress to support the full utilization of the energy tax credits against the AMT," he said.

Hinrichs, a vice president of Magma Power Co. of San Diego, praised the tax credit as "the single most effective federal program to promote renewable energy, stimulate investments, and enable the technology to develop and improve. "If the inability to apply the tax credit against the AMT were corrected by legislation, it would result in lower renewable energy prices being put forward in the bidding process" and "will enable renewable projects to compete with conventional fossil fuels in the bidding for new utility projects," Hinrichs testified. "Such successful bidding will result in the twin national benefits of energy independence and environmental enhancement," he added.

Hinrichs noted that "ironically, twice in the last three years the oil and gas industries have received relief from the AMT in tax legislation. Coupled with other tax breaks enjoyed by the oil and gas industries, renewables remain some distance from reaching the proverbial 'level playing field'."

Hinrichs said the legislation introduced by U.S. Rep. Jim McDermott (DWashington) (H.R. 2026) to allow the tax credits to apply against up to 25 percent of the AMT "is a fine start." He stressed, however, that "full utilization is the catalyst needed to spur renewable development."

The Geothermal Resources Association is composed of 15 geothermal energy companies that operate geothermal power plants producing a total of approximately 2,800 megawatts of clean power. A 100megawatt power plant can support the energy needs of a community of 100,000 , he noted.

Source: Geothermal Resources Association

\section{FINANCING SET FOR TWO NEW GEOTHERMAL PROJECTS}

Under a purchase-lease back agreement, General Electric Capital Corp. (a unit of General Electric) financed the construction of two new geothermal power plants by OESI Power Corp. of Portland, Oregon. A $\$ 37.5$ million Ioan was 
approved to develop $12.5 \mathrm{MWe}$ at the Rye Patch geothermal field in Pershing Co., Nevada, and the second project, a $32 \mathrm{MWe}$ plant at the Heber field in Imperial Co., California, received a loan of $\$ 115$ million.

Sierra Pacific Power Co. has contracted for the output of the Rye Patch project, and electricity from the Heber plant will be sold to Southern California Edison under the last remaining Standard Offer 4 contract for geothermal development. The latter contract provides approximately $\$ 100 / \mathrm{MWh}$ for electricity and bonuses for availability.

OESI drilled 11 production wells at Heber, nine at 4,000 feet and two at
6,000 feet. Multiple injection wells drilled from one platform will be used. They are part of the field operations of the earlier 45 MWe experimental binary plant in the area.

General Electric Capital owns the geothermal leases at Heber and owns and operates the 50 MWe flash plant in the eastern part of the field. Electricity produced by both Heber plants is transmitted 45 miles to SCE facilities via a $120 \mathrm{kv}$ power line built by the geothermal operators in the Imperial Valley.

When the Rye Patch and the new Heber plant were completed in 1993, they were purchased by General Electric Capital and leased back to OESI. 
TWO BPA GEOTHERMAL POWER PROJECTS GET GO-AHEAD

\%\$\%

As part of its Resource Supply Expansion Program, the Bonneville Power Administration has signed memoranda of understanding with two geothermal developer/municipal utility teams to develop two demonstration geothermal projects. The Program addresses the objective of the Northwest Power Planning Council's plan to expand the supply of cost-effective, reliable resources for the region.

The first of the pilot projects approved is a $\$ 100$ million, 30 average $\mathrm{MWe}$ generating station at Newberry Crater, 35 miles southeast of Bend in Deschutes National Forest in central Oregon. CE Exploration, a subsidiary of California Energy Co., and the Eugene Water \& Electric Board (EWEB), Oregon's largest publicly owned electric utility, will develop the resource and construct the plant. EWEB and BPA will jointly purchase plant output that will be sufficient to supply power to 30,000 homes.

The second project approved will be undertaken by Trans-Pacific Geothermal Corp. and the Springfield Utility Board (SUB). The $30 \mathrm{MWe}, \$ 70$ million pilot project will be located just outside of Vale, in Malheur County, about 15 miles west of the Idaho border. SUB will purchase about $9 \mathrm{MWe}$ of the output, and BPA will buy the rest; SUB will get a billing credit from BPA for its purchase.
Both projects will be located on federally owned land. The U.S. Forest Service administers the site of the Newberry plant, and the Bureau of Land Management, the Vale site. In both cases, the Federal managers will be the lead agency in conducting environmental reviews of the projects. The Forest Service environmental impact statement (EIS) is expected to take a minimum of 18 months and cost more than $\$ 600,000$-- paid partly by CE Exploration. The BLM studies of the Vale site will require from $1-1 / 2$ to 2 years. BPA will subsequently make decisions on final contracts before construction begins.

Six to 10 wells will be drilled to supply fluid to the Newberry plant, and the condensate will be injected into the subsurface. An 8.5-mile transmission line will connect the project with the BPA grid. As of this writing, the Trans-Pacific field development plans have not been announced.

According to the Eugene Register Guard, the EWEB has been the most interested of Oregon's utilities in geothermal possibilities for years. "Part of its interest stems from the fact that EWEB generates 20 percent of its own power," the paper noted, "whereas most of the 'publics' buy all of their electricity from BPA."

A copy of the Scoping Report for the Newberry Geothermal Pilot Project, which includes sections on the EIS process and various environmental issues, may be obtained from: Woodward - Clyde Consultants, 111 SW Columbia, Suite 900 , Portland, OR 97201. 
Source: Geothermal Resources Council Bulletins 2/93; 5/93; BPA This Week 12/28/92 and 1/4/93; Eugene Register Guard 9/8/91; Newberry Geothermal Pilot Project (CE publication.)

\section{THE GEYSERS GEOTHERMAL FIELD HAS REACHED MATURITY}

(Excerpted from an editorial written by Ted Wilmsen, President of The Geysers Geothermal Assn., published in the Steamline, the association's newsletter.)

When we say The Geysers is now a mature field, some people only hear the negative -- that The Geysers is getting old. 1 guess thirty-something might be considered old by some. We often use the words mature or experienced as a replacement for old, since old seems to have such a negative connotation these days. I see the word mature as a more self-descriptive word, since experienced or old are words which are always relative to something else.

Without question The Geysers reservoir has lost its high pressure "kick." Over the past couple of years...the developers and generators have been...trying to understand the changes and take appropriate action so as to best utilize the remaining resource. In some cases new contracts have been negotiated which address the present condition and provide incentives to facilitate the opportunities of the future. The name of the game now is how to best utilize the remaining steam and its potential to generate electricity.
Getting a handle on just how much future steam exists is an important component in developing the economics required to justify modifications. An unprecedented spirit of cooperation has been achieved in getting together all the parties and all the relevant data so as to produce the best possible forecast model of the remaining steam and its generation potential.

Armed with this information, all parties are now able to evaluate how best to utilize their remaining resource. It is also obvious to all parties that it is in their collective best interest to view the remaining steam as a depletable, valuable resource which must be efficiently utilized.

It is with the achievement of this new cooperative spirit between all the different parties that I now view The Geysers as not only having a resource that is mature, but a resource management philosophy that is mature. I therefore see The Geysers, now being mature, as positive for the future. This will ensure that The Geysers continues to be a valuable source of energy and jobs for many, many years.

\section{TREATED WASTEWATER TO BE INJECTED AT GEYSERS TO RESTORE PRODUCTION LEVELS}

Funding from a number of sources is being coordinated to support construction of a 26-mile pipeline to carry treated wastewater from the city of Clear Lake and other localities. The effluent is to be injected into the formation in an effort to restore the field's productivity, which has 
declined significantly after over 30 years of commercial use. Injection has been used successfully at The Geysers and other geothermal areas worldwide for several decades, proving to be an effective sustainable resource management practice.

And, two producers in the area -Northern California Power Agency and Calpine Inc. -- have had such success in increasing production with injection that they are willing to participate in a program to use the wastewater to reinvigorate the field. The Southeast Geysers Effluent Pipeline and Injection Project is also supported by Lake County's special districts. The main effluent pipeline will be owned and operated by Lake County, with effluent sold to NCPA and Calpine, who will own and operate the secondary distribution pipelines. PG\&E will purchase effluent-based steam from the additional supply created.

The total cost of the project is $\$ 38$ million, with $\$ 29$ million accounted for by the pipeline and related construction at the field and $\$ 9$ million dedicated to improvements to the two sewage treatment plants involved. The initial DOE contribution paid for the pre-design report, which is currently available, and the required environmental studies expected to be completed in January 1994.

A number of other funding commitments have been made or are pending. In addition to further contributions from DOE, funds are to be provided by the State of California, a California Energy Commission loan, Bureau of Land Management (royalty reduction grant), Economic Development
Administration (Dept. of Commerce), Environmental Protection Agency, the Agriculture Rural Development Fund, Lake County (through an indebtedness to the revolving loan fund or other source), and industry (NCPA, Calpine, PG\&E). Construction is expected to begin in the third quarter of 1994.

If the project is a success, it should result in a net gain of 20 to $50 \mathrm{MWe}$ in plant capacity, equating to as much as 280,000 MWh of electricity per year. In addition to the energy benefits, the project will also provide an environmentally superior method of wastewater disposal, help retain jobs in the region, and provide tax and lease revenues for local communities and state and Federal governments.

Source: Geothermal Resources Council Bulletins 3/93; 5/93; Lake County Planning Department

\section{EPRI AND WESTERN UTILITIES SEEK TO ADVANCE GEOTHERMAL POWER TECHNOLOGY}

Early in 1993 the Electric Power Research Institute (EPRI) issued a Request for Proposal (RFP) soliciting participation in Phase I (concept development, evaluation, and selection) of a planned multi-phase program to develop the next generation geothermal power plant, and a contract has been let. The program objective is to accelerate the commercial availability of higher-efficiency, lower-cost geothermal power generation technologies. Funding 
for Phase I will be provided by DOE, a consortium of western utilities, and EPRI.

Those interested in receiving information on this program should contact: H.K. "Pete" McCluer, Consultant, P.O. Box 650, Mt. Aukum, CA 95655, phone (209) 245-4171, fax (209) 2454623.

Source: Geothermal Resources Council Bulletin 2/93; personal communication

\section{NEW APPROACH FOR MARKETING KLAMATH FALLS DISTRICT HEATING SYSTEM COULD BENEFIT PROMOTERS OF OTHER SYSTEMS}

The Klamath Falls Geothermal District Heating System, completed in 1981, had to overcome many problems, both political and technical, before reaching its current state of reliability in 1991. However, until 1992, there was no formal marketing plan for the system, the lack of which combined with a history of poor availability to reduce or eliminate interest on the part of building owners to join. At the time, the system served only the original 14 governmental (state, Federal, and local) buildings connected at start-up in 1981. The revenue from these buildings did not cover its operating costs, and the city was faced with a difficult decision -- develop the revenue required to make the system selfsupporting or shut it down.

As a result, a marketing strategy was developed by the Geo-Heat Center designed to address the major issues involved:
- rates

- customer retrofit cost

- financing

- system reliability

- city creditability

- manpower requirements.

The solutions to each of these problems, explanations of how they were reached, and the results are described in a report issued by the Geo-Heat Center, titled "Marketing the Klamath Falls Geothermal District Heating System," in June 1993. Other cities promoting such systems could possibly benefit from the approach taken in Klamath Falls. Copies of the report may be obtained by contacting:

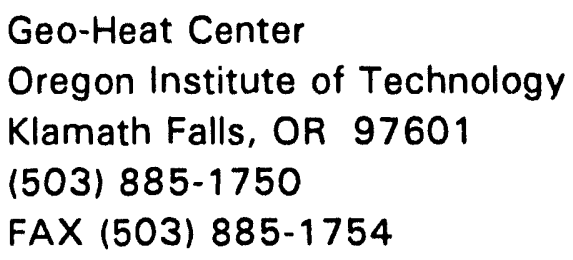

\section{GEO-HEAT CENTER BULLETIN PROVIDES GUIDE TO GEOTHERMAL SPAS FOR VISITORS, INVEST. MENT OPPORTUNITIES}

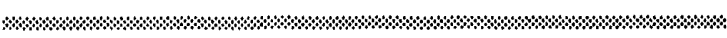

Dedicating the entire March 1993 issue of its Quarterly Bulletin to the history and current conditions of geothermal spas in this country, the Geo-Heat Center provided a directory of major U.S. facilities and a discussion of investment potential in this segment of the health and fitness industry, particularly in Hawaii. The Bulletin notes that in the U.S., the use of natural springs, especially geothermal springs, has gone through three stages of development: 
1) use by Indians as a sacred place;

2) development of plush hot springs resorts to emulate the elegant therapeutic spas of Europe; and

3) use as a place of relaxation and fitness.

By the 1940s, the interest in spas languished for numerous reasons -- e.g., lack of support of these institutions by government and health insurance providers -- and most of the majestic resorts went into decline and closed. In recent years, however, spa development has beer: renewed as part of the "back to nature" movement toward physical fitness rather than as the formalized medical treatment centers of Europe. Many of the medical claims have been discredited in the U.S., and the natural waters have required chlorination or other chemical treatment.

Today, there are over 115 major geothermal spas in the U.S. and many smaller ones, along with thousands of hot springs. The majority of these are located in the volcanic regions of the western states, but several famous ones still exist in the east. The Bulletin notes, for example, the state park at the old Saratoga, NY, spa and the National Park at Hot Springs, Arkansas, where a full range of tub and pool baths and showers are offered. At Warm Springs, Georgia, the Institute for Rehabilitation -- an outgrowth of the Warm Springs Foundation dedicated to treatment of polio victims, including President Franklin D. Roosevelt -- offers comprehensive services in medical and vocational rehabilitation and independent living to people with a broad range of disabilities.

A Bulletin article by representatives of the Hawaiian Natural Energy Institute reports that health spas and resorts, represeriting a major part of the health and fitness industry, have grown in popularity and offer high investment potential. Revenues from U.S. spas of all types are presently estimated at $\$ 10$ billion annually, and the number of spa-goers is projected to grow from 31 percent of the adult population in 1987 to 41 percent in 1995 . The article adds that Hawaii is underrepresented in this industry with only four out of 150 full-fledged bath spas nationwide, among the smallest in the industry averaging 14 beds per facility versus the national average of 96 . The authors, James L. Woodruff and Patrick K. Takahashi, then cite the available historical and scientific information on the location of hot mineral water sources in Hawaii that offers clues as to where spa development would be possible and discusses related current activities and future considerations. Their concept of a Hawaiian geo-spa is illustrated below, along with a typical California facility.

Copies of the Bulletin, which contains a listing of guides to various types of U.S. spas, is available from:
Geo-Heat Center
Oregon Institute of Technology
Klamath Falls, OR 97601
(503) 885-1750
FAX (503) 885-1754 


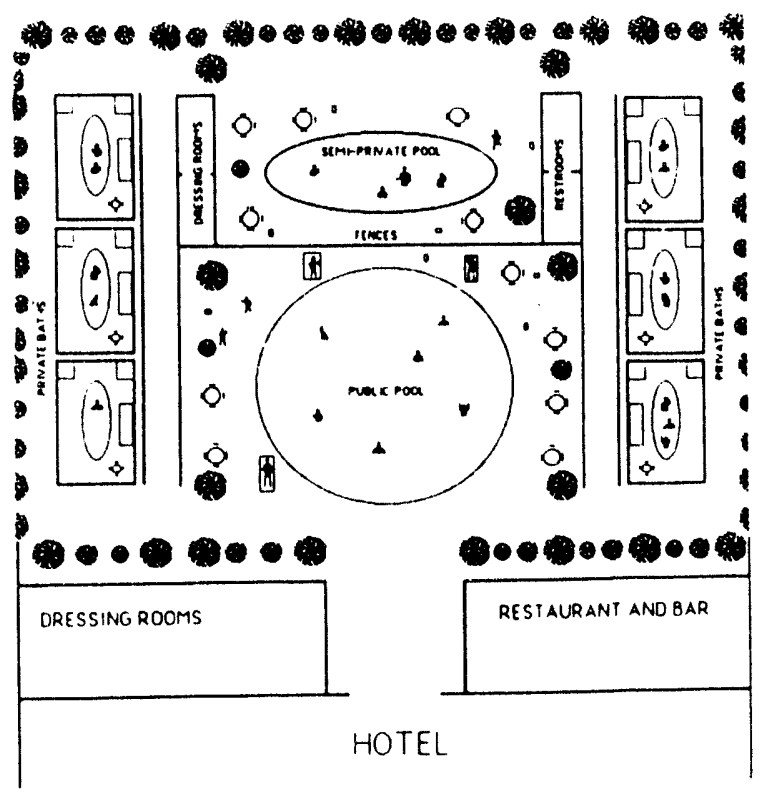

Design for a geothermal spa offering private, semi-private, and public bathing facilities.

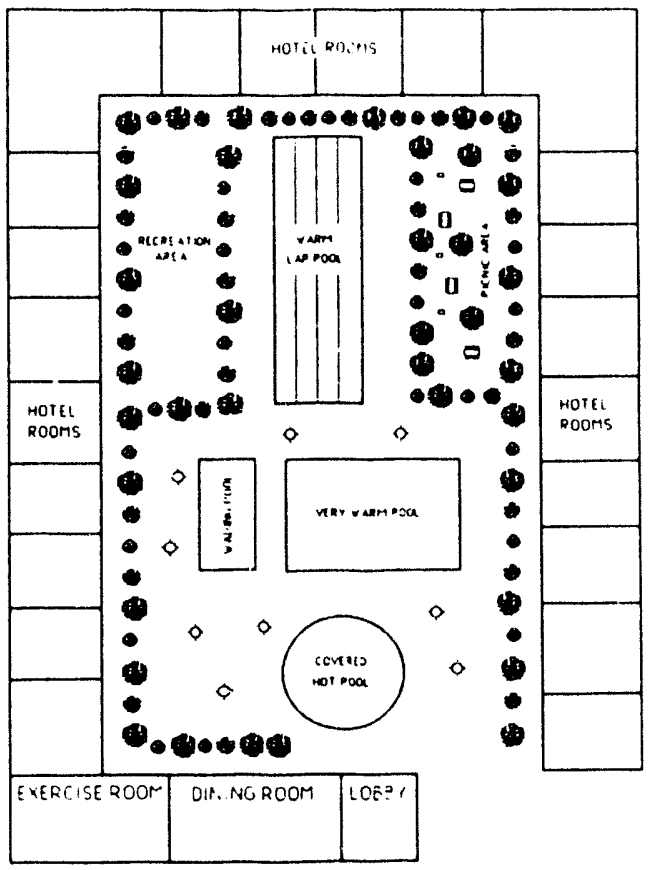

General scheme of a modern geothermal spa located in California. 


\section{LOW TEMPERATURE RESOURCES IN NEVADA}

The Nevada Bureau of Mines and Geology (NBMG) has been selected as the Nevada agency to participate in the DOEfunded Geothermal Low-Temperature Reservoir Assessment Program initiated in 1991. The objective of the program is to promote greater utilization of the nation's widely distributed low- and moderatetemperature geothermal energy and earthheat resour: as. (See GPM No. 14.)

NBMG will prepare an up-to-date inventory of the state's low- and moderatetemperature geothermal resources from $10^{\circ} \mathrm{C}\left(50^{\circ} \mathrm{F}\right)$ - above mean annual temperature to $150^{\circ} \mathrm{C}\left(300^{\circ} \mathrm{F}\right)$, including those not previously identified, and in cooperation with the Geo-Heat Center, analyze which of these resources are near population centers and thus more likely for development. This inventory will make use of considerable geothermal resource data collected at NBMG in the late 1970s and of new data from published and unpublished sources. Water chemistry data are available for many thermal springs and wells, and will be made a part of the database for the project. A few new analyses of thermal waters are planned as well. The project will utilize the extensive GIS (Geographic Information Systems) capabilities available at NBMG to tabulate exact locations (map coordinates -- for example, longitude and latitude) of all known thermal springs and wells.

Source: Geo-Heat Center Quarterly Report $1-3 / 93$

\section{POWER PLANT DATA INDICATE CONTINUED GEOTHERMAL GROWTH}

The U.S. geothermal industry has announced plans to add $702 \mathrm{MWe}$ of additional geothermal electric capacity through the year 2000 . The plans include 22 new plants and the expansion of three existing plants. Eight of the new plants are planned for seven previously undeveloped geothermal sites. Two plants planned for Oregon and one for Alaska will be the first geothermal developments in their respective states. The table below outlines the planned capacity additions and target start-up dates.

Most of the projects listed in the table have power sales agreements. For those without power sales agreements, other factors, such as sponsorship by a utility or BPA, warranted their inclusion. Problems confirming the resource at Rye Patch have raised questions concerning the feasibility of Rye Patch A and B. The two associated $14 \mathrm{MWe}$ power sales agreements with Sierra Pacific may ultimately be used at some other location. 


\begin{tabular}{|c|c|c|c|c|}
\hline Plant Name & Location & Developer & MW & Date \\
\hline Caithness Binary & $\begin{array}{l}\text { Steamboat Springs. } \\
\text { NV }\end{array}$ & Caithness & 8 & 1994 \\
\hline Coithness 1 & Dixie Valley, NV & Caithness & 19 & 1995 \\
\hline Caithness $2 \cdot 7$ & $\begin{array}{l}\text { Dixie Valley } \\
\text { Steamboat Springs. } \\
\text { NV }\end{array}$ & Caithness & 130 & 1995 \\
\hline $\begin{array}{l}\text { Newberry } 1 \text { BPA } \\
\text { Demo }\end{array}$ & Bend, OR & $\begin{array}{l}\text { Eugene Water \& } \\
\text { Electric Board \& } \\
\text { California Energy } \\
\end{array}$ & 30 & 1996 \\
\hline Fallon Navy Plants & Fallon, NV & TBD & 160 & 1996 \\
\hline Fishlake 1 & $\begin{array}{l}\text { Esmeralda County, } \\
\text { NV }\end{array}$ & Magma Power & 14 & 1995 \\
\hline LADWP Coso & China Lake, CA & LADWP \& Calpine & $\begin{array}{l}60 \\
90 \\
\end{array}$ & $\begin{array}{l}1996 \\
2000 \\
\end{array}$ \\
\hline Lake City Unit 1 & Lake City. CA & $\begin{array}{l}\text { Transpacific \& } \\
\text { Constellation } \\
\end{array}$ & 10 & 1994 \\
\hline Del Ranch Expansion & Salton Sea, CA & Magma & 6 & 1994 \\
\hline JJ Elmore Expansion & Salton Sea, CA & Magma & 6 & 1994 \\
\hline JM Leathers & Salton Sea, CA & Magma & 6 & 1994 \\
\hline OESI Unalaska & Unalaska Island, AK & $\begin{array}{l}\text { Alaska Energy } \\
\text { Authority, OESI }\end{array}$ & 12 & 1996 \\
\hline Rye Patch A & Carson, NV & OESI & 14 & TBO \\
\hline Rye Patch B & Carson, NV & OESI & 14 & TBD \\
\hline San Emidio 1 & San Emidio, NV & San Emidio Resources & 5 & TBD \\
\hline San Emidio II & San Emidio, NV & San Emidio Resources & 22 & TBD \\
\hline Kalina Steamboat 5 & $\begin{array}{l}\text { Steamboat Springs, } \\
\text { NV } \\
\end{array}$ & Far West Capital & 36 & 1996 \\
\hline $\begin{array}{l}\text { Glass Mountain } \\
\text { BPA Demo }\end{array}$ & Glass Mountain, CA & California Energy & 30 & TBD \\
\hline Vale BPA Demo & Vale, OR & $\begin{array}{l}\text { Transpacific } \\
\text { Geothermal }\end{array}$ & 30 & TBD \\
\hline
\end{tabular}

The key to the abbreviations used in the power plant tables is as follows

Plant Type Utilities

\begin{tabular}{|c|c|c|c|c|c|}
\hline DS & - & Dry Steam & BPA & $\cdot$ & Bonneville Power Administration \\
\hline DF & - & Dual Flash & CCPA & - & Central California Power Agency \\
\hline SF & - & Single Fiash & HELCO & - & Hawaii Electric Light Co. \\
\hline \multirow[t]{11}{*}{$\mathbf{B}$} & - & Binary & HD & - & Imperial Irrigation District \\
\hline & & & LADWP & - & Los Angeles Dept. of Water and Power \\
\hline & & & NCPA & - & Northern California Power Agency \\
\hline & & & PG\&E & - & Pacific Gas and Electric Co. \\
\hline & & & PP\&L & $\cdot$ & Pacific Power and Light Co. \\
\hline & & & PSPQL & - & Puget Sound Power and Light Co. \\
\hline & & & SCE & $\cdot$ & Southern California Edison \\
\hline & & & SDG\&E & $\cdot$ & San Diego Gas and Electric Co. \\
\hline & & & SPP & - & Sierra Pacific Power Co. \\
\hline & & & SMUD & - & Sacramento Municipal Utility District \\
\hline & & & UPD & - & Utah Power Division of Pacific Corp. \\
\hline
\end{tabular}




\begin{tabular}{|c|c|c|c|c|c|}
\hline \multicolumn{6}{|c|}{$\begin{array}{l}\text { GEOTHERMAL ELECTRIC POWER PLANTS OPERATIONAL, UNDER CONSTRUCTION, AND PLANNED } \\
\text { IN THE UNITED STATES } \\
\text { (Dry Steam Plants at The Geysers) }\end{array}$} \\
\hline $\begin{array}{l}\text { PLANT } \\
\text { NAME }\end{array}$ & $\begin{array}{c}\text { FIELD } \\
\text { DEVELOPER } \\
\end{array}$ & PLANT OWNER & UTLITY & (MW) & $\begin{array}{l}\text { YEAR } \\
\text { ON LINE } \\
\end{array}$ \\
\hline PG\&E Unit No. $1^{2}$ & UNOCAL/Magma/Thermal & PG\&E & PG\&E & 11 & 1960 \\
\hline No. $2^{\mathrm{a}}$ & $\cdot$ & $"$ & " & 13 & 1963 \\
\hline No. $3^{\text {an }}$ & $\cdot$ & • & • & 27 & 1967 \\
\hline No. $4^{2}$ & $\cdot$ & " & $\cdot$ & 27 & 1968 \\
\hline No. 5 & • & •" & $\cdot$ & 53 & 1971 \\
\hline No. 6 & " & $"$ & $\cdot$ & 53 & 1971 \\
\hline No. 7 & $\cdot$ & • & $\cdot$ & 53 & 1972 \\
\hline No. 8 & $\cdot$ & $\cdot$ & $\cdot$ & 53 & 1972 \\
\hline No. 9 & •" & $\cdot$ & • & 53 & 1973 \\
\hline No. 10 & • & $\cdot$ & $\cdot$ & 53 & 1973 \\
\hline No. 11 & • & $\bullet$ & $\cdot$ & 106 & 1975 \\
\hline No. 12 & . & $\cdot$ & $\cdot$ & 106 & 1979 \\
\hline No. $15^{\circ}$ & $\begin{array}{l}\text { Geothermal Resources } \\
\text { International }\end{array}$ & • & • & 59 & 1979 \\
\hline No. 13 & $\begin{array}{l}\text { Santa Rosa Geothermal } \\
\text { Co. }^{b}\end{array}$ & $"$ & $\cdot$ & 133 & 1980 \\
\hline No. 14 & $\begin{array}{l}\text { UNOCAL/Magma/Thermal } \\
\text { (Natomas) }\end{array}$ & $"$ & $\cdot$ & 109 & 1980 \\
\hline
\end{tabular}

Retired

Formed by Calpine Corp. and Freeport-McMoran as new owner of leases and steam supply operations; originally Aminoil properties 


\begin{tabular}{|c|c|c|c|c|c|}
\hline \multicolumn{6}{|c|}{$\begin{array}{l}\text { GEOTHERMAL ELECTRIC POWER PLANTS OPERATIONAL, UNDER CONSTRUCTION, AND PLANNED } \\
\text { IN THE UNITED STATES } \\
\text { (Dry Steam Plants at The Geysers) }\end{array}$} \\
\hline $\begin{array}{l}\text { PLANT } \\
\text { NAME }\end{array}$ & $\begin{array}{c}\text { FIELD } \\
\text { DEVELOPER }\end{array}$ & PLANT OWNER & UTHITY & $\begin{array}{l}\text { RATED } \\
\text { CAPACITY } \\
\text { (MW) }\end{array}$ & $\begin{array}{l}\text { YEAR } \\
\text { ON LINE }\end{array}$ \\
\hline No. 17 & $\begin{array}{l}\text { UNOCAL/Magma/Thermal } \\
\text { (Natomas) }\end{array}$ & PG\&E & PG\&E & 110 & 1982 \\
\hline No. 18 & $\begin{array}{l}\text { UNOCAL/Magma/Thermal } \\
\text { (Natomas) }\end{array}$ & PG\&E & PG\&E & 110 & 1983 \\
\hline SMUDGEO No. 1 & Santa Rosa Geothermal Co. ${ }^{b}$ & $\begin{array}{l}\text { Sacramento } \\
\text { Municipal Utility } \\
\text { District }\end{array}$ & SMUD & 72 & 1983 \\
\hline NCPA No. $1^{c}$ & $\begin{array}{l}\text { Northern Calif. Power } \\
\text { Agency (originally Grace } \\
\text { Geothermal) }\end{array}$ & NCPA & NCPA & 110 & 1983 \\
\hline $\begin{array}{l}\text { Sants Fe } \\
\text { Geothermal } 1\end{array}$ & $\begin{array}{l}\text { Santa Fe Geothermal } \\
\text { (originally Occidental) }\end{array}$ & Santu Fe Geothermal & PG\&E & 80 & 1984 \\
\hline Bottle Rock ${ }^{d}$ & NCPA & $\begin{array}{l}\text { Calif. Dept of Water } \\
\text { Resources }\end{array}$ & $\begin{array}{l}\text { Calif. Dept of Water } \\
\text { Resources }\end{array}$ & 55 & 1984 \\
\hline NCPA No. $2^{\mathrm{c}}$ & NCPA & NCPA & NCPA & 110 & 1985 \\
\hline PG\&E Unit No. 16 & Santa Rosa Geothermal Co. ${ }^{b}$ & PG\&E & PG\&E & 110 & 1985 \\
\hline No. 20 & $\begin{array}{l}\text { UNOCAL/Thermal } \\
\text { (Diamond Shamrock) }\end{array}$ & PG\&E & PG\&E & 110 & 1985 \\
\hline Cold Water Creek & $\begin{array}{l}\text { Cold Water Creek Operating } \\
\text { Co. }\end{array}$ & $\mathrm{CCPA}^{\mathrm{e}}$ & $\mathrm{CCPA}^{\mathrm{f}}$ & 124 & 1988 \\
\hline
\end{tabular}

c Originally NCPA Nos. 2 and 3

d Closed

e Plant ownership divided among Sacramento Municipal Utility District (SMUD), Modesto Irrigation District (MID), and the City of Santa Clara

f The new partnership of Calpine Corp. and Freeport-McMoRan owns both field and power plant operations; originally Geysers Geothermal properties 


\begin{tabular}{|c|c|c|c|c|c|}
\hline \multicolumn{6}{|c|}{$\begin{array}{l}\text { GEOTHERMAL ELECTRIC POWER PLANTS OPERATIONAL, UNDER CONSTRUCTION, AND PLANNED } \\
\text { IN THE UNITED STATES } \\
\text { (Dry Steam Plants at The Geysers) }\end{array}$} \\
\hline $\begin{array}{l}\text { PLANT } \\
\text { NAME }\end{array}$ & $\begin{array}{c}\text { FIELD } \\
\text { DEVELOPER }\end{array}$ & PLANT OWNER & UTHLTY & $\begin{array}{l}\text { CAPACITY } \\
\text { (MW) }\end{array}$ & $\begin{array}{c}\text { YEAR } \\
\text { ON LINE }\end{array}$ \\
\hline Bear Canyon Craek & $\begin{array}{l}\text { Santa Rosa Geothermal } \\
\text { Co. } f\end{array}$ & Santa Rosa ${ }^{f}$ & PG\&E & 22 & 1988 \\
\hline $\begin{array}{l}\text { Joseph W. Aldlin } \\
\text { Power Plant }\end{array}$ & $\begin{array}{l}\text { Geothermal Energy } \\
\text { Partners } 8\end{array}$ & $\begin{array}{l}\text { Geothermal Energy } \\
\text { Partners/Cloverdale } \\
\text { Geothermal } \\
\text { Partners }^{h}\end{array}$ & PG\&E & 20 & 1989 \\
\hline
\end{tabular}

g A subsidiary of Mission Power is general partner

h Calpine Corp. and Metlife Capital Corp. (affiliate of Metropolitan Life Ins. Co.) 


\begin{tabular}{|c|c|c|c|c|c|c|c|}
\hline \multicolumn{8}{|c|}{$\begin{array}{l}\text { GEOTHERMAL ELECTRIC POWER PLANTS OPERATIONAL, UNDER CONSTRUCTION, AND PLANNED } \\
\text { IN THE UNTTED STATES } \\
\text { (Hot Water Plants) } \\
\end{array}$} \\
\hline $\begin{array}{l}\text { LOCATION } \\
\text { (State and Site) } \\
\end{array}$ & $\begin{array}{l}\text { PLANT } \\
\text { NAME } \\
\end{array}$ & TYPE & $\begin{array}{l}\text { FIELD } \\
\text { DEVELOPER }\end{array}$ & $\begin{array}{l}\text { PLANT } \\
\text { OWNER }\end{array}$ & UTILTYY & $\begin{array}{l}\text { RATED } \\
\text { CAPACITY } \\
\text { (MW) }\end{array}$ & $\begin{array}{c}\text { YEAR } \\
\text { ON LINE } \\
\end{array}$ \\
\hline \multicolumn{8}{|l|}{ ALASKA } \\
\hline & Unalaska & TBD & OESI & $\begin{array}{l}\text { Alaska Energy } \\
\text { Authority }\end{array}$ & TBD & 12 & 1995 \\
\hline \multicolumn{8}{|l|}{ CALIFORNIA } \\
\hline \multirow[t]{6}{*}{ Coso Hot Springs } & $\begin{array}{l}\text { Navy Plant } \\
\text { No. } 1, \text { Units } \\
\text { No. } 1,2, \& 3\end{array}$ & DF & Califomia Energy" & $\begin{array}{l}\text { Califormin } \\
\text { Energy" }\end{array}$ & SCE & 80 & 1987-1988 \\
\hline & $\begin{array}{l}\text { BLM East } \\
\text { (Units 1\&2) }\end{array}$ & DF & Califomia Energy & $\begin{array}{l}\text { Califomia } \\
\text { Energy" }\end{array}$ & SCE & 48 & 1988 \\
\hline & BLM West & DF & Califormiz Energy" & $\begin{array}{l}\text { Califormia } \\
\text { Energy }\end{array}$ & SCE & 28 & 1989 \\
\hline & $\begin{array}{l}\text { Navy Plant } \\
\text { No. } 2 \text {, Units } \\
\text { No. } 4,5, \& 6\end{array}$ & DF & Califormia Energy & $\begin{array}{l}\text { Californin } \\
\text { Energy }\end{array}$ & SCE & 80 & 1989 \\
\hline & LADWP I & DF & $\begin{array}{l}\text { Los Angeles Dept. } \\
\text { of Water and Power } \\
\text { (LADWP) }\end{array}$ & LADWP & LADWP & 60 & 1996 \\
\hline & LADWP II & DF & $\begin{array}{l}\text { Los Angeles Dept. } \\
\text { of Water and Power } \\
\text { (LADWP) }\end{array}$ & LADWP & LADWP & 90 & 2000 \\
\hline \multirow[t]{2}{*}{ East Mesa } & $\begin{array}{l}\text { GEM } 1 \text { (formerly } \\
\text { B.C. McCabe) }\end{array}$ & B & $\begin{array}{l}\text { GEO } \\
\text { Operator/Mission }{ }^{b, c}\end{array}$ & GEO/Mission $^{c}$ & SCE & $12.5^{\mathrm{d}}$ & 1980 \\
\hline & Ormesa I & B & OESI & OESI & SCE & 24 & 1986 \\
\hline
\end{tabular}

a Various venture partners are involved in all California Energy Coso plants

Magma Power original owner

Mission Energy, a subsidiary of SCE

Enlarged from $10 \mathrm{MWe}$ 


\begin{tabular}{|c|c|c|c|c|c|c|c|}
\hline \multicolumn{8}{|c|}{$\begin{array}{l}\text { GEOTHERMAL ELECTRIC POWER PLANTS OPERATIONAL, UNDER CONSTRUCTION, AND PLANNED } \\
\text { IN THE UNITED STATES } \\
\text { (Hot W\&ter Plants) }\end{array}$} \\
\hline $\begin{array}{l}\text { LOCATION } \\
\text { (State and Site) }\end{array}$ & $\begin{array}{l}\text { PLANT } \\
\text { NAME } \\
\end{array}$ & TYPE & $\begin{array}{l}\text { FIELD } \\
\text { DEVELOPER }\end{array}$ & $\begin{array}{l}\text { PLANT } \\
\text { OWNER }\end{array}$ & UTLITY & $\begin{array}{l}\text { RATED } \\
\text { CAPACITY } \\
\text { (MW) }\end{array}$ & $\begin{array}{c}\text { YEAR } \\
\text { ON LINE } \\
\end{array}$ \\
\hline \multicolumn{8}{|c|}{ CALIFORNIA (Cont'd) } \\
\hline & Ormess II & B & $\begin{array}{l}\text { OESI/Harbert } \\
\text { Intermational }\end{array}$ & OESI/Harbert & SCE & 17 & 1988 \\
\hline & Ormesa IE & B & OESI & OESI & SCE & 8 & 1988 \\
\hline & Ormesa IH & B & OESI & OESI/Harbert & SCE & 6 & 1989 \\
\hline & GEM 2 & DF & GEO/Mission $^{c}$ & GEO/Mission $^{c}$ & SCE & 37 & 1989 \\
\hline Glass Mountain & Glass Mountain I & DF & Califormia Energy & Californis Energy & $\mathrm{BPA}^{\mathrm{C}}$ & 30 & 1996 \\
\hline \multirow[t]{3}{*}{ Heber } & $\begin{array}{l}\text { Heber Dual } \\
\text { Flash Power } \\
\text { Plant }\end{array}$ & DF & $\begin{array}{l}\text { Chevron } \\
\text { Resources Co. }\end{array}$ & $\begin{array}{l}\text { Calpine } \\
\text { Corp./ERC } \\
\text { International }\end{array}$ & SCE & 47 & 1985 \\
\hline & $\begin{array}{l}\text { Heber Binary } \\
\text { ProjoctB }\end{array}$ & B & Chevron & To be sold by SDG\&E & SDG\&E & 45 & 1985 \\
\hline & Second Imperial & B & $\begin{array}{l}\text { Second Imperial } \\
\text { Geothermal Co. }\end{array}$ & GE Capital & SCE & 37 & 1993 \\
\hline \multirow[t]{4}{*}{ Mono-Long Valley } & $\begin{array}{l}\text { Mammoth } \\
\text { Pacific (MP) } \\
\text { Unit } 1\end{array}$ & B & Pacific Energy ${ }^{h}$ & Pacific Energy ${ }^{h}$ & SCE & 7 & 1984 \\
\hline & MP Unit II & B & Pacific Energy ${ }^{h}$ & $\begin{array}{l}\text { Pacific } \\
\text { Energy }\end{array}$ & SCE & 10 & 1990 \\
\hline & MP Unit III & B & Pacific Energy ${ }^{h}$ & Pacific Energy ${ }^{h}$ & SCE & 10 & $\begin{array}{l}1994 \\
\text { (est.) }\end{array}$ \\
\hline & $\begin{array}{l}\text { Pacific Lighting } \\
\text { Energy Systems } \\
\text { (PLES) Unit I }\end{array}$ & B & Pacific Energy ${ }^{h}$ & $\begin{array}{l}\text { Pacific } \\
\text { Energy/Constellation }\end{array}$ & SCE & 10 & 1990 \\
\hline
\end{tabular}

e Bonneville Power Administration Geothermal Power Project

Partnership of Dravo Corp. and Centennial Energy original owner

B Demonstration plant supported by the U.S. Department of Energy; currently not in operation

h Subsidiary of Pacific Enterprises 


\begin{tabular}{|llllll|}
\hline \multicolumn{1}{|c|}{ GEOTHERMAL ELECTRIC POWER PLANTS OPERATIONAL, UNDER CONSTRUCTION, AND PLANNED } \\
IN THE UNITED STATES \\
(Hot Water Plants)
\end{tabular}

i Unocal subsidiary

j SCE original owner

- Includes 10 MWe SCE demonstration plant previously dismantled at Brawley

16 MWe expansion underway

m Expansion (6 MW each) of Del Ranch, Elmore and Leathers

n To be increased 


\begin{tabular}{|c|c|c|c|c|c|c|c|}
\hline \multicolumn{8}{|c|}{$\begin{array}{l}\text { GEOTHERMAL ELECTRIC POWER PLANTS OPERATIONAL, UNDER CONSTRUCTION, AND PLANNED } \\
\text { IN THE UNITED STATES } \\
\text { (Hot Water Plants) } \\
\end{array}$} \\
\hline $\begin{array}{l}\text { LOCATION } \\
\text { (State and Site) } \\
\end{array}$ & $\begin{array}{l}\text { PLANT } \\
\text { NAME }\end{array}$ & TYPE & $\begin{array}{l}\text { FIELD } \\
\text { DEVELOPER } \\
\end{array}$ & $\begin{array}{l}\text { PLANT } \\
\text { OWNER }\end{array}$ & UTILITY & $\begin{array}{l}\text { RATED } \\
\text { CAPACITY } \\
\text { (MW) }\end{array}$ & $\begin{array}{c}\text { YEAR } \\
\text { ON LINE }\end{array}$ \\
\hline \multicolumn{8}{|c|}{ CALIFORNIA (Cont'd) } \\
\hline & Amedee Geothermal & B & $\begin{array}{l}\text { Trans-Pacific } \\
\text { Geothermal Inc. } \\
\text { (TPG)/U.S. Energy } \\
\text { Corp. }\end{array}$ & TPG/U.S. & PG\&E & $2^{0}$ & 1988 \\
\hline & $\begin{array}{l}\text { Honey Lake Power } \\
\text { Facility }\end{array}$ & $\mathrm{B}^{\mathrm{p}}$ & GeoProducts Corp. & HL Power Co. & PG\&E & 309 & 1988 \\
\hline \multicolumn{8}{|l|}{ HAWAII } \\
\hline & $\begin{array}{l}\text { Puna Geothermal } \\
\text { Venture I }\end{array}$ & SF/B & OESI & OESI & HELCO & 25 & 1993 \\
\hline & $\begin{array}{l}\text { Kilauea Middle East } \\
\text { Rift }\end{array}$ & $\mathbf{S F}$ & $\begin{array}{l}\text { True Geothermal } \\
\text { Energy }\end{array}$ & $\begin{array}{l}\text { True/Mid-Pacific } \\
\text { Joint Venture }\end{array}$ & HELCO & 25 & 1995 \\
\hline & Puna II & SF/B & OESI & OESI & HELCO & 30 & TBD \\
\hline \multicolumn{8}{|l|}{ NEVADA } \\
\hline Beowrawe & Beowawe & DF & $\begin{array}{l}\text { California Energy } \\
\text { (originally Chevron) }\end{array}$ & $\begin{array}{l}\text { California } \\
\text { Energy/Crescent Valley } \\
\text { Goothermal }^{r}\end{array}$ & SCE & 15 & 1985 \\
\hline Brady-Hazen & Desert Peak & DF & $\begin{array}{l}\text { California Energy } \\
\text { (originally Phillips; } \\
\text { more recently } \\
\text { Chevron) }\end{array}$ & $\begin{array}{l}\text { California Energy } \\
\text { (originally Chevron) }\end{array}$ & SPP & 9 & 1985 \\
\hline Brady-Hazen & Brady Hot Springs I & DF & $\begin{array}{l}\text { Brady Power } \\
\text { Partners }\end{array}$ & Brady Power Partners & SPP & 20 & 1992 \\
\hline
\end{tabular}

- Phase II will add 3 MWe

p A co-generation plant using wood waste and geothermal heat; geothermal fluid used only to preheat boiler feedwater

q Hybrid wood-fired and geothermal

r SCE subsidiary 


\begin{tabular}{|c|c|c|c|c|c|c|c|}
\hline \multicolumn{8}{|c|}{$\begin{array}{l}\text { GEOTHERMAL ELECTRIC POWER PLANTS OPERATIONAL, UNDER CONSTRUCTION, AND FLANNED } \\
\text { IN THE UNITED STATES } \\
\text { (Hot Water Plants) }\end{array}$} \\
\hline $\begin{array}{l}\text { LOCATION } \\
\text { (State and Site) }\end{array}$ & $\begin{array}{l}\text { PLANT } \\
\text { NAME }\end{array}$ & TYPE & $\begin{array}{l}\text { FIELD } \\
\text { DEVELOPER }\end{array}$ & $\begin{array}{l}\text { PLANT } \\
\text { OWNER }\end{array}$ & UTHITY & $\begin{array}{l}\text { RATED } \\
\text { CAPACITY } \\
\text { (MW) }\end{array}$ & $\begin{array}{c}\text { YEAR } \\
\text { ON LINE }\end{array}$ \\
\hline \multicolumn{8}{|l|}{ NEVADA (Cont'd) } \\
\hline Fish Lake Valley & Fishlake I & TBD & Magma & Magma & SCE & 14 & 1996 \\
\hline (not on KGRA) & Fallon Navy Facility & TBD & TBD & TBD & TBD & 160 & $\begin{array}{l}1996 \\
\text { (est.) }\end{array}$ \\
\hline \multirow[t]{2}{*}{ Dixie Valley } & Oxbow & DF & $\begin{array}{l}\text { Oxbow Geothermal } \\
\text { (originally Sunedco; } \\
\text { then Trans-Pacific) }\end{array}$ & Oxbow & SCE & 50 & 1988 \\
\hline & Caithness I & DF & Caithness & Caithness & SCE & 19 & 1995 \\
\hline \multirow[t]{2}{*}{ Rye Patch } & Rye Patch A & B & OESI & OESI & SPP & 13 & TBD \\
\hline & Rye Patch B & B & OESI & OESI & SPP & 13 & TBD \\
\hline \multirow[t]{3}{*}{ San Emidio Desert } & $\begin{array}{l}\text { Empire Geothermal } \\
\text { Project }\end{array}$ & B & OESI & Empire Geothermal & SPP & 3 & 1987 \\
\hline & San Emidio I & B & $\begin{array}{l}\text { San Emidio } \\
\text { Resources }\end{array}$ & San Emidio Resources & SPP & 5 & 1994 \\
\hline & San Emidio II & B & $\begin{array}{l}\text { San Emidio } \\
\text { Resources }\end{array}$ & San Emidio Resources & SPP & 22 & 1995 \\
\hline \multirow[t]{4}{*}{ Steamboat Springs } & $\begin{array}{l}\text { Steamboat Geo- } \\
\text { thermal I }\end{array}$ & B & $\begin{array}{l}\text { Geothermal } \\
\text { Development } \\
\text { Associates } \\
\text { (GDA/OESI) }\end{array}$ & $\begin{array}{l}\text { Far West Electric } \\
\text { Energy Fund, Led. }\end{array}$ & SPP & 6.8 & 1986 \\
\hline & $\begin{array}{l}\text { Steamboat Geothermal } \\
\text { IA }\end{array}$ & B & OESI/GDA & Far West & SPP & 1.2 & 1989 \\
\hline & Yankee/Caithness & $\mathbf{S F}$ & Caithness/Sequs & Caithness/Sequa & SPP & $12^{3}$ & 1988 \\
\hline & Caithness Binary & B & Caithness & Caithness & SPP & 8 & 1994 \\
\hline
\end{tabular}

s An 8 MWe binary unit being added 


\begin{tabular}{|c|c|c|c|c|c|c|c|}
\hline \multicolumn{8}{|c|}{$\begin{array}{l}\text { GEOTHERMAL ELECTRIC POWER PLANTS OPERATIONAL, UNDER CONSTRUCTION, AND PLANNED } \\
\text { IN THE UNITED STATES } \\
\text { (Hot Water Plants) }\end{array}$} \\
\hline $\begin{array}{l}\text { LOCATION } \\
\text { (State and Site) }\end{array}$ & $\begin{array}{l}\text { PLANT } \\
\text { NAME }\end{array}$ & TYPE & $\begin{array}{l}\text { FIELD } \\
\text { DEVELOPER }\end{array}$ & $\begin{array}{l}\text { PLANT } \\
\text { OWNER }\end{array}$ & UTILITY & $\begin{array}{l}\text { RATED } \\
\text { CAPACITY } \\
\text { (MW) }\end{array}$ & $\begin{array}{c}\text { YEAR } \\
\text { ON LNE } \\
\end{array}$ \\
\hline \multirow[t]{3}{*}{ NEVADA (Cont'd) } & Steamboat 2 & B & $\begin{array}{l}\text { Steamboat } \\
\text { Development }\end{array}$ & Steamboat Development & SPP & 12 & 1992 \\
\hline & Steamboat 3 & B & $\begin{array}{l}\text { Steamboat } \\
\text { Development }\end{array}$ & Steamboat Development & SPP & 12 & 1993 \\
\hline & Steamboat 5 & B & Far West & Far West & SPP & 36 & 1996 \\
\hline \multirow[t]{3}{*}{ Stillwater/Soda Lake } & $\begin{array}{l}\text { Soda Lake Geothermal } \\
\text { Project }\end{array}$ & B & Chevron & $\begin{array}{l}\text { Institutional Investors } \\
\text { (OESI Operator) }\end{array}$ & SPP & 2.7 & 1987 \\
\hline & $\begin{array}{l}\text { Stillwater Geothermal } \\
\text { I Project }\end{array}$ & B & OESI & $\begin{array}{l}\text { OESI/Constellation } \\
\text { Development/Chrysler } \\
\text { Capital }\end{array}$ & SPP & 13 & 1989 \\
\hline & Sodu Lake II & B & Amor & OESI & SPP & 13 & 1990 \\
\hline $\begin{array}{l}\text { Wabuskat } \\
\text { OREGON }\end{array}$ & Wabuska & \multicolumn{6}{|c|}{ OREGON } \\
\hline Newberry Crater & NA & DF & California Energy & California Energy & $\begin{array}{l}\text { Eugene } \\
\text { Water \& } \\
\text { Eloctric; } \\
\text { BPA }^{\mathrm{e}}\end{array}$ & 30 & 1996 \\
\hline $\begin{array}{l}\text { Vale } \\
\text { UTAH }\end{array}$ & Vale I & DF & Transpacific & Transpacific & $\mathrm{BPA}^{\mathrm{e}}$ & 30 & 1996 \\
\hline Roosevelt Hot Springs & Blundell I & SF & $\begin{array}{l}\text { California Energy } \\
\text { Co. (originally } \\
\text { Phillips; } \\
\text { subsequently } \\
\text { Chevron) }\end{array}$ & $\begin{array}{l}\text { Utah Power Div. } \\
\text { (UPD) of PacificCorp }\end{array}$ & UPD & 20 & 1984 \\
\hline
\end{tabular}




\begin{tabular}{|c|c|c|c|c|c|c|c|}
\hline \multicolumn{8}{|c|}{$\begin{array}{l}\text { GEOTHERMAL ELECTRIC POWER PLANTS OPERATIONAL, UNDER CONSTRUCTION, AND PLANNED } \\
\text { IN THE UNITED STATES } \\
\text { (Hot Water Plants) }\end{array}$} \\
\hline $\begin{array}{l}\text { LOCATION } \\
\text { (State and Site) }\end{array}$ & $\begin{array}{l}\text { PLANT } \\
\text { NAME }\end{array}$ & TYPE & $\begin{array}{l}\text { FIELD } \\
\text { DEVELOPER }\end{array}$ & $\begin{array}{l}\text { PLANT } \\
\text { OWNER }\end{array}$ & UTILITY & $\begin{array}{l}\text { RATED } \\
\text { CAPACITY } \\
\text { (MW) }\end{array}$ & $\begin{array}{c}\text { YEAR } \\
\text { ON LNEE }\end{array}$ \\
\hline \multicolumn{8}{|l|}{ UTAH (Cont'd) } \\
\hline \multirow[t]{3}{*}{ Cove Fort-Sulphurdale } & $\begin{array}{l}\text { Cove Fort Geothermal } \\
\text { No. } 1\end{array}$ & B & Mother Earth & City of Provo & $\begin{array}{l}\text { Utah } \\
\text { Municipal } \\
\text { Power } \\
\text { Agency }\end{array}$ & 2 & 1985 \\
\hline & Cove Fort Steam Plant & DS & Mother Earth & City of Provo & $\begin{array}{l}\text { Provo } \\
\text { Power Co. }\end{array}$ & 2 & 1988 \\
\hline & $\begin{array}{l}\text { Cove Fort Steam } \\
\text { No. } 2\end{array}$ & DS & Mother Earth & City of Provo & $\begin{array}{l}\text { Provo } \\
\text { Power Co. }\end{array}$ & 7 & 1989 \\
\hline
\end{tabular}


NEVADA KGRA'S RECLASSIFIED

The Bureau of Land Management's Nevada State Office has made major changes in the Known Geothermal Resources Areas (KGRAs) in that state. The KGRAs are established on the basis of "geology, nearby discoveries, competitive interests, or other indicia" that tend "to warrant expenditures of money" for geothermal exploitation (Geothermal Steam Act 1970, P.L. 91-581).

Four additional KGRAs have been designated, or in one case redesignated, in Nevada. They include:

- Fish Lake Valley, where a commercial geothermal well was completed in 1984. This prospect is in Esmerelda County about 45 miles west of Tonapah and about 40 miles from Bishop, California, where transmission lines are available for carrying power to Southern California markets. Magma Power Co. has completed additional commercial wells and has initiated permitting for a $14 \mathrm{MWe}$ plant for the area to be operational in 1995.

- New York Canyon, which abuts the Dixie Valley KGRA where the 50 MWe Oxbow plant is located.

- Round Mountain, where Round Mountain Gold Corp. is utilizing geothermal resources during winter months to improve the efficiency of the mine's heap leaching process.
- Salt Wells, which was one of the original KGRAs designated by USGS, but which was eventually declassified after it was offered for lease sale twice, and no bids were received. Its new status is due to a commercial discovery in the area in 1985. It is located in Churchill County, approximately 60 miles from Reno.

(The site of proposed Navy development near fallon is not on a designated KGRA.)

The new KGRA list for Nevada also separates the original Brady-Hazen and Stillwater-Soda Lake into two separate KGRAs each, with some changes in boundaries. The original designations that remain on the list, although with boundary changes in some instances, include:
- Beowawe
- Dixie Valley
- Gerlach
- Rye Patch
- San Emedio Desert
- Steamboat Springs

The declassified KGRAs include:
- Baltazor
- Moana Springs
- Colado
- Pinto Hot Springs
- Double Hot Springs
- Ruby Valley
- Elko Hot Springs
- Soldier Meadow
- Fly Ranch
- Trego 
- Hot Springs Point

- Warm Springs

- Kyle Hot Springs

- Wilson Hot Springs

- Leach Hot Springs

According to USGS Circular 790 and other data sources, the temperature of the geothermal fluids in about half of these declassified areas is below $125^{\circ} \mathrm{C}\left(257^{\circ} \mathrm{F}\right)$, and several were originally designated only because the lands applied for overlapped by 50 percent in two or more noncompetitive lease applications, as initially required by the Steam Act. Little serious developer interest has been shown in most such areas. Further information may be obtained from:

Richard W. Hoops

Bureau of Land Management

MS-NV920

850 Harvard Way

Reno, NV 89502

(702) $785-6568$

\section{NEWBERRY KGRA ENLARGED}

Effective September 15, 1993, an aggregate of 13,345 areas was added to the Newberry Caldera KGRA in Oregon. The lands include:

\section{Williamette Meridian}

T. 21S, R. 13E, Secs. 7,8, and 9

T. 22S, R. $13 E$, Sec. 18

T. 21S, R. 12E, Secs. 9,10,12,16,17,20, and 30 through 32
T. 22S, R. $12 \mathrm{E}$, Secs. $5,6,8$, and 13 through 16

All available land within this KGRA can be leased only through a competitive lease sale, but existing leases will not be affected.

For further information contract:

Jack Feuer

BLM Oregon State Office

Division of Mineral Resources

P.O. Box 2965

Portland, OR 97208-2965

(503) 280-7043

\section{ANADARKO ANNOUNCES SUC- CESSFUL GEOTHERMAL WELL}

Anadarko Petroleum Corp. today announced the successful testing of an offset observation well at its 1989 geothermal discovery in the Pueblo Valley of southeast Oregon. Located in the Alvord KGRA, the well reached a total depth of 2,376 feet, and 4 1/2-inch casing was set to 1,007 feet. The well flowed at an average rate of 290 gallons per minute with a wellhead temperature of $148^{\circ} \mathrm{C}$ $\left(296^{\circ} \mathrm{F}\right)$. Both the discovery well and the offset well were completed for long-term observation of reservoir temperatures and pressures during possible development of the field for electric power generation using binary (closed system) power plants.

Anadarko holds 8,120 net lease acres at the Pueblo Valley discovery site and an additional 39,485 net lease acres within the Alvord KGRA. Anadarko maintains an 
active interest in geothermal energy because of its long-term potential for economic power.

Source: Anadarko Press Release 11/12/93

\section{PLANNING FOR NATIONAL EFFORT TO DEVELOP INNOVATIVE DRILLING TECHNOLOGIES UNDERWAY}

At the behest of DOE's Geothermal Division, efforts are underway to seek improved drilling technologies through coordinating the interests of several industries, Federal agencies, and academia in a National Advanced Drilling and Excavation Technologies Program (NADET). A steering committee for the planning of this effort has been established under the auspices of the Energy Laboratory of the Massachusetts Institute of Technology, headed by Jefferson Tester, director of the Laboratory. The committee's report is nearing completion, and will be published in the near future.

In addition, two boards of the National Research Council, the Geotechnical Board and the Board on Earth Sciences and Resources, have been enlisted by DOE to study the feasibility of revolutionary advances in fundamental rock drilling technologies. The boards jointly formed a new committee on Advanced Drilling Technologies, chaired by Ali Argon, Massachusetts Institute of Technology, which includes experts from both industry and academia with specialties in a broad range of engineering and scientific disciplines related to drilling and excavation.
The committee held a workshop April 14-15, 1993, to elicit ideas and commentary from experts. Fifty participants from industry, government, and academia attended. The first day's session reviewed the state-of-the-art physics of rock fracture, drilling techniques (conventional and unconventional), muds and borehole stability, and other related technologies. The second day's session addressed such topics as:

- What is being done well now?

- What problems can be addressed by targeted R\&D?

- What are revolutionary or "breakthrough" concepts/technologies that could make a significant difference in the ability to drill holes?

The committee's report is due in February 1994.

Although reduced drilling costs will perhaps most significantly affect the future of geothermal development, other industries have a strong interest as well. Those participating in preliminary meetings on the subject and committee activities include, in addition to the geothermal industry, the drilling industry itself, oil and gas, mining, waste disposal, tunneling, and gr sundwater interests. In response to a DOE questionnaire, substantive industry support was indicated including financial contributions, experience/personnel, equipment, laboratory facilities, and data and field testing facilities. 


\section{SLIM HOLE DRILLING} TESTS UNDERWÄY

As reported in GPM No. 14, a government/industry group has initiated a project to determine whether a geothermal reservoir can be sufficiently evaluated to satisfy the requirements of the investment community with data collected in slim holes in lieu of the costly production-size wells required with today's technology. The significance of this effort is that the $\$ 1.5$ to $\$ 3.5$ million cost of large rotarydrilled wells requires a long period of debt service before the costs can be recaptured from power sales; if slim holes are proved effective, production drilling can be delayed until the power plant is under construrtion, saving years of interest payments.

In addition, the relatively benign environmental presence of slim holes will be critical to the public acceptance of development in scenic areas of the Pacific Northwest. Smaller equipment is also especially appropriate for geothermal exploration in developing countries or wherever financial and institutional support are minimal. This DOE-funded effort, headed by Sandia National Laboratories, is working toward several tools for slim hole exploration that would be accessible to the small, independent geothermal developer. They include, but are not limited to:

- guidelines for drilling and completing exploration slim holes

- recommended test procedures and strategies, including data requirements, for the slim holes
- improved downhole instrumentation to collect needed data and data interpretation techniques

A major methodology in determining the efficiency of the slim hole approach is to drill a corehole in a producing field where the results can be compared with actual production data. At this writing, the first test hole on the premises of the $24 \mathrm{MWe}$ Far West plant at Steamboat Hills, Nevada, is nearing completion at 3,650 feet, below current production zones. Earlier flow and injection tests of Far West's existing coreholes, with accompanying pressuretemperature-spinner logs, yielded flow data that were in excellent agreement with results obtained by using measured downhole conditions as input for wellbore simulator codes. This is necessary for extension of specific results at a wellcharacterized reservoir such as Steamboat Hills to a more general predictive capability.

The downhole instrumentation under development includes a suite of memory logging tools for slim hole high-temperature application. The first tool will measure pressure and temperature and is especially designed to be a low-cost, but very precise, device. This tool will be smart in the sense that it can make "decisions" downhole.

A second tool will measure the gamma ray emissions from formation material, and it will be an indicator of lithology. A fluid sampling tool will complement the spectral gamma tool in that it will further constrain the lithology by identifying dissolved formation materials. Plans are being made to integrate the tool responses into formation parameters of interest through 
cooperation efforts between geothermal operators and scientific drilling programs.

\section{PROGRESS CONTINUES IN LOST CIR- CULATION CONTROL TECHNIQUES}

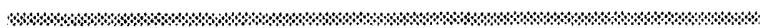

Working in close cooperation with each other, the Lost Circulation Technology Development Program at Sandia and the Geothermal Materials Project at Brookhaven National Laboratory report continued progress in techniques to control loss of circulation in geothermal well drilling. Lost circulation is the most costly problem routinely encountered in geothermal drilling, and it may account for as much as 3.5 to 10 percent of the total costs of a typical geothermal project.

In a major technology transfer activity, Sandia has established a rolling float meter loan program in order to obtain independent evaluation of this device by the industries that would ultimately use it in drilling operations. The meter was developed in 1991-92 to provide a method for accurately measuring drilling fluid outflow rates that can advise the driller of lost circulation as it occurs, the magnitude of the loss, its location, and possible treatment. To foster the interest and transfer of the technology to industry, seven rolling float meter units were fabricated and loaned to seven different service companies in both the geothermal and petroleum drilling industries. One of the companies built an additional five units to expand its field testing program. If the test results are favorable, Sandia will continue working with industry to determine the ability of the meter and, possibly, to develop a manufacturing capability for its widespread distribution.

In seeking optimum methods for emplacement of materials to plug lost circulation zones, the drillable straddle packer concept has been found feasible, and the performance design goal for the packer's fabric bags was achieved. The purpose of this equipment is to maximize the volume of cement delivered to the loss zone while minimizing the volume of cement remaining in the wellbore. It differs from conventional packers in three respects:

- the drillable straddle packer is inflated simply, without the use of downhole valving.

- it is designed to provide lowpressure (30-psi) sealing capability, instead of the high-pressure ( 2000-psi) requirements of conventional packers.

- it is fabricated of low-cost, drillable materials and is designed to be left in the bottom of the wellbore after the cementing operation and to be drilled through upon the resumption of drilling after the cement sets.

A Packer Demonstration Facility is being constructed in order to demonstrate the drillable straddle packer and its zonal isolation capabilities with cement at full scale. The cement to be used is an advanced chemical formulation developed by the Materials Project at BNL. The most promising formulation identified to date consists of mixtures of magnesium oxide, bentonite, ammodium polyphosphate, and 
borax. Depending on the placement temperature, the pumpability can be controlled by varying the magnesium oxide and borax concentrations. At placement temperatures above $60^{\circ} \mathrm{C}\left(140^{\circ} \mathrm{F}\right)$, microencapsulation of the magnesium oxide in organic compounds such as waxes, epoxies, or polyethylene is generally needed to extend the pumping time for more than two hours.

Preliminary results of tests of three formulations based on calcium compounds indicate that they may be easier to place than the magnesium-oxide based cement and may yield higher strength, more durable products. After further laboratory experiments, the most promising formulations will be selected for optimization with respect to various placement methods and formation conditions. They will be subjected to the larger scale flow and mud displacement tests at Sandia.

Other materials for geothermal use under development include advanced hightemperaturelightweight cements, thermally conductive polymer cement liners, hightemperature chemical coupling systems, and materials for mitigating corrosion at The Geysers.

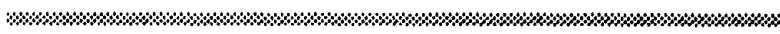

MAGMA ACQUIRES STRATEGICALLY LOCATED SALTON SEA GEOTHERMAL ACREAGE

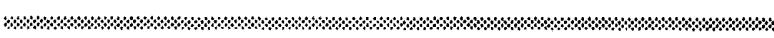

Magma Power Co. has acquired from Freeport McMoRan Resource Partners approximately 17,000 acres of geothermal leaseholds at the Salton Sea KGRA in
Southern California's Imperial Valley. This acquisition, coupled with Magma's existing leasehold acreage at the Salton Sea and the geothermal acreage purchased from Unocal in March of this year, will enable Magma to manage the Salton Sea reservoir as a single unit. In addition to being highly productive, the Salton Sea KGRA is strategically located near the major Southern California markets of Los Angeles and San Diego. Magma also owns geothermal leases on three other KGRAs in the Imperial Valley.

Magma plans to submit proposals for new geothermal power projects at the Salton Sea reservoir in response to Requests for Bids (RFBs) issued on August 11 by Southern California Edison and San Diego Gas \& Electric Co. The RFBs, issued under the California Public Utility Commission's Biennial Resource Plan Update, set aside $275 \mathrm{MW}$ of new generating capacity from renewable energy sources such as geothermal.

"This additional acreage significantly enhances our ability to develop new geothermal projects at the Salton Sea under the BRPU," stated Paul M. Pankratz, Magma chairman and chief executive officer. "We are especially well-positioned to bid on the new generating capacity scheduled to come on stream in Southern California beginning in 1997. This new acreage includes several prime geothermal properties, as well as potential sites for future geothermal plants and facilities."

Source: Magma Power Co. Press Release 10/18/93 
\%०

\section{U.S. FOREST SERVICE FINALIZES SWAP OF GEOTHERMAL LEASES}

In January of 1993, the Deschutes National Forest announced that it had completed a two-year effort to exchange geothermal leases in the Newberry National Volcanic Monument for leases outside monument boundaries. Vulcan Power of Santa Rosa, California, was the last company to be compensated by the Bendbased forest for relinquishing a lease site in the monument. Vulcan's last lease, covering 900 acres, was about seven miles south of the High Desert near the Lava Cast Forest. The legislation that created the monument in 1991 prohibits drilling for hot water within its borders, which stretch from Lava Island Falls on the Deschutes River southeast to the Newberry caldera.

The Deshutes management compensated geothermal interests, which together held 10,448 acres in the monument, with 6,088 acres outside the monument. The exchange was based on heat value, not land area. Most of the new leases are adjacent to the flanks of the Newberry caldera, which frames East and Paulina Lakes.

\section{UNOCAL SELLS GLASS MOUNTAIN LEASES}

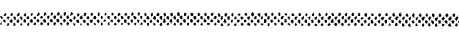

As reported in a related article in INDUSTRY SCENE, Unocal has sold its interest in 41,000 acres of geothermal leases in the Glass Mountain-Medicine Lake geothermal field to the California Energy Co. This young volcanic area, located in northern California near the Oregon border, has been estimated to be a "giant" geothermal field of over 1,000 MWe generating potential.

The USGS and national laboratories were funded by DOE to support Unocal in determining the extent of the resource in the area by conducting a large-scale, stateof-the-art seismic experiment. Analysis of the seismic results indicates that large areas of the Medicine Lake Caldera lie over hydrothermal systems. The University of Utah Research Institute, also funded by DOE, has investigated the hydrothermal changes in core from Unocal and Freeport McMoRan wells to determine the evolution of the geothermal field.

This site is under consideration for the third of the BPA geothermal demonstration plants in the Northwest. 


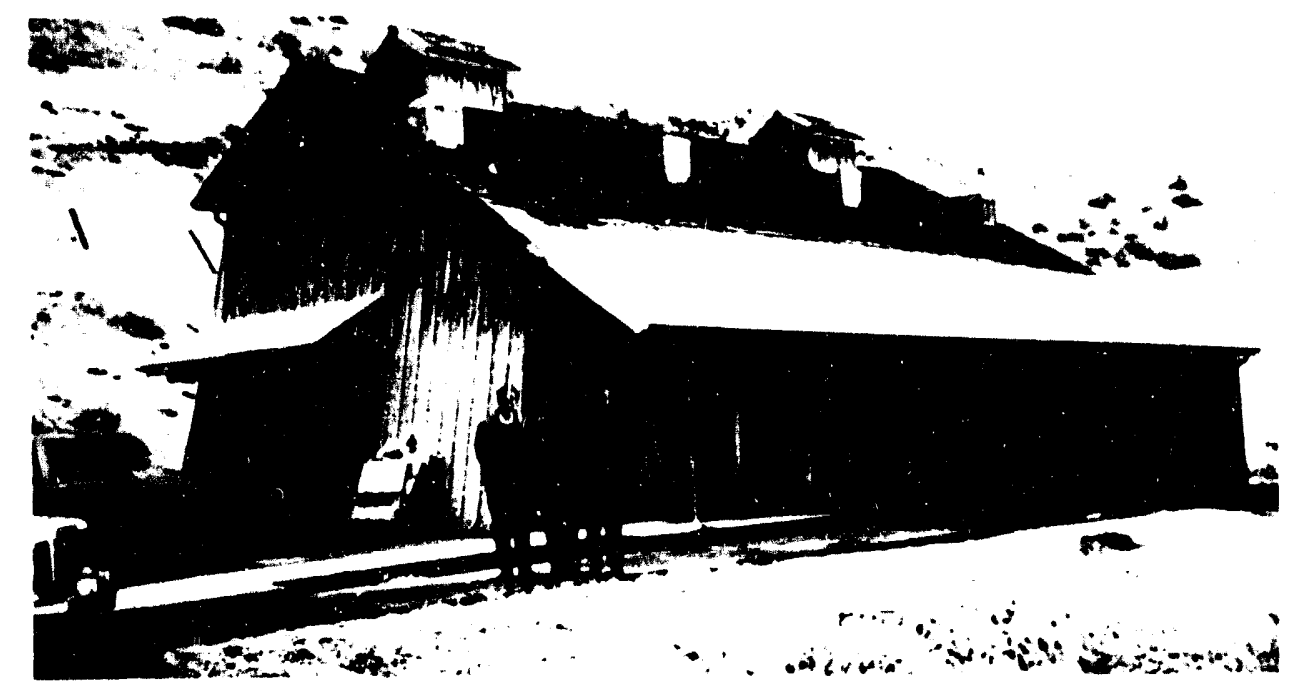

Boise Warm Springs Water District System

A Century of Service

In operation since 1892, the system still uses the original wells. Original well house (above) is in the National Register of Historic Buildings. It was constructed by cutting off the tops of the original wood well drilling derricks and enclosing the framework. (GRC Bulletin 11/92) 


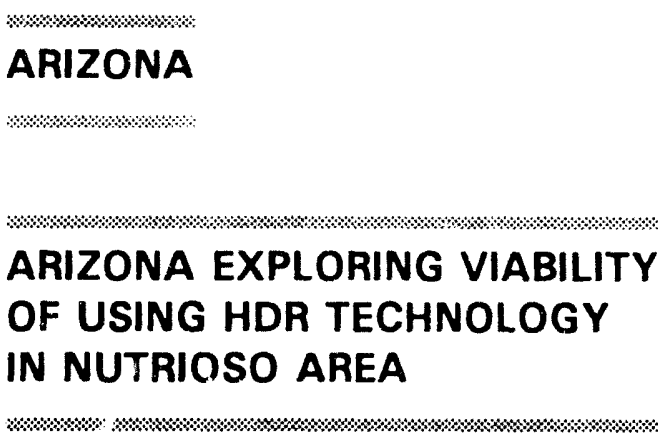

Using DOE/state 50-50 cost-shared funding, the state of Arizona is investigating the hot dry rock potential in the Nutrioso area of east-central Arizona. An exploratory well was drilled near Alpine from which core samples and temperature and borehole logs will be analyzed to determine the suitability of the Springerville/Alpine area for future geothermal development as a hot dry rock site.

At the end of August 1993, the well had reached a bottomhole depth of 4,500 feet using core drilling, and over 90 percent of the core had been successfully recovered; however, the basement rock was not penetrated. The State of Arizona is in dialogue with the USGS in anticipation that it will assume responsibility for the well. Should such an arrangement materialize, the well will be left so it can be re-entered at a later date. Drilling and analyses are being conducted by a team consisting of Tonto Drilling Co., researchers from New Mexico State University, and USGS. DOE provided a $\$ 327,000$ grant to the state for the Federal share of the project in accordance with the 1991 direction of Congress.

\section{CALIFORNIA}

असेकिसे

\section{ACTIVITIES DESIGNED TO EXPAND GEOTHERMAL DIRECT USE CONTINUE IN SEVERAL COMMUNITIES}

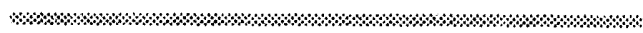

Several California communities are undertaking to expand the use of geothermal energy in existing direct use projects or to initiate new ones. An evaluation of the reservoir underlying the adjacent cities of San Bernardino and Colton is underway to determine the extent of the reservoir -- already used by San Bernardino for a 27-building downtown district heating system -- in terms of its capacity to sustain further geothermal development in the area. If it is found to be large, it could become a regional resource, usable by other cities to develop district heating systems. This effort is funded by the California Energy Commission.

The state's Geothermal Grant and Loan Program is funding a resource assessment for the City of Twentynine Palms in the Mojave Desert. One test well produced fluids of $50^{\circ} \mathrm{C}\left(123^{\circ} \mathrm{F}\right)$, hot enough to be used in a district heating/cooling system or in other direct use applications. In Phase II, further drilling will be undertaken and a survey of potential users and retrofit requirements will be made.

In Alturas, the well used to heat most of the high school campus was deepened by about 500 feet, and the increased 
production of about 50 to 80 gallons per minute will provide heat for additional classrooms and the agricultural shop area. Interference tests are being conducted on this well and one used to heat the elementary and middle schools. Conventional electrical use tests are being metered for a year at the three schools to compare and calculate the repayment schedule based on savings between the systems. Final design work on the space heating system will complete the project.

Phase II is underway at the Lake County Geothermal-Agricultural Heat Center, a facility developed by the county to promote greenhouse agriculture. Phase I was a joint venture between the county and the Mendocino-Lake Community College District to demonstrate technical feasibility, with the college using the greenhouse as a teaching facility. Phase II will expand the center to demunstrate commercial feasibility. An additional well will be brought into production, and about 80,000 square feet of greenhouse capacity will be available for commercial use. A marketing program is underway to attract greenhouse operators.

Source: Geo-Heat Center Quarterly Progress Report 1-3/93

\section{LAKE COUNTY LAUDED FOR CLEANEST AIR}

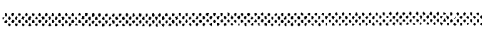

On December 10, 1992, the California Air Resources Board recognized Lake County, California, for having the cleanest air in the state for the third year in a row. No other air basin in California met the strict standards of the board, standards that are more rigid than those of the Federal Clean Air Act.

The Board attributed local air quality management success to three elements -control technologies used in geothermal and mining industries, a successful burn ban during smog season, and an improved open burning program. The geothermal industry, along with the California Department of Forestry and Fire Protection and area residents, has voluntarily complied with air quality guidelines.

Source: Geothermal Resources Council Bulletin 3/93

\section{MODOC HIGH SCHOOL SAVES $\$ 7,000$ PER MONTH ON HEATING COSTS}

The local high school in Alturas, California, is saving $\$ 7,000$ per month on heating costs by using a geothermal resource to heat classes efficiently and provide hot showers in the gymnasium. The geothermal system at Modoc High School in Modoc County can pump as much as 400 gallons per minute (gpm) of water from its well. Although temperatures fluctuate, the well water temperature can reach $66^{\circ} \mathrm{C}\left(150^{\circ} \mathrm{F}\right)$, and the outside temperature can drop to almost $-37^{\circ} \mathrm{C}\left(-35^{\circ} \mathrm{F}\right)$. The well is almost 2,000 feer deep. The pump is located 320 feet below ground level, and the water level is situated only 160 feet below the surface.

Source: Geothermal Resources Council Bulletin 2/93 


\section{IDAHO}

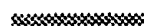

\section{GEOTHERMAL ALLIGATOR FARM IN IDAHO; EXPANSION TO CATFISH PLANNED}

An alligator and catfish farm using geothermal waters is being developed in the Raft River area of Cassia County, Idaho. Garland Larson plans to raise thousands of alligators and to eventually produce six million pounds of processed catfish per year.

The alligators will provide meat and skins. It is expected that carcasses of farm animals and chemical high-protein fodder will be used for feed. A hatchling alligator takes about two years to reach a six-foot length.

Source: Geo-Heat Center Quarterly Project Progress Report 7-9/93

\section{\%}

\section{MASSACHUSETTS}

\%\$\$

\section{\%\$\$ \\ BOSTON EDISON BREAKS NEW GROUND WITH GEOTHERMAL PROJECT}

A large, energy-efficient geothermal heat pump system is being installed in a new Boston housing complex thanks to an innovative marketing program administered by Boston Edison, the local utility. The advanced GHP system, which will use three 1,500-foot standing-column wells, will provide heating, cooling, and water heating for the 123-unit St. Cecilia's House elderly housing development being built for the Archdiocese of Boston.

Through the utility's Energy Crafted Home (ECH) demand-side management program, the archdiocese will receive approximately $\$ 178,000$ in incentives to apply to the cost of the geothermal system and other new-construction shell measures such as increased insulation and highefficiency windows and lighting.

The ECH program was developed by Boston Edison and other New England utilities to encourage energy efficiency in new construction. The program offers training and cash incentives to builders, architects, and engineers who design and build houses that meet ECH standards. As a result, $\mathrm{ECH}$ construction produces an energy savings of 40 to 50 percent compared with standard code-built construction.

Source: Geo-Heat Center Quarterly Project Progress Report 7-9/93

\section{NEVADA}

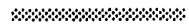

\section{GEOTHERMAL DEHYDRATION PLANT BEING BUILT AT EMPIRE}

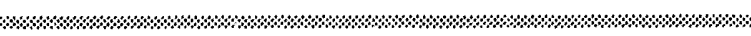

Integrated Ingredient, a large food processing company, is building a new state-of-the-art plant for vegetable 
processing at Empire, Nevada. The plant will feature the processing and year-round storage of dehydrated onion and garlic products. Geothermal resources will supply the heat for dehydration. The new facility will enable the company to produce its current industrial and consumer requirements at a considerable cost savings over purchasing garlic and onion externally.

Acquisition of Durkee-French by Burns Philip Food Inc., a marketing arm of Integrated Ingredient, has greatly increased the company's requirements for onion and garlic, two of the most popular spices in North America.

Source: Geo-Heat Center Quarterly Project Progress report 7-9/93

\section{NEW MEXICO}

\%\$\%\$\%\$\%\$\%\%

\section{SMALL GEOTHERMAL POWER UNITS BOUGHT FOR NEW MEXICO GREENHOUSE}

In April 1993 Dale Burgett, owner of Burgett Geothermal Greenhouses, Inc., of Animas, New Mexico, purchased three 400 kWe modular binary units that were tested in Hammersly Canyon near Lakeview, Oregon, a number of years ago. The heat exchangers were constructed by Sun Power Systems (SPS) and are equipped with OESI turbines.

Burgett installed these units to replace the diesel-powered generators used to power the greenhouse operations. He believes that they will generate power in the range of $2-3 \xi / \mathrm{kWh}$. Burgett previously operated a $40 \mathrm{kWe}$ trailer-mounted SPS unit for a short time, which he considers a learning prelude to operation of the three new units.

The greenhouse facility is approximately 14 to 15 miles southwest of Lordsburg, partly in the Lightning Dock KGRA.

Source: Geothermal Resources Council Bulletin 5/93

\section{NEW YORK}

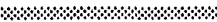

\section{UTILITIES ASSESSING GEO- THERMAL DEVELOPMENT POTENTIAL IN UPSTATE NEW YORK}

Three major New York utilities are investigating geothermal energy opportunities in upstate New York. The utilities, Niagara Mohawk Power Corporation based in Syracuse, New York State Electric and Gas based in Binghamton, and Rochester Gas and Electric Corp., service almost all of New York except metropolitan New York City. The technical and economic status of largescale geothermal systems will be studied and the energy production potential of geothermal resources in New York assessed. The utilities are primarily interested in geothermal electricity generation, but large-scale direct use applications may also be examined. These 
geothermal supply-side options will be incorporated into the utilities' planning process and evaluated with the other supply- and demand-side options available to them.

\section{OREGON}

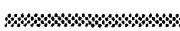

\section{OREGON OFFERS TAX BREAK TO USERS OF RENEWABLE ENERGY}

Early in 1993 city officials in Klamath Falls, Oregon, encouraged property owners to move quickly to take advantage of the state's Business Energy Tax Credit designed to encourage investment in energy-saving technology, recycling, and conversion to renewable energy sources, such as geothermal, for heating homes and businesses. Through tax credits, the state will reimburse 35 percent of the investment of property owners for these purposes over a period of five years, giving downtown businesses an extra incentive to explore the use of geothermal energy

Thus, the city solicited interest in using the downtown geothermal district heating system and offered help through the GeoHeat Center at the Oregon Institute of Technology in determining the savings that could be achieved by switching to the system. (See related article below.)

The number of projects that would be accepted for state tax credits was limited, however, and funding for the 1993 program was likely to be claimed in a matter of weeks. Further, the tax credit program may be sharply curtailed or even eliminated in the future.

Investments in use of geothermal energy for heating have always won easy approval from state officials for the tax credit program. The Oregon Department of Energy also offers a small-scale loan program for businesses and homeowners who want to invest in energy conservation projects.

For additional information about the Oregon State Tax Credit and Loans program, contact Kent Colahan, Klamath Falls Geothermal Superintendent, phone (503) 883-5363.

Source: Geothermal Resources Council Bulletin 3/93 


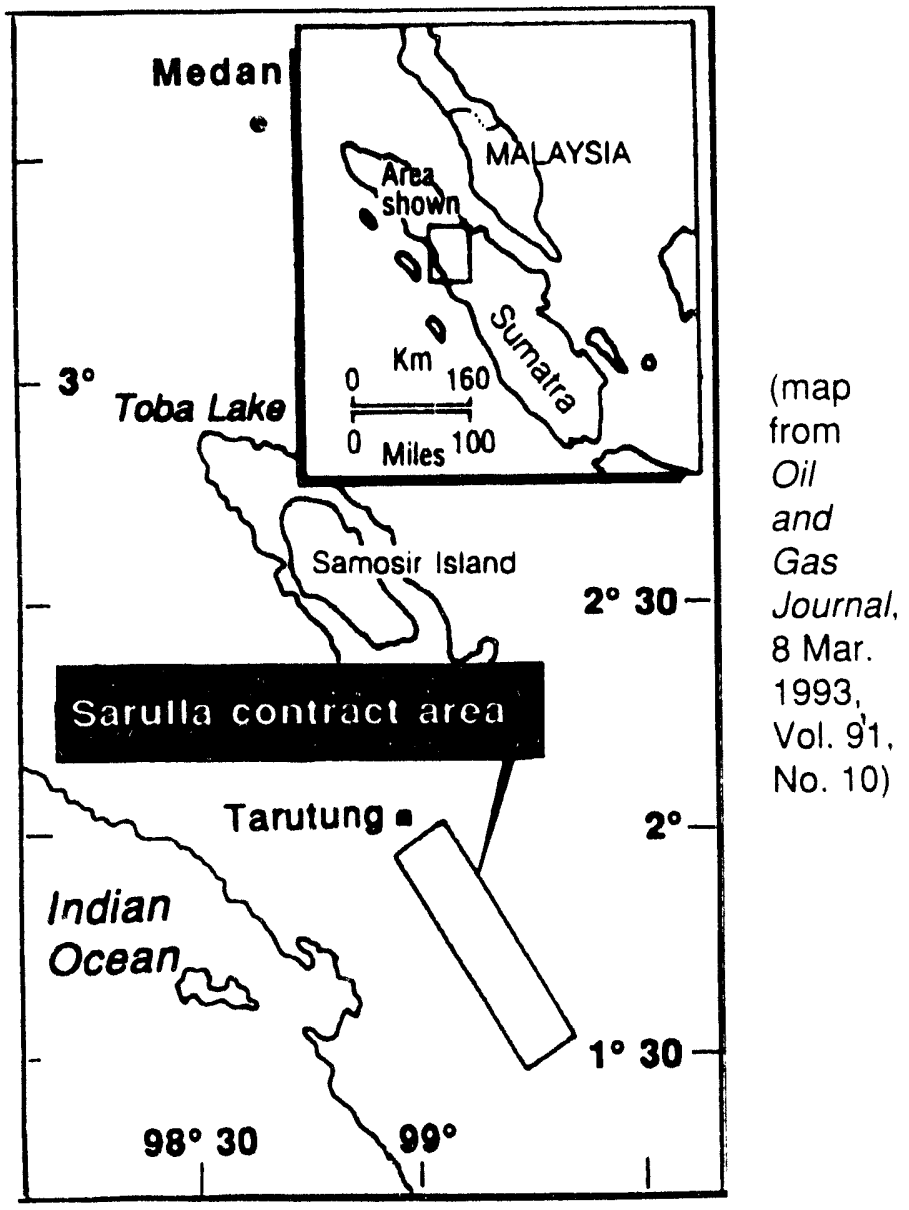

UNOCAL SARULLA CONTRACT AREA

The Sarulla Contract Area in northwestern Sumatra is about 39 miles long, and 10 miles wide, encompassing approximately 240,000 acres. It is located near Lake Toba, about 300 miles south of Medan, Sumatra's most populous city. PLN has an existing power grid near the Sarulia Block. Given Sarulla's proximity to Medan and Sumatra's growing demand for electricity, a substantial market already exists for the power to be generated. The Indonesian government believes that this project will be an important contributor to Indonesia's growing economy and will be of significant help in meeting the nation's increasing electricity demand. 


\section{UNOCAL TO DEVELOP MAJOR GEOTHERMAL RESOURCE IN INDONESIA}

On February 27, 1993, the government of Indonesia announced a contract for development of the Sarulla geothermal field in northern Sumatra. The contract was signed by the Unocal Corporation, in agreement with Pertamina, the Indonesian national oil company, and PLN, the national electric utility company, to generate up to $1,000 \mathrm{MW}$ of electricity from geothermal steam and to deliver the electrical power to PLN's transmission system.

Under the terms of the agreements, Unocal North Sumatra Geothermal Ltd., a subsidiary of the Unocal Corporation, will be responsible for all aspects of development, including drilling, steam production, and power plant financing, construction, and operation. The agreements cover a 42-year period, including time for exploration and development of the reserves; Unocal will supply steam for 30 years to power plants that will be built as reserves are proven. Exploration is to begin at once to develop up to $330 \mathrm{MWe}$ at Sarulla with an initial $110 \mathrm{MWe}$ plant anticipated to go on line in 1999.

After 12 years of ownership and operation, Unocal will transfer ownership of the power plants to PLN, but will continue to supply steam. In addition to payment for steam, Unocal will receive a cost-plus-fee payment for construction, operation, and maintenance of the power plants.
According to Unocal, the Sarulla Block contains some of the best geothermal prospects in the world. The company remains hopeful that these prospects will support more than $1,000 \mathrm{MWe}$ of generating capacity, which would be the energy equivalent of more than $\mathbf{3 0 0}$ million barrels of oil. Reiterating the fact that geothermal energy is a core business for Unocal, the Sarulla project could significantly enhance the company's position as the world's largest developer of geothermal energy.

Presently, Unocal is the developer of the Salak geothermal field in west Java, where power plants totalling $110 \mathrm{MWe}$ are under construction. The Government of Indonesia also announced its intention to develop other geothermal fields on the island of Java, Sumatra, Suluwesi, Flores, and Ambon, utilizing both public and private financing, and allowing private ownership of power plants and transmission links.

Source: Geothermal Resources Council Bulletin 3/93

\section{MAJOR GEOTHERMAL DEVELOPMENT CONTINUES IN PHILIPPINES}

On March 11, 1993, the Philippine government announced that geothermal will be the country's largest domestic energy source by the year 2000 . The National Power Corporation (NPC) has recently revised its power development plan for 1993-2005 to include an additional $1,673 \mathrm{MWe}$ of geothermal capacity, and 
President Fidel Ramos has urged that the geothermal project be accelerated, prompting the search for private investors for projects. A six-page report released by the U.S. Embassy describes specific projects in the NPC plan and the likely prospects for private investment.

Power Distribution by Submarine Cable - A First

In 1991, the Palinpinon geothermal power plant located in Negras Oriental was connected to Panay island by submarine cable -- a first in power distribution. The Negros-Panay grid is currently being connected to the Cebu grid, and by 1997. the Cebu grid will be connected to the Leyte-Samar grid, which is anchored in the Tongonan geothermal plant. These developments constitute the first three major electric interconnections of islands by submarine cable. They give Cebu, the fastest growing commercial center in the Visayan Islands, access to the abundant geothermal resources of Palinpinon and Tongonan. Conversely, the Cebu connection opens the two geothermal fields to a bigger market and consequently to greater opportunities for development.

\section{New Capacity at Tongonan}

The Philippine National Oil Co. (PNOC) is investing about $\$ 230$ million in a 163 MWe project in Tongonan, Leyte -- $\$ 80$ million for field development and $\$ 150$ million for power plant construction. Under a memorandum of understanding with NPC, PNOC will construct the power plant, and NPC will install the transmission line to Cebu. This is PNOC's first venture into actual plant power generation -- NPC's usual role -- and up to now PNOC has only developed the field and sold the resource to NPC.

As part of the country's Build-OwnOperate-Transfer (BOOT) program designed to induce foreign investment, Magma Power Co. has been selected to build and operate the $70 \mathrm{MWe}$ plant, transferring ownership to PNOC in 15 years. The project is part of the $\$ 1.6$ billion project aimed to generate 595-665 $\mathrm{MWe}$ of geothermal power in Leyte. The World Bank has committed up to $\$ 500$ million in financing. PNOC hopes to bring $225 \mathrm{MWe}$ to Cebu via cable by 1996, and the additional $440 \mathrm{MWe}$ to the Luzon grid by 1997.

\section{New Capacity at Palinpinon}

The first Palinpinon plant (1 15.5 MWe) started operation in 1983, but remained under-utilized until 1990 when power demand rose with the operation of the Negros-Panay cable. A second plant at 80 MWe is bringing the field total to 195.5 MWe. In accordance with the 1991 Philippine Energy Plan, an additional 40 MWe will be added to Palinpinon capacity and another $40 \mathrm{MWe}$ to the Murcia plant in Mambucal, Negros Occidental.

New Capacity at Bacon-Manito.

A total of 150 MWe of new capacity -Bac-Man I at $110 \mathrm{MWe}$ and two $20 \mathrm{MWe}$ modular plants (Bac-Man II) -- at the BaconManito geothermal site will ease the power crisis of the Luzon grid. The project, which took 10 years to explore and develop, will 
generate base load power at only a fraction of the cost of oil or coal and will reduce the country's dependence on imported oil by $\$ 31.5$ million per year.

Source: Geothermal Resources Council Bulletin 3/93; GA News 11-12/92; 1-3/93

\section{GEOTHERMEX AND ELECTROCONSULT WIN COSTA RICA GEOTHERMAL CONTRACTS}

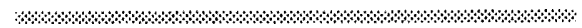

In January 1993, the Instituto Costarricense de Electricidad (ICE), the national electric utility of Costa Rica, announced the selection of consultants for its Miravalles II geothermal project. GeothermEx, Inc., Richmond, California, was selected as a result of international competitive bidding to perform the geothermal field engineering and Electroconsult, of Milan, Italy, was selected to perform the project engineering leading to the construction of a planned $55 \mathrm{MWe}$ geothermal power plant. In addition, GeothermEx is to perform field exploration and engineering services for as-yetunspecified new geothermal fields in Costa Rica. GeothermEx previously worked with ICE during the period 1975-1981, when the Miravalles field was discovered through deep exploratory drilling. Electroconsult has worked subsequently with ICE during the phase of design and engineering for the Miravalles 1 power plant. That $55 \mathrm{MWe}$ plant is scheduled to come on line in 1994. The Miravalles II project is financed by a loan from the Inter American Development Bank, Washington, DC, as was the Miravalles I project.

Source: Geothermal Resources Council Bulletin 3/93

\section{EEC AID PACKAGE TO GREECE INCLUDES 50 MWE GEOTHERMAL DEVELOPMENT}

The U.S. Embassy in Athens reports that the European Economic Community (EEC) has approved an ECU 20 billion aid package to Greece. The Embassy listing of major projects that will be financed by the package includes geothermal projects totaling $50 \mathrm{MWe}$. A 10-year development plan for the Public Power Corporation, Greece's state utility, includes three major hydro projects and 30 smaller ones to be completed over the next decade. Also to be completed during the next 10 years are windfarms totaling $150 \mathrm{MWe}$, solar projects totaling $1,000 \mathrm{MWe}$, and the geothermal element.

For further information contact Themistoclis Xanthopoulos, General Manager, Public Power Corporation, 30 Halkokondili Street, GR-10432 Athens, GREECE; phone 011-30-1-523-4604; fax 011-30-1-523-9843; telex 21-5643 DEI GR.

Source: Geothermal Resources Council Bulletin 4/93 


\section{NEW EXPLORATION PROJECT UNDERWAY IN JAPAN}

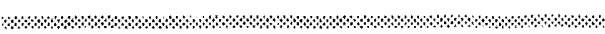

To meet the future demand for electricity, a comprehensive survey of deep-seated geothermal resources beneath conventional geothermal reservoirs 1 3,000-6,400 feet) is underway in Japan. The project was authorized as one of the new Sunshine Projects by the Ministry of International Trade and Industry.

It is a joint project of the New Energy and Industrial Technology Development Organization (NEDO) and the Geological Survey of Japan. NEDO has the ro : of overall project management, and GSJ is to analyze and evaluate the data. A contract was signed on March 31, 1993, with Japan Metals and Chemical Co. to carry out the survey. A deep hole $1 \sim 9,000$ 12,000 feet) is being drilled at the Kakkonda field, which has been commercially produced since 1978, and is expected to be completed by 1995, with various tests and analyses scheduled for 1996-1997.

Source: IGA News 1-3/93

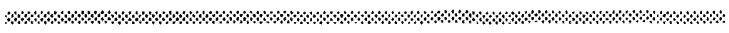

"REMARKABLE" GEOTHERMAL POTENTIAL FOUND IN COSTA RICA

An evaluation of the geothermal potential of Costa Rica by the Costarican Institute of Electricity confirmed "that Costa Rica has a remarkable geothermal potential." The study, conducted from March 1989 to November 1991, found that 33 percent of the country is characterized by "a good to optimum" geothermal occurrence and lends itself to geothermal development. The occurrence in 55 percent of the country ranges from moderate to poor, thus allowing the use of geothermal energy only in direct applications. The electric power potential covers an area extension of about 6,500 square miles.

The installable capacity of the high potential areas, using power plants of one and two separation cycles, is estimated at $2,250 \mathrm{MWe}$ for "resources," or those at a maximum depth of 9,800 feet that can be exploited economically within 25 years, and at 1,000 $\mathrm{MWe}$ for those at a maximum depth of 8,200 feet that can be developed into producing fields in no more than 10 years. The former category is composed of 75 percent of medium- to low-temperature $<150^{\circ} \mathrm{C}\left(<300^{\circ} \mathrm{F}\right)$ fluids and 25 percent high-temperature $>150^{\circ} \mathrm{C}\left(>300^{\circ} \mathrm{F}\right)$ fluids, representing only 0.31 percent of the total heat. The latter category, called "reserves," is composed of 19 percent high-temperature and 81 percent mediumto low-temperature. In total, reserves constitute only 0.20 percent of the total heat. Within the reserve category, it was concluded that:

- The best areas of the country are Miravalles and Rincon de la Vieja, with a potential capacity of about 160 to $190 \mathrm{MWe}$ each.

- The areas of Irazu-Turrialba, Tenorio, Platanar, Poas, and Barva each have a potential of 100 to 115 MWe. 
- The less favorable areas are Fortuna and Orosi-Cacao with a potential of 70 and $35 \mathrm{MWe}$ respectively.

The study conclusions are considered extremely important due to their support of the important role of geothermal energy as a source of energy for Costa Rica in the medium- to long-term.

The study was made possible by the support of the U.N. Fund for Science and Technology for Development and the U.N. Rotary Fund for the Exploration of Natural Resources.

Source: Geothermal Resources Council Bulletin 12/92

\section{POLAND'S FIRST GEOTHERMAL DISTRICT HEATING SYSTEM UNDER CONSTRUCTION}

\% \% \% \%

Construction of the first experimental geothermal district heating plant in Poland, "Banska-Bialy Dunajec," was completed in October 1992. The first part of associated pipeline from the plant to the village of Banska Nizna was just completed in December. This installation is located in the Podhale Basin, 6 miles north of the city of Zakopane and 56 miles south of the city of Cracow.

The project resulted from geological, geophysical, and drilling investigations by the Mineral and Energy Center of the Polish Academy of Sciences. Geothermal resources with good conditions for utilization are found to underlie more than 80,000 square miles of Polish land.
The Podhale region was selected for the pilot project because the geothermal fluid in the Middle Eocene Podhale Basin is $86^{\circ} \mathrm{C}$ $\left(187^{\circ} \mathrm{F}\right)$, of low mineralization, and provides production of up to 68,700 gallons/hour without pump usage and up 132,000 gallons/hour when a deep-well pump is installed. The amount of available heat is enough to cover the heat demand of Zakopane, Nowy Targ, and other villages and small towns located in 190 square miles of the Podhale region.

The Podhale region has the longest heating season in Poland (about 300 days per year) and displays considerable variation of outdoor temperatures from $30^{\circ} \mathrm{C}\left(-80^{\circ} \mathrm{F}\right)$ in winter to $+30^{\circ} \mathrm{C}\left(86^{\circ} \mathrm{F}\right)$ in the summer. Many famous and popular ski resorts as well as recreational areas are located within the Podhale region and Zakopane. Annually about three million tourists visit this region; the population of the town of Zakopane is 35,000 inhabitants. For the last 50 years, Zakopane, Nowy Targ, and other small towns and villages within the Podhale region have been heated by individual stoves or central heating and on a very limited scale by local heat-generating plants, all of them fueled by hard coal or coke. The combustion of these fossil fuels has caused tremendous air and water pollution, creating a health hazard and damaging several national parks. Atmospheric levels of pollutants during the heating season are four times greater than permitted by the applicable air quality standards.

Source: IGA News Oct.-Dec. 92 
1-MWe MODULAR BINARY UNIT STARTS UP IN ITALY

A 1-MWe binary cycle power plant began operation in December 1992 in the ENEL geothermal power station in Castelnuovo near Larderello. The plant is composed of two factory-assembled 43foot modules, one on top of the other. It is microprocessor-controlled and uses a personal computer as an interactive dataacquisition system and supervisor.

The turbogenerator was developed by two Italian companies: Turboden, a small independent company based in Milan, and Sowit (based in Vimodrone) of the large Belleli Group. Turboden supplied the turbine, the controls, and the basic binary technology, with Sowit in charge of the heat exchangers, other process items, and the balance of the plant.

Source: IGA News 11-12/92

\section{GEOTHERMAL POWER EXPANDS}

IN NEW ZEALAND; GENZL GETS LANDMARK GEOTHERMAL SOFTWARE CONTRACT WITH JAPANESE UTILITY

Rotoma, Inc., plans to build a 110-MWe geothermal power plant south of Rotorua City, which will be New Zealand's second privately financed geothermal station. Several small, privately financed geothermal projects are also likely to be built in the near future -- five plants in the 10 to $30 \mathrm{MWe}$ range. Geothermal technological advances have resulted in equipment that can be matched to any possible geothermal project, making geothermal an effective and environmentally friendly entry into the longterm energy market in New Zealand.

The cost for developing geothermal electric generation in New Zealand is among the lowest (1.8 cUS/kWh), comparable with natural gas and lower than coal and hydroelectric. A speaker at an energy conference in the New Zealand capital claimed that geothermal energy could hold the answer for the country's energy future as it faces a possible shortfall in hydroelectricity and natural gas generation potential, and estimated that the potential for additional geothermal generation could be as high as 4,770 MWe.

In other news from New Zealand, Geothermal Energy New Zealand Limited (GENZL) has broken into the highly competitive software market in Japan with a contract worth over NZ $\$ 150,000$ with one of the largest Japanese utilities, Tohoku Electric Power Co. GENZL will supply software, training, and support services to assist the company in increasing the expertise of its geothermal staff. Tohoku, based in the northern part of Honshu Island, has several geothermal fields in its area and is anxious to undertake feasibility studies for power station development at each of them.

For more information, please contact Calum Gunn or Greg Usher, by phone at: 64-9-309-0469 or by fax at 64-9-3093938.

Source: Geothermal Resources Council Bulletin 6-7/93 
WORLD GEOTHERMAL CONGRESS

TO BE HELD IN FLORENCE IN MAY 1995

A World Geothermal Congress will be sponsored by ENEL, Italian Electric Power Company, and convened by the International Geothermal Association (IGA) and co-convened by the Geothermal Resources Council (GRC) May 18-31, 1995. The site of the meeting will be the Centro Congressi in Florence, Italy. The Congress will consist of two days of plenary sessions of invited presentations from various countries that have significant geothermal development, a day of optional excursions, and a final two days of triplesession technical presentations. In addition, there will be a poster session, exhibits of products and services, and short courses. European field trips will be available prior to and following the plenary and technical sessions.

The primary purpose of the World Geothermal Congress 1995 is to provide a forum for international exchange of scientific and technological information on geothermal development during the period 1990-1995. The Congress will generally follow the successful format of the 1975 United Nations International Symposium on Geothermal Energy with presentations of world-wide electrical and direct use, country update reports, international cooperation reports, and invited papers. In addition, contributed technical papers are solicited in all of the following and related areas:

\author{
Exploration and Development \\ Operating Case Histories \\ Drilling Technology \\ Reservoir Evaluation \\ Injection \\ Power Generation \\ Direct Use \\ Advanced Technologies \\ Legal and Institutional Aspects \\ Economics and Financing \\ Environmental Aspects
}

The entire proceedings of the World Geothermal Congress 1995 will be available at the meeting as a hard-bound volume(s).

Supplements to the international and technical programs will include the following:

\section{- fIELD TRIPS}

Field trips in Europe and within Italy will be available May 18-21 and 27-31. A field trip will be offered on Wednesday, May 24. between the plenary and technical sessions. This field trip will visit the nearby geothermal developments in Italy.

\section{- courses}

Short courses will be offered on varied geothermal aspects, both before and after the Congress. Instructors of the short courses will be experts in their fields and will collectively be able to present the state of the art in a particular subject. All attendees will receive a study guide covering course presentations and related material. 


\section{- EXHIBITS}

Full exhibition services will be available prior to and during the meeting. Approximately 50 exhibit booths will be sold on a first-come, first-serve basis. Exhibits will be an important part of the Congress, and the Organizing Committee is focusing on ways to make this function beneficial for both attendees and exhibitors.

\section{- GUEST PROGRAM}

A full guest program will be offered tc all course attendees, families, and friends.

A complete listing of all tours and social activities will be available in a Second Circular that may be obtained by mailing or faxing the following form to:

International Geothermal ASSN.

LBL 50C, Rms 106-108,

One Cyclotron Road

Berkeley, CA 94720, USA

Fax: (510) 486-4889

[PLEASE PRINT CLEARLY OR TYPE]

Name \& Title:

Affiliation:

Address:

City:

Province/State:

Mail Code:

Country:

Telephone:

Fax/Telex:

E-mail: 


\section{TELECONFERENCES PROMOTE USE OF GEOTHERMAL HEAT PUMPS; NEW REPORT CITES ENVIRONMENTAL ADVANTAGES}

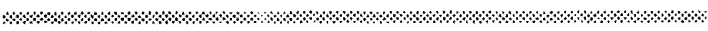

A three-part series of national teleconferences during 1992-93 spotlighting the environmental, economic, and energy-saving benefits of geothermal heat pumps gave the technology, according to an industry spokesman, "credibility and exposure that normally would have taken years to obtain." Many utility and HVAC industry personnel, it was noted, had heard of GHPs, but were unaware that their use had become so prevalent (i.e., at least 150,000 units in operation in all states).

The first teleconference in July 1992 informed utility executives and regulators about recent improvements in GHPs and applications, demonstrated how they have become cost-effective customer options, and confirmed that utility programs to encourage the installation of GHPs as a demand side management tool are a good utility alternative for meeting peak load requirements without increasing capacity. The second teleconference in March 1993 was tailored to dealer/contractors, loop installers, and other trade allies interested in participating in the growing GHP market. The April 1993 teieconference was aimed at architects and engineers and included case studies of successful installations in a variety of building types and climates, as well as guidelines for equipment and sizing for different applications. Each conference reached $3,000-4,000$ people.
The list of teleconference sponsors, which indicates the widespread interest in the technology, included the Electric Power Research Institute, DOE, the Environmental Protection Agency, the Earth Energy Association, the Edison Electric Institute, the International Ground-source Heat Pump Association, the Missouri Department of Natural Resources, and the National Rural Electric Cooperative Association. A video of the teleconferences is available from Policy Research Associates, phone (703) 742-8402.

An EPA report issued in April 1993 estimates that the power generated to provide space conditioning and water heating in residential and commercial buildings represents one of the largest sources of carbon dioxide emissions in the country, comparable to the contribution of all highway transportation, with each segment contributing about 24 percent of the total. When GHPs were evaluated along with other residential HVAC options, they were found to have the greatest potential for reducing $\mathrm{CO}_{2}$ emissions. In addition, refrigerant use -- of concern in atmospheric ozone depletion -- in GHPs is reduced over 50 percent compared with air source heat pumps, since the GHPs are sealed at the factory like a refrigerator or freezer and have no outside compressors or field connections. The EPA report is titled, "Space Conditioning: The Next Frontier -The Potential of Advanced Residential Space Conditioning Technologies for Reducing Pollution and Saving Consumer Money." Copies may be obtained from Michael L'Ecuyer at EPA at (202) 2339127. 


\section{GEOTHERMAL RESOURCES COUNCIL ANNUAL MEETING FOCUSED ON UTILITIES}

With "Utilities and Geothermal: An Emerging Partnership" as its theme, the 1993 Geothermal Resources Council annual meeting was held in Burlingame, California, October 10-13. There were 740 attendees, representing 17 countries including the United States.

At a special utility/geothermal partnership session, the impact of utility demand side management on the geothermal industry was considered, and utility forecasts of the viability of "qualifying facilities" in the "Year 11" (see related article in INDUSTRY SCENE) were presented. Another timely discussion was the "Special Reduced-Cost Exploration Session" on the economics and effectiveness of slim-hole drilling and other techniques for exploration that would avoid the high cost of production-size wells.

Pre-meeting workshops were held on TETRAD geothermal reservoir simulation, advances in binary cycle power systems, and geothermal development on Federal lands. Post-meeting tours to The Geysers with an optional overnight stay in the city of Calistoga were also offered.

\section{SCOPE AND POWER OF TOUGH2 RESERVOIR SIMULATOR BEING ENHANCED}

TOUGH2 is the most recent in the Lawrence Berkeley Laboratory family of multiphase geothermal reservoir simulation codes. Its capabilities include simulation of the following:

- Multiphase, multicomponent fluid and heat flow,

- Phase change (boiling and condensation),

- Porous media and naturally fractured reservoirs,

- Flexible fluid production and injection specifications, and

- One-, two-, and three-dimensional regular or irregular geometry.

Several new modules that substantially enhance the scope and power of TOUGH2 are in various stages of development, and will be released to the public through the Energy Science and Technology Software Center in Oak Ridge, Tennessee -- where TOUGH2 and its predecessor TOUGH are currently available, following completion of testing with the participation of major DOE contractors.

The TOUGH and TOUGH2 codes have become the most widely used software packages of their kind, nationally and internationally, and are used by approximately 100 organizations 
worldwide. In addition to their role in geothermal and environmental applications, they are applicable to nuclear waste isolation projects as well. In their commercial geothermal use, it is reported that just one of the companies using TOUGH/TOUGH 2 has performed in excess of 25 field simulation studies with the codes, with a combined service value of several million dollars.

For technical information, contact Karsten Pruess, Mail Stop 50E, Lawrence Berkeley Laboratory, Berkeley, CA 94720.

Source: Lawrence Berkeley Laboratory

$\% \% \% \% \% \% \% \%$

GEOTHERMAL DISTRICT HEATING SYSTEMS MOST FUEL EFFICIENT DH SYSTEMS IN OPERATION TODAY, ASHRAE TO BE TOLD

In a paper prepared for delivery to the 1994 Winter Meeting of the American Society for Heating, Refrigeration, and Air Conditioning Engineers (ASHRAE), Kevin Rafferty of the Geo-Heat Center notes that "geothermal energy currently provides a stable and environmentally attractive heat source for approximately 20 district heating (DH) systems in the U.S." The abstract of the paper, which is titled "Environmental Considerations for Geothermal Energy as a Source for District Heating Systems," concludes that:

"The use of this resource eliminates 100 percent of the conventional fuel consumption (and hence, the emissions) of the loads served by these systems. As a result, geothermal DH systems can rightfully claim the title of the most fuel efficient $D H$ systems in operation today.

"Costs for producing heat from a geothermal resource (including capitalization of the production facility and cost for pumping) amount to an average of $\$ 1.00$ per million Btu. The major environmental challenge for a geothermal system is proper management of the producing aquifer. Many systems are moving toward injection of the geothermal fluids to assure long term production."

The ASHRAE meeting will be held in New Orleans on January 22-26, 1994.

\section{ASHRAE UNDERTAKES TO DEFINE GEOTHERMAL HEAT PUMP TERMINOLOGY}

A technical committee of the American Society of Heating, Refrigeration, and Air Conditioning Engineers has undertaken to develop a consensus set of terms to define the various GHP technologies that can be used by major interested groups. An interim version incorporating committee numbers' comments include:

Ground-source Heat Pump: A heat pump system employing the earth's surface water or groundwater as a heat source/sink including ground-coupled and groundwater source systems. 
Groundwater Heat Pump System: Heat pump system in which surface water or groundwater is physically delivered to and from the heat pump for the purpose of serving as a heat source/sink. Often referred to as an open-loop system.

Ground-Coupled Heat Pump System: Heat pump systems in which a closed loop of piping containing a heat transfer liquid or refrigerant serves to transfer heat between the heat pump and the ground, groundwater, or a body of surface water serving as the heat source/sink. Often referred to as a closed-loop system.

Source: Geo-Heat Center Quarterly Project Progress Report 10-12/92 


\section{MAJOR SOURCES OF GEOTHERMAL INFORMATION}

This section of the GPM presents a representative sample of geothermal literature that has been reported since the last issue. Wider coverage of the literature may be found in a bimonthly publication of current abstracts, titled "Geothermal Energy," published by DOE's Office of Scientific and Technical Information. The publication may be obtained from the National Technical Information Service, Springfield, VA 22161 as PB 88-914700. The annual subscription price for six issues is $\$ 90.00$ (domestic) and $\$ 180.00$ (outside the North American continent). The publication typically lists each paper, article, or report derived from another publication, such as conference proceedings, as a separate entry. Space does not permit separate listings in the GPM; thus, the following are recommended:

Geothermal Resources Council Bulletin, Monthly Publication of GRC, P.O. Box 1350, Davis, California 95617-1350

Geothermal Resources Council Transactions, Proceedings, GRC Annual Meetings

Stanford University Annual Workshop on Geothermal Reservoir Engineering, Stanford Geothermal Program, Dept. of Petroleum Engineering, Stanford, California 94305

Proceedings of the Annual Geothermal Program Review, Geothermal Division, U.S. Department of Energy. Available from the National Technical Information Service, U.S. Department of Commerce, Springfield, Virginia 22161 (No. X March 24-26, 1992, No. XI April 27-28, 1993)

Annual Geothermal Energy Program Summary, Volumes 1 and 2, U.S. Department of Energy

The Geothermal Hot Line, California Division of Oil and Gas, 801 K Street, 20th Floor, Sacramento, California 95814-3530

Geothermics, International Journal of Geothermal Research and Its Applications, Pergamon Press Inc., Maxwell House Fairview Park, Elmsford, New York 10523

American Society of Mechanical Engineers, International Joint Power Generation Conference, Atlanta, Georgia. (October 18-22, 1992)

American Mineralogist

Geochimica et Cosmochimica Acta, U.S. Publication 
Proceedings, International Conference on Industrial Uses of Geothermal Energy, Reykjavik, Iceland, September 2-4, 1992

Energy for the Transition Age: Flowers '92, Proceedings of the Florence, Italy, World Energy Research Symposium, June 7, 1992

Chishitsu Chosajo Hokoku, Report, Geological Survey of Japan, No. 279, August 31, 1992

Butsuri Tanko (Geophysical Exploration), Japan, June 1992

NOTE: Copies of the publications listed below should be obtained from NTIS at the address provided at the beginning of this article, or from one of the other sources listed. Those marked "GPO Dep." are available for inspection or interlibrary loan at Government Printing Office regional depository libraries. DOE and DOE contractors may order from the DOE Office of Scientific and Technical Information (OSTI), P. O. Box 62, Oak Ridge, TN 37831. Where given, the "GPO Dep. Order No." is the accession number for all locations; an NTIS number only is given when the document is not available at GPO. ITIS is the Integrated Technical Information System maintained by OSTI for contractor accession to DOE online databases.

\section{RESOURCE STATUS AND ASSESSMENT}

Gosnold, W.D., Jr. (comp.), Geothermal Resources of South Dakota, North Dakota Mining and Mineral Resources Research Institute; North Dakota Geological Survey, OSTI; NTIS; GPO Dep. Order No. DE92017535 (1992).

Duchane, D.V. and F. Goff, "Prospects for the Commercial Development of Hot Dry Rock Geothermal Energy in New Mexico," Los Alamos National Laboratory, from New Mexico Conference on the Environment: Toward a Sustainable Environment, OSTI; NTIS; GPO Dep. Order No. DE92018999 (1992).

New Energy and Industrial Technology Development Organization, FY1990 Annual Report of Geothermal Energy Survey and Technology, Tokyo, Japan, OSTI; NTIS Order No. DE93716356 (1992).

Jones, F.W., The Temperature Regime of the Western Canada Sedimentary Basin: The Influence of Hydrodynamics and the Potential for Geothermal Energy Resources from the Sediments, Alberta University, Solar Energy Society of Canada, 420-30, Moodie Drive, Nepean, ON, CAN K2H 9 C4 Price $\$ 35.00$ CAN, CONF-920764 (1992).

McKenzie, D.I., Ground Water Heat Pump Suitability Mapping: Theory, Procedure, and Assessment, University of Western Ontario, MF Micromedia Ltd., Technical Information 
Center, 165 Hotel de Ville, Place du Portage, Phase 2, Hull, Quebec, CA J8X 3X2, Price $\$ 15.00$ CAN (May 1988).

Agency of Industrial Science and Technology, Japan's Sunshine Project, Tokyo, OSTI; NTIS Order No. DE93768268 (July 1992).

Petty, S., et al., Supply of Geothermal Power from Hydrothermal Sources: A Study of the Cost of Power in 20 and 40 Years, Sandia National Laboratories and consultants, OSTI; NTIS; GPO Dep. Order No. DE93004479 (Nov. 1992).

Kenya Geothermal Private Power Project: A Prefeasibility Study, National Geothermal Assn.; Davis, CA, OSTI; NTIS, INIS; GPO Dep. Order No. DE93002274 (Oct. 1992).

Meckler, M., "Geothermal Power Development," in Innovative Energy Design for the '90s, Fairmont Press, Inc., Lilburn, GA (1993).

Dimitrow, K., et al., "Geothermal Energy Resources and their Use in Yugoslavia," Energy Sources, 15: No. 1 (Jan.-March 1993).

\section{GEOLOGY AND HYDROLOGY OF GEOTHERMAL SYSTEMS}

Parker, R.H., "Progress with the Development of Hot Dry Rock Geothermal Energy at the Cambourne School of Mines," Energy and the Environment: Into the 1990's, World Renewable Energy Congress, v.5. Sayigh, A.A.M. Oxford (GB); Pergamon Press, CONF-900901 (1990).

Giggenbach, W.F. and R.C. Soto, "Isotopic and Chemical Composition of Water and Steam Discharges from Volcanic-Magmatic-Hydrothermal Systems of the Guanacasti Geothermal Province, Costa Rica," Applied Geochemistry (United Kingdom); 7: No. 4 (July 1992).

Delaney, J.R., et al., "Geology of a Vigorous Hydrothermal System on the Endeavor Segment, Juan de Fuca Ridge," Journal of Geophysical Research; 97: No. B13 (Dec. 10, 1992).

White, R.S., et al., "Oceanic Crustal Thickness from Seismic Measurements and Rare Earth Element Inversions," Ibid.

Experimental and Theoretical Investigation of the Production of $\mathrm{HCl}$ and Some Metal Chlorides in Magmatic/Hydrothermal Systems, Maryland University, Dept. of Geology, OSTI; NTIS; GPO Dep. Order No. DE93008761 (1992). 


\section{GEOTHERMAL EXPLORATION AND EXPLORATION TECHNOLOGY}

West, H.B., et al., Trace Elements and Isotope Geochemistry of Geothermal Fluids, East Rift Zone, Kilauea, Hawaii, Hawaii University, OSTI; NTIS; GPO Dep. Order No. DE92014586 (1992).

International Atomic Energy Agency, Geothermal Investigations with /sotope and Geochemical Techniques in Latin America, OSTI; NTIS (U.S. Sales Only); INIS Order No. DE92633881 (March 1992).

Finger, J.T. and R.D. Jacobson, Phase 2 Drilling Operations at the Long Valley Exploratory Well (LVF 51-20), Sandia National Laboratories, OSTI; NTIS; GPO Dep. Order No. DE92017350 (June 1992).

Barbier, J., World Review of High Enthalpy Geothermics. Exploration Methods, Realizations, and Prospectives, International Geothermal Assn., Agence Francaise pour la Matrise de I'Energie, Paris, OSTI; NTIS (U.S. Sales Only) Order No. DE93706805 (1990).

Egbert, G.D., New Approaches to Estimation of Magnetotelluric Parameters, Oregon State University Co'ıege of Oceanography, OSTI; NTIS; GPO Dep. Order No. DE92040280 (1991).

Kiryukhin, A.V. Progress Report on Modeling Studies: Natural State Conditions and Exploitation of the Dachny Hydrothermal System, Kamchatka, Russia, Lawrence Berkeley Laboratory, OSTI; NTIS; GPO Dep. Order No. DE93001586 (July 1992).

Carrigan, C.R., et al., "Triaxial Thermopile Array Geo-Heat-Flow Sensor," U.S. Patent No. 5, 121, 993/A/, Patent and Trademark Office, Box 9, Washington, DC 20232, to U.S. Department of Energy (June 16, 1992).

Dennis, B., et al., Closed-loop Flow Test Miravelles Geothermal Field Well Log Results, Los Alamos National Laboratory, OSTI; NTIS; GPO Dep. Order No. DE93001360 (1992).

Keeley, D.F., A Study of Hydrocarbons Associated with Brines from DOE Geopressured Wells, University of Southwestern Louisiana, Acadiana Research Laboratory, OSTI; NTIS; GPO Dep. Order No. DE93005643 (1992).

New Energy and Industrial Technology Development Organization, Survey on Deep Seated Geothermal Resource Drilling and Production Technology, OSTI; NTIS Order No. DE93768471 (March 1992). 
Delprat-Jannoud, F. and P. Lailly, "What Information on the Earth Model Do Reflection Travel Times Provide?" Journal of Geophysical Research; 97: No. B13 (December 10, 1992).

Hirn, A. and S.A. Magnier, "Shear Source Multiazimuth Near-and Far- Offset Vertical Seismic Profiles, Asal Rift, Republic of Djibouti," Ibid.

\section{ECONOMIC, INDUSTRIAL, AND BUSINESS ASPECTS}

Walter, R., "Geothermal Energy: A Great Alternative," Proceedings, GLOBALCON '92, Association of Energy Engineers Conference and Exposition on Energy and the Environment, CONF-920344 (1992).

Tester, J.W. and H.J. Herzog, "The Economics of Heat Mining: An Analysis of Design Options and Performance Requirements of Hot Dry Rock (HDR) Geothermal Power Systems," Energy, Systems and Policy, 15: No. 1 (1991).

Molarty, L. and M.J. Reed, "The U.S. Geothermal Industry: Three Decades of Growth," Energy Sources, 14: No. 4 (October 1992).

National Geothermal Association Trade Mission to Central America, National Geothermal Association, Davis, CA, OSTI; NTIS; INIS; GPO Dep. Order No. 93002272 (October 1992).

Yamada, Y., "Current Status and Future Prospects of Geothermal Energy Development," Global Environment Protection Strategy Through Thermal Engineering, Hemisphere Publishing, New York (1992).

Anderson, J.W., "Geothermal in Transition," Independent Energy; 21: No. 8 (October 1991).

"Geothermal, Section 2: Products and Services," Ibid., 21: No. 10 (December 1991).

Short, W.P., "Geothermal Status Report," Independent Energy; 22: No. 8 (October 1992).

Haraden, J., "Cost-benefit Analyses for the Development of Magma Power, "Energy Economics (Oxford) (United Kingdom); 14: No. 4 (October 1992).

\section{ENVIRONMENTAL ASPECTS}

John, C.J., Geopressured-geotherma/ Well Activities in Louisiana, Louisiana Geological Survey, OSTI; NTIS; INIS; GPO Dep. Order No. DE93002865 (October 1992). 
New Energy and Industrial Technology Development Organization, Summary Report on the Present Status of Geothermal Development and the Environment, Tokyo, OSTI, NTIS Order No. DE93768473 (March 1992).

\section{GEOTHERMAL POWER PLANTS}

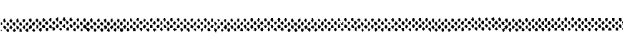

Lisong Zhe and Ju Qi, "Experimental Research and Development of Geothermal Energy Utilization in China," Energy and the Environment: Into the 1990's, World Renewable Energy Congress, v.5 Sayigh, A.A.M. Oxford (GB); Pergamon Press, CONF-900901 (1990).

Tokeley, A.H. and D.P. Brown, "Ohaaki Power Station: Geothermal Development in New Zealand," Proceedings of the Institution of Mechanical Engineers, Part A, Journal of Power and Energy, (United Kingdom) 206: No. A-1 (1992).

Moinanty, B. and G. Paloso, Jr., "Economic Power Generation from Low-Temperature Geothermal Resources Using Organic Rankine Cycle Combined with Vapor Absorption Chiller," Heat Recovery Systems and CHP (United Kingdom); 12: No. 2 (March 1992).

Documentation of the Status of International Geothermal Power Plants and a List by Country of Selected Geothermally Active Governmental and Private Sector Entities, National Geothermal Assn., Davis, CA, OSTI; NTIS; INIS; GPO Dep. Order No. DE93002273 (October 1992).

\section{GEOTHERMAL ENGINEERING}

\%ం\% $\% \% \% \%$

Kukacka, L.E., Materials for Geothermal Production, Brookhaven National Laboratory, OSTI; NTIS; GPO Dep. Order No. DE92014691 (1992).

Ibid., Geothermal Materials Development, DE92016940 (December 1991).

Carter, J.P. and S.D. Cramer, Materials of Construction for High-Salinity Geothermal Brines. Rept. of Investigations/1992, Bureau of Mines, Albany, Oregon, BUMINES - RI-9402; NTIS Prices: PC AO3/MF AO1 (May 1991).

Loeppke, G.E., et al., Development and Evaluation of a Meter for Measuring Return Line Fluid Flow Rates During Drilling, Sandia National Laboratories, OSTI; NTIS; GPO Dep. Order No. DE92017352 (June 1992). 
Duchane, D.V., "Hot Dry Rock Heat Mining: An Advanced Geothermal Energy Technology," Proceedings of Emerging Energy Technology. American Society of Mechanical Engineers, CONF-920122 (1992).

Hasan, A.R. and C.S. Kabir, "Determination of Static Reservoir Temperature from Transient Data Following Mud Circulation," Proceedings, Society of Petroleum Engineers, Western Regional Meeting, CONF-920383 (1992).

Kutasov, I.M., "Program Predicts Reservoir Temperature and Geothermal Gradient," Oil and Gas Journal, 90: No. 22 (June 1, 1992).

Gallup, D.L. and J.L. Featherstone, "Treatment of Geothermal Brine," U.S. Patent 5,098,578/A/, Patent and Trademark Office, Box 9, Washington, DC 20232, to Union Oil Co. of California (March 1992).

Ross, H.P. and C.K. Forsgren Eds.), Salton Sea Scientific Drilling Project: A Summary of Drilling and Engineering Activities and Scientific Results, University of Utah Research Institute, Salt Lake City, OSTI; NTIS; GPO Dep. Order No. DE92019388 (April 1992).

Stanford Geothermal Program Quarterly Technical Report, January-March 1992, Stanford University, OSTI; NTIS; GPO Dep. Order No. 92040143 (May 12, 1992).

Bertini, L. and P. Conti, "Fatigue Crack Growth Behavior of Four Structural Steels in Air and in a Geothermal Fluid Environment," International Journal of Fatigue (United Kingdom), 14: No. 2 (March 1992).

Zhao, J. and E.T. Brown, "Thermal Cracking Induced by Water Flow Through Joints in Heated Granite," International Journal of Rock Mechanics and Mining Sciences and Geomechanics Abstracts (United Kingdom), 29: No. 1 (January 1992).

Lam, L., et al., "Developments in Geothermal Energy in Mexico: Pt. 38: Heat Transfer Assessment of a Geothermal Steam Gas Removal Reboiling Process," Heat Recovery Systems and CHP (United Kingdom), 12: No. 2 (March 1992).

Siqueiros, J., et al., "Pt. 39: Extraction of Useful Heat and Silica Removal from Geothermal Brine Utilizing Liquid Fluidized Bed Heat Exchangers." Ibid.

Lienau, P.J., Data Acquisition for Low-temperature Geothermal Well Tests and Long-term Monitoring, Geo-Heat Center, Oregon Institute of Technology, OSTI; NTIS; GPO Dep. Order No. DE9300387 (September 1992). 
Aromatic Hydrocarbons Associated with Brines from Geopressured Wells, University of Southwestern Louisiana, Acadiana Research Laboratory, OSTI; NTIS; GPO Dep. Order No. DE93000933 (September 1992).

Parker, R.H. (Ed.), Cambourne Geothermal Energy Project Techniques for the Improvement of the Hydraulic Performance of HDR Reservoirs, Cambourne School of Mines, United Kingdom, OSTI; NTIS (U.S. Sales Only) Order No. DE93760825 (1992).

Jupe, A.J., et al., "Induced Microseismicity and Reservoir Growth at the Fjellbacka Hot Dry Rock Project, Sweden," International Journal of Rock Mechanics and Mining Sciences, 29: No. 4 (1992).

Mumma, D.M., Explosive Stimulation of a Geothermal Well: GEOFRAC, Los Alamos National Laboratory, Physics International Co., San Leandro, CA, OSTI; NTIS; GPO Dep. Order No. DE93010758 (July 1992).

Wallroth, T., Hydraulically Induced Failures and International HDR Activities, Swedish National Board for Industrial and Technical Development, Chalmers University, Goeteborg, Sweden, OSTI; NTIS, Order No. DE93769994 (1991).

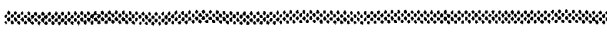

\section{DIRECT ENERGY UTILIZATION}

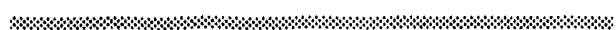

Geo-Heat Center, Geothermal Direct-Heat Utilization Assistance, Oregon Institute of Technology, OSTI; NTIS; GPO Dep. Order No. DE92041079 (1992).

Rafferty, K., "Geothermal District Heating: A Century of Service," ASHRAE Journal (American Society of Heating, Refrigerating, and Air-Conditioning Engineers), 34: No. 9 (September 1992).

Piatti, A., et al., Planning of Geothermal District Heating Systems, Netherlands, Kluwer Academic Publishers, 101 Philip Drive, Norwell, MA 02061, EUR-13772-EN (1992).

"Geothermal Heat Pump Benefits," Energy Digest (United Kingdom), 21: No. 4 (1992).

Chih Wu, "Cooling Capacity Optimization of a Geothermal Adsorption Refrigeration Cycle," International Journal of Ambient Energy (United Kingdom), 13: No. 3 (July 1992).

Rafferty, K. . Direct Use Geothermal Applications for Brazed Plate Heat Exchangers, Geo-Heat Center, Oregon Institute of Technology, OSTI; NTIS; GPO Dep. Order No. DE93007149 (1992). 
Manghnani, M.H., Physical Characterization of Magmatic Liquids, Hawaii University Dept. of Geology and Geophysics, OSTI; NTIS; GPO Dep. Order No. DE92015302 (June 1992 ).

Behl, R.J., et al., "Field Classification and Oxygen Isotope Composition of Quartz Cherts from the Monterey Formation, Santa Maria Basin, California," AAPG Bulletin (American Association of Petroleum Geologists), 75: No. 2 (February 1991).

Barker, C.E., "Implications for Organic Maturation Studies of Evidence for a Geologically Rapid Increase and Stabilization of Vitrinite Reflectance at Peak Temperature: Cerro Prieto Geothermal System, Mexico," Ibid., 75: No. 12 (December 1991).

Experimental and Theoretical Investigation of the Production of HCl and Some Metal Chlorides in Magmatic/Hydrothermal Systems, Maryland University, OSTI; NTIS; GPO Dep. Order No. DE93000308 (1990).

(bid., GPO Dep. Order No. DE93000310 (1991).

Richards, H.G., et al., "Granite-water Reactions in an Experimental Hot Dry Rock Geothermal Reservoir, Rosemanowes Test Site," Applied Geochemistry (United Kingdom), 7: No. 3 (May 1992).

Savage, D., et al., "Granite-water Interactions in a Flow-through Experimental System with Applications to the Hot Dry Rock Geothermal System at Rosemanowes, Cornwell, U.K., Ibid.

Pauwels, H.P., et al., "Water-rock Interactions During Experiments Within the Geothermal Hot Dry Rock Boreholes GPKI, Soultz-sous-Forets, Alsace, France," Ibid.

Kohl, T., et al., Modelling of Coupled Hydraulic Thermal and Mechanical Processes in the Simuiation of Hot Dry Rock Reservoir Behavior, Bundesamt fuer Energiewirtschaft, Bern, ENET Administration und Versand, Postfache 142, CM3000, Bern 6, Switzerland (1992).

Osadetz, K.G., et al., "Thermal History of the Cordilleran Foreland Basin in Western Canada," in Foreland Basins and Fold Belts, American Assn. of Petroleum Geologists, Tulsa (1992).

Goff, F., et al., Geochemistry of Thermal/Mineral Waters in the Clear Lake Region, California, and Implications for Hot Dry Rock Geothermal Developrnent, Los Alamos National Laboratory, OSTI; NTIS; GPO Dep. Order No. DE93007458 (February 1993). 
MISCELLANEOUS

Brower, M., "Geothermal Energy," Cool Energy, Renewal Solutions to Environmental Problems, Massachusetts Institute of Technology Press (1992).

Harrison, R., "Applications of Geothermal Energy," Endeavcurs (United Kingdom), 16: No. 1 (1992). 
U.S. Department of Energy Geothermal Division, EE-122 1000 Independence Ave., SW Washington, DC 20585

Phone (202) 586 - (ext.)

Robert L. San Martin

Roland R. Kessler

John E. Mock

Allan J. Jelacic

David B. Lombard

Stanley D. Calvert

Raymond Fortuna

Gladys J. Hooper

Raymond J. LaSala

Lew W. Pratsch

Marshall Reed
9275

8089

5340

6054

4952

$1, \ldots$

1146

4198

1512

8076
Deputy Assistant Secretary, Office of Utility Technologies

Director, Office of Renewable Energy Conversion

Director, Geothermal Division

Team Leader Geosciences Research

Team Leader, Energy Applications

Manager, Direct Use

Manager, Geopressured Resources

Manager, Advanced Brine Chemistry, Hot Dry Rock, Long Valley Exploratory Well

Manager, Heat Cycle Research, Materials

Manager, Drilling Research, Geothermal Heat Pumps

Manager, Hydrothermal Reservoir Technology 
U.S. Department of Energy

Albuquerque Field Office

P. O. Box 5400

Albuquerque, NM 87112
U.S. Department of Energy

Golden Field Office

1617 Cole Boulevard

Golden, CO 80401

U.S. Department of Energy

Idaho Field Office

785 DOE Place

Idaho Falls, ID 83402
George P. Tennyson, Jr. Senior Program Manager (505) 845-4256

Nyles Lackey

Energy Project Manager (505) 845-4257

Dan Sanchez

Energy Project Manager

(505) 845-4417

Robert L. Martin

Senior Project Manager

(303) 275-4763

Jeffrey Hahn

Geothermal Project Manager

(303) 275-4775

Peggy Brookshier

Senior Program Manager

(208) 526-1403

Robert Creed

Geothermal Project Manager

(208) 526-9063

\section{NATIONAL LABORATORIES (GEOTHERMAL PRINCIPAL INVESTIGATORS)}

Brookhaven National Laboratory

Process Materials Group

Upton, NY 11973
Building 526

Lawrence E. Kukacka

Advanced Materials Research

(516) 282-3065

Eugene T. Premuzic

Biochemical Processes

(516) 282-2893

Joel Renner

Idaho National Engineering Laboratory

Hydrothermal Reservoir Technology (208) 526-9824 
Ben Rinehart

Geopressured Resources

(208) 526-1002

Greg Mines

Energy Conversion

(208) 528-0260

Lawrence Berkeley Laboratory

Marcelo J. Lippmann

Earth Sciences Division

Building 50E

Reservoir Research

Berkeley, CA 94720

(510) 486-5035

Los Alamos National Laboratory

P. O. Box 1663, MS-D443

David V. Duchane

Los Alamos. NM 87545

Hot Dry Rock Research

(505) 667-9893

National Renewable Energy Laboratory

John V. Anderson

1617 Cole Boulevard

Energy Conversion

Golden, CO 80401

(303) 231-1022

Sandia National Laboratoaries

P. O. Box 5800, Division 6252

James C. Dunn

Albuquerque, NM 87185

Drilling R\&D; Long Valley Exploratory

Well; Geothermal Drilling Organization (505) 844-4715

\section{STATE GEOTHERMAL CONTACTS}

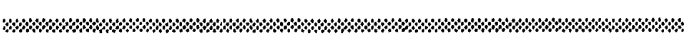

STATE

NAME

ARIZONA

CALIFORNIA
Frank Mancini

Arizona Department of Commerce Energy Office

Solar and Energy Engineering 3800 North Central

Suite 1200

Phoenix, AZ 85012

Kelly Birkinshaw

California Energy Commission

1516 Ninth Street - MS-43

Sacramento, CA 95814

\section{PHONE NUMBER}

Tel: (602) 280-1440

Fax: (602) 280-1445

Tel: (916) 654-4542

Fax: (916) 654-4676 


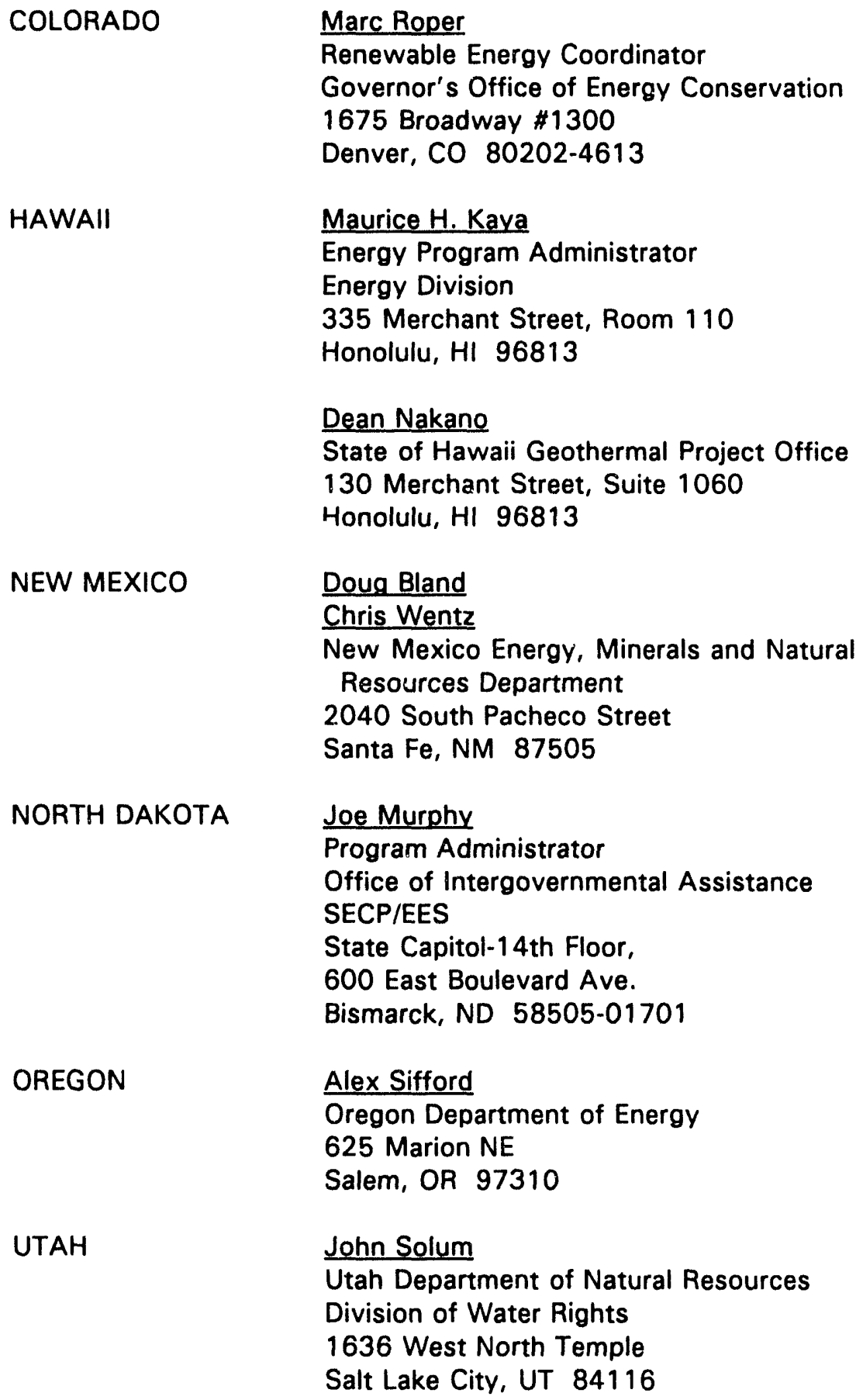

Renewable Energy Coordinator

Governor's Office of Energy Conservation 1675 Broadway \#1300

Denver, CO 80202-4613

Maurice H. Kaya

Energy Program Administrator

Energy Division

335 Merchant Street, Room 110

Honolulu, HI 96813

Dean Nakano

State of Hawaii Geothermal Project Office 130 Merchant Street, Suite 1060

Honolulu, HI 96813

\section{Doug Bland}

Chris Wentz

New Mexico Energy, Minerals and Natural

Resources Department

2040 South Pacheco Street

Santa Fe, NM 87505

Joe Murphy

Program Administrator

Office of Intergovernmental Assistance

State Capitol-14th Floor, 600 East Boulevard Ave.

Bismarck, ND 58505-01701

Alex Sifford

Oregon Department of Energy

625 Marion NE

Salem, OR 97310

John Solum

Utah Department of Natural Resources

Division of Water Rights

1636 West North Temple

Salt Lake City, UT 84116

Tel: $\quad$ (303) 620-4292

Fax: (303) 620-4288

Tel: (808) 587-3812

Fax: (808) 587-3820

Tel: (808) 586-2353/4

Fax: (808) 586-2536

Tel: $\quad(505) 827-5950$

Fax: (505) 438-3855

Tel: (701) 224-2094

Fax: (701) 224-2308
Tel: (503) 378-2778

Fax: (503) 373-7806

Tel: (801) 538-7406

Fax: (801) 538-7315 
STATE

ALASKA

CALIFORNIA

IDAHO

MONTANA
NAME

Roman Motyka

Department of Natural Resources

Division of Geological and

Geophysical Surveys

400 Willoughby Avenue

Juneau, AK 99801

Don Turner

University of Alaska

Geophysical Institute

Fairbanks, AK 99775-0800

Eugene Wescott

Geophysical Institute

University of Alaska

P.O. Box 757320

Fairbanks, AK 99775-7320

Richard Thomas

California Division of Oil \& Gas

Geothermal Section

801 K Street, MS 21

20th Floor

Sacramento, CA 95814-3530

Rick Sterling

Idaho Department of Water Resources 1301 North Orchard, Statehouse Mail

Boise, ID 83720

Montana Department of Natural

Resources and Conservation

Energy Division

1520 6th Avenue, $E$

Helena, MT 59620-2301

Bill Sill

Hydrothermal Division

Montana College of Mineral

Science and Technology

Butte, MT 59701

\section{PHONE NUMBER}

Tel: (907) 465-2520

Fax: (907) 586-3113

Tel: $\quad$ (907) 474-7576

Tel: $\quad$ (907) 474-7198

Fax: (907) 474-7290

Tel: (907) 474-7576

Fax: (907) 474-7290

Tel: $\quad(916) 323-1787$

Fax: (916) 323-0424

Tel: (208) 327-7961

Fax: (208) 327-7866

Tel: $\quad$ (406) 444-6697

Tel: (406) 496-4209

Tel: (406) 496-4211 
Chuck Widemand

Hydrothermal Division

Montana College of Mineral

Science and Technology

Butte, MT 59701

NEVADA

NEW MEXICO

OKLAHOMA

OREGON

UTAH

WASHINGTON

\section{Dennis Trexler}

Division of Earth Science

100 Washington Street, Suite 201

Reno, NV 89503

Rudi Schoenmackers

Southwest Technology

Development Institute

New Mexico State University

P. O. Box 30001

Department 3-SOL

Las Cruces, NM 88003-001

Ken Luza

Oklahoma Geological Surve'v

University of Oklahoma

100 E. Boyd, Room N-131

Norman, OK 73019-0628

George Priest

Oregon Department of Geology

and Mineral Industries

800 NE Oregon Street, \#28

Suite 965

Portland, OR 97232

Robert Blackett

Utah Geological Survey

2363 S. Foothill Drive

Salt Lake City, UT 84109

Eric Schuster

Department of Natural Resources

Division of Geology and Earth Resources

P. O. Box 47007

Olympia, WA 98504-7007
Tel: (406) 496-4209

Tel: (406) 496-4211

Tel: (702) 784-6151

Fax: (702) 784-4549

Tel: (505) 646-1846

Fax: (505) 646-2960
Tel: (405) 325-3031

Fax: (405) 325-3180

Tel: (50)3) 731-4100

Fax: (503) 731-4066
Tel: (801) 467-7970

Fax: (801) 467-4070

Tel: (206) 902-1451

Fax: (206) 902-1785 

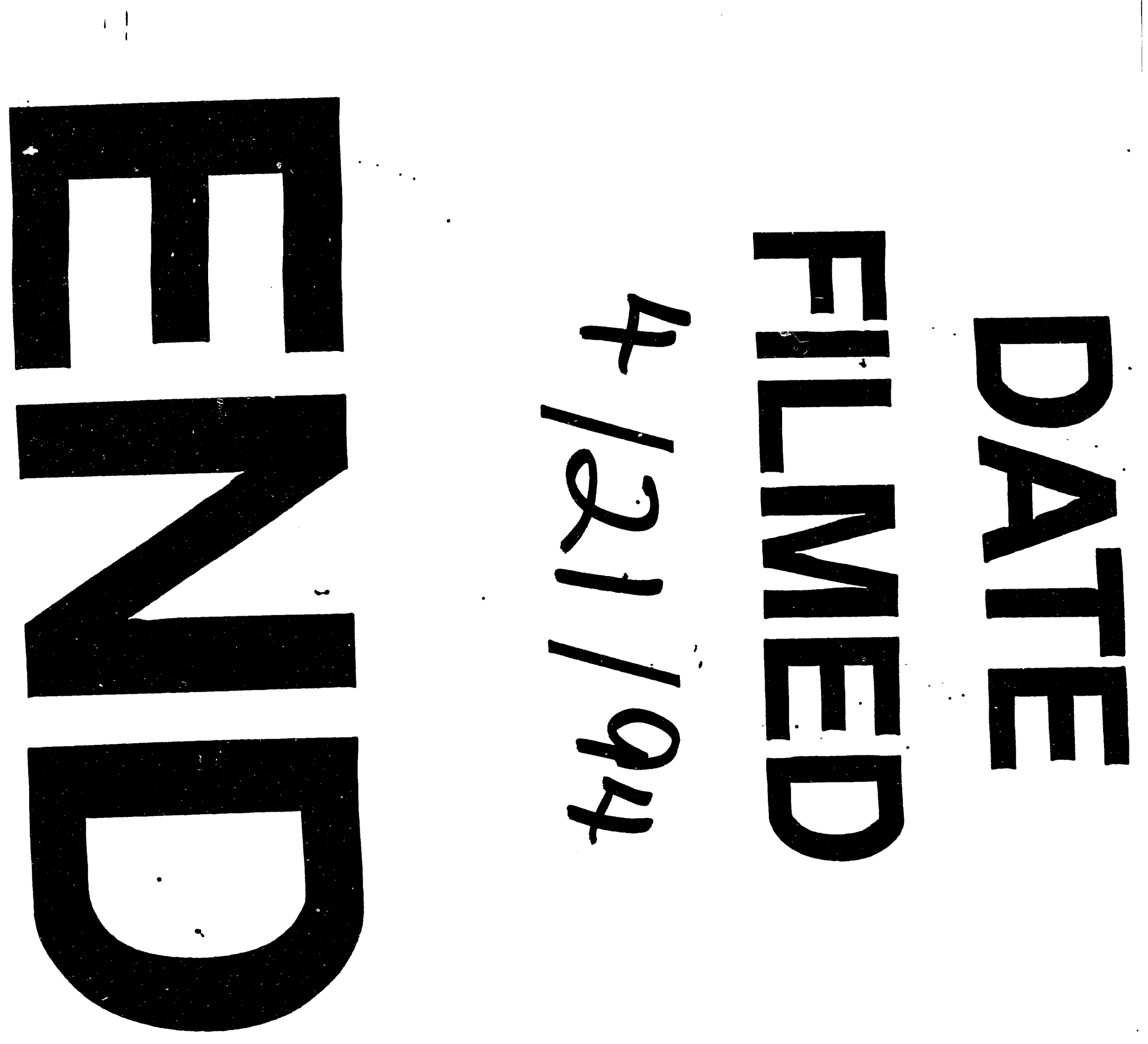
